\title{
Los pleitos plenos de hidalguía en la Baja Edad Media: una posible evolución jurídica bajo los Trastámara desde la óptica de la Edad Moderna*
}

\author{
The nobleman lawsuits in the Late Middle Ages: \\ a possible legal evolution during the trastamara dynasty \\ under the Modern Age point of view
}

\author{
LUIS DíaZ dE LA GuARDia y LÓPEZ**
}

\begin{abstract}
RESUMEN
Mediante el estudio de las leyes medievales recopiladas en tiempos del rey Felipe II y a través de documentación de los siglos XIV al XVII, se realiza un análisis de los principales eslabones normativos de la Baja Edad Media castellana que dieron consistencia al denominado pleito de Hidalguía. Es la crónica de una evolución legislativa en busca del dominio regio de este tipo procesal y que tendrá como punto de llegada y de partida la ley de 1492 de los Reyes Católicos: punto de llegada para la Edad Media, punto de partida para la Edad Moderna. Pero el presente artículo no se limita a la descripción, sino a contextualizar las diferentes leyes medievales y también a buscar conclusiones referentes a sus aciertos y a sus carencias. Cosas, ambas, que se mantendrían desde el Medievo hasta el fin del Antiguo Régimen, pese a los deseos de reyes, legisladores y jueces.
\end{abstract}

\begin{abstract}
By means of the study of medieval laws compiled in times of King Philip II and through documentation of the 14th to 17th centuries, an analysis of the main normative links of the Castilian Early Middle Ages that gave consistency to the so-called lawsuit of nobility is conducted. It is the chronicle of a legislative evolution in search of the royal dominion of this procedural type and it will take the 1492 law of the Catholic Majesties as a point of arrival and departure; arrival point for the Middle Ages and departure point for the Modern times. But this article is not limited to the description, but to contextualize the various medieval laws and also to seek conclusions relating to their strengths and their lacks. Both would be kept from the Medievo to the end of the Old Regime, despite the wishes of kings, legislators and judges.
\end{abstract}

* Fecha de recepción del artículo: 23-01-2009. Fecha de aceptación del artículo: 09-02-2009.

** Universidad de Granada. Depto. de Derecho Internacional Privado e Historia del Derecho, Facultad de Derecho. Plaza de la Universidad, 1, 18071 Granada. C.e.: Idiazdelaguardia@ugr.es. 


\begin{abstract}
PALABRAS CLAVE
Derecho medieval, pleito de hidalguía, hidalgos, pecheros, Audiencias y Chancillerías, Corona de Castilla, nobleza legal (jurídica).

KEY WORDS

Medieval Law, lawsuit of nobility, nobleman, commoners, Royal Courts and Chancelleries, Crown of Castile, legal nobility.
\end{abstract}

\title{
1. RECONOCIMIENTO JURISDICCIONAL DE LA NOBLEZA EN LA CORONA DE CASTILLA: LOS LLAMADOS PLEITOS DE HIDALGUÍA Y SU PROBLEMÁTICA ${ }^{1}$
}

Una dificultad, destacada, que tuvo que afrontar la nobleza castellana en el tránsito de la Edad Media a la Edad Moderna fue la aparición de unos procedimientos jurisdiccionales consolidados, de titularidad regia, que estaban encaminados a delimitar quién en Derecho era realmente noble o no. Procedimientos diversos pero entre los que sobresalen, para Castilla, los denominados pleitos plenos de hidalguía y que poseen como punto definitivo de inflexión la labor de los Reyes Católicos. Labor que recoge un pasado bajomedieval y que lo prepara y dispone para la Edad Moderna.

De semejante temática versan estas páginas: de la evolución jurídica de lo que se vendría a denominar pleito de hidalguía, estricta y jurídicamente. Denominación que por cierto, más ahora que antes, se extiende sin precisión a cualquier actuación jurisdiccional, contenciosa o no, en la que hubo que demostrar hidalguía: por ejemplo en un concurso de acreedores donde alguien exhibiese su nobleza, a través de probanza, para servirse de ella en la causa principal; en las informaciones para recibir Estado en una localidad, sin oposición de por medio: o, por terminar con ejemplos y sin ser absoluto, en aquellos verdaderos litigios en donde lo que se discute de fondo no es la nobleza, sino el derecho a ocupar un cargo o no, etc. Pero es que estos casos y otros similares, no son verdaderos pleitos plenos de hidalguía, cuando menos en la Baja Edad Media y en la Edad Moderna, bajo el lus Commune?2.

No obstante, antes de proseguir y de comenzar este análisis se debe resaltar una característica del presente estudio; su naturaleza teleológica, casi presentista desde un punto de vista normativo. Y esto no es fruto del capricho sino de diversas consideraciones que resultan esenciales, todavía, ante la falta de un detenido estudio jurídico sobre este tipo procesal en toda su amplitud. Presentismo relativo,

1 Quiero expresar mi agradecimiento a todo el personal del Archivo de la Real Chancillería de Granada, dirigido con sobresaliente eficacia por don David Torres Ibáñez, y dedicar expresamente este artículo a doña Eva Martín López, Asesora Técnica de Gestión Documental de dicho Archivo.

2 Precisamente con esta finalidad de precisar se utiliza el término «pleno» que si bien es propio del Sistema de la Recepción del Derecho Común, es un adjetivo que se suele emplear para estos pleitos más tardíamente — siglo XVII y sobre todo XVIII - por algunos juristas para diferenciarlo de otras actuaciones llevadas a cabo por las Chancillerías y que no eran verdaderos contenciosos cuyo fondo fuera en exclusiva la determinación de la nobleza. 
pues se remonta éste a la fecha de la Recopilación de las Leyes de estos Reinos, a la llamada Nueva Recopilación, es decir a 1567, reinando el gran Felipe II.

1. La Nueva Recopilación ofrece información sobre la legislación de la Baja Edad Media que, bajo la preocupación de ajustar este contencioso al dominio regio, poseyó ya en su momento la mayor relevancia. Relevancia que aumenta al ser recopilada en la Modernidad fundamentando en ella este proceso significativamente, pero no en exclusiva, pues hubo leyes y normas posteriores, propias sólo de la Edad Moderna, que también son dignas de estudio por su importancia, aunque no sea éste el lugar.

2. Naturaleza teleológica, a veces, con reservas, permitida al historiador, pero en esta ocasión no del todo artificial y menos desnaturalizadora, pues la legislación aquí analizada revela una continuidad encaminada a someter este pleito a la Corona en detrimento de otros poderes. Aspecto que asume y explicita fundamentalmente la ley cordobesa de los Reyes Católicos de 1492, en la que sin derogar leyes anteriores, sino más bien precisándolas, confluyen en buena medida la mens legislatoris de muchos de sus regios antecesores y de los juristas y políticos servidores de ellos.

3. Falta relevante -ya mencionada - de una investigación que aúne la documentación legislativa y jurisdiccional tanto medieval como moderna, aunque sobre todo medieval, que facilite, más allá de simples y concretas ejecutorias, una visión global de fuentes de conocimiento que aseguren un claro y completo desarrollo legislativo, jurisdiccional y práctico, de lo que llegaría a ser el pleito de hidalguía.

De ahí, desde ese carácter teleológico, que el soporte documental presentado en esta investigación no desprecie, sino todo lo contrario, documentación cronológicamente posterior al momento originario de promulgación de muchas de las normas estudiadas, situándonos incluso en el siglo XVII, pero sobre todo en el XV y XVI, pues comparando normas, documentación medieval y moderna se podrá apreciar desde la realidad y la cotidianeidad el verdadero calado de la labor de los Trastámara en la creación del pleito pleno de hidalguía.

Aspecto que no debe sorprender porque tanto desde la dogmática como desde la praxis el Sistema de la Recepción del Derecho Común mantiene cierta unidad en sus conceptos y actuaciones, en tal grado que produce - se afirma esto con mucha precaución - una uniformidad jurídica y real, en el tiempo en que estuvo vigente en España.

Es hora de iniciar el estudio, pero en la Historia siempre hay un antes y en este caso, estos precedentes se encuentran en la Alta Edad Media ${ }^{3}$.

${ }^{3}$ Sin menoscabo de lo mucho estudiado y de los grandes autores que han tratado y tratan la hidalguía y los hidalgos medievales y también modernos, quizá la no realización por parte de don Claudio 


\title{
2. RES DE QUA AGITUR: EL FONDO DEL PLEITO
}

\author{
¿Qué es lo que se dirime en un pleito de hidalguía de todas las épocas? \\ Pues, como en otros pleitos de naturaleza u origen civil se dirime la titularidad de \\ un derecho, ya sea la posesión o la propiedad sobre una determinada cosa —pu-
}

Sánchez-Albornoz de la, es presumible, muy completa investigación que prometía hacer sobre estos individuos y condición hubiese dado un marco institucional idóneo para establecer rutas posteriores más seguras en este campo: «Hace muchos años que tengo reunida una variada y numerosa colección de textos que crece cada día para escribir una monografía sobre los hidalgos. Si Dios me da vida y salud no tardaré en publicarla. Véanse entre tanto...", SÁNCHEZ-ALBORNOZ, C.: «¿De los Banu Al-Jamas a los Fijosdalgo?», en Estudios Polémicos. Prólogo de Luis García de Valdeavellano. Madrid, Espasa-Calpe, 1979, pág. 232, n. 15. Con esto ni mucho menos se quiere minusvalorar todo lo que vino tras el trabajo no realizado de Sánchez-Albornoz, más bien lo contrario, que Albornoz pudiera haber fijado fronteras institucionales que faltan: sí. Pero es rotundamente obvio que existen grandes trabajos y aportaciones historiográficas sobre la nobleza o noblezas españolas acompañadas a nombres de grandes historiadores como Moxó, Suárez Fernández, etc., y en la actualidad cabe destacar por ejemplo la labor de cuatro hispanistas como J. Perez, Gerbet, Fayard o Rucqoui y sus seguidores - de esta última autora me parece realmente acertado e interesante su trabajo "Ser noble en España (Siglos XIV-XVI», en Rex, Sapientia, Nobilitas. Estudios sobre la Península Ibérica medieval. Granada, Universidad de Granada, 2006, págs. 211-248, publicado por primera vez en Gotinga en 1997. Sin olvidar a los españoles José Luis Martín, Ladero Quesada, Sánchez Saus, Pérez de Tudela, Quintanilla Raso, etc. No obstante estos autores salvo las hispanistas, sobre las que volveré, pocos han entrado en el pleito de hidalguía medieval en profundidad, con la excepción de un sector, quizá minusvalorado por algunos demasiado superficialmente, como es el de genealogistas y nobiliaristas, y no es justo. Cierto que hay de todo, pero obras como las de Cadenas y Vicent, Borrajeiros, Barredo de Valenzuela, De la Floresta, Lira Montt para Hispanoamérica etc., publicadas fundamentalmente en la revista de la Asociación de Hidalgos, la conocida revista $\mathrm{Hi}$ dalguía, y en otras instituciones como el Colegio Heráldico o la Academia Matritense de Genealogía, son obras que merecen atención y en muchas ocasiones se han acercado o tratado sobresaliente y directamente asuntos también estudiados aquí. Igualmente merece atención como visión de conjunto y para la temática de este artículo, la obra de los genealogistas, vinculados al Colegio Heráldico, Valero de Bernabé y Márquez de la Plata titulada Nobiliaria española: origen, evolución, instituciones y probanzas. Madrid, Prensa y Ediciones Iberoamericanas, 1991, sin tampoco olvidar la relativamente reciente labor de la Universidad Nacional de Educación a Distancia (UNED) y su master en Derecho Nobilliario y Premial, Heráldica y Genealogía. Ahora bien el presente artículo es escueto en bibliografía, no así en documentación ni en legislación -aunque ésta se fundamente en la más esencial-y las razones son varias, pero se resumen en una. Cierto que por ejemplo algunos de los hispanistas arriba citados se han acercado al pleito de hidalguía para la Edad Media, más como fuente que como objeto de estudio en sí mismo, pero existen excepciones o contenidas en obras de mayor calado o en otras más concretas. Y entre ellos, entre estos hispanistas se debe resaltar a las historiadoras Marie-Claude Gerbet y Janine Fayard, que tanto por separado -Gerbet en su La noblesse dans le royaume de Castille. Etude sur ses structures sociales en Estrémadure. 1554-1516, París, La Sorbona, 1979 - o conjuntamente ambas - verbi gratia «Fermeture de la noblesse et pureté de sang dans les concejos de Castille au XVème siècle: à travers les procès d'hidalguía», en SÁEZ, E., SEGURA GRAíÑO, C. y CANTERA MONTENEGRO, M. (Coords.): La ciudad hispánica durante los siglos XIII al XVI. Madrid, Universidad Complutense, 1985, págs. 443-473- han tratado los pleitos de hidalguía y los han intentado analizar. Pero trabajos que a la hora de estudiar el pleito de hidalguía - como le ocurre a modernistas como Domínguez Ortiz- se limitan por lo general a describir sin prestar atención al Derecho y olvidando que el Derecho es un elemento cultural y social determinante y cotidiano, hoy y ayer, y más aquí, en este tema - es que son pleitos y no otra cosa-, por lo que a mi juicio se les escapan aspectos que desvirtúan en gran medida sus conclusiones. Es pues este artículo, no algo acomodaticio, pero que en ningún modo pretende la confrontación y por tanto no se entrará en comparaciones ni en negaciones, pues su objetivo es muy otro: facilitar una visión nueva sobre el pleito de hidalguía que partiendo de la norma se acerque a la realidad, a través de la documentación. Y como visión, una visión particular, una aportación más al estudio de este proceso, distinta, y que sólo pretende aportar nuevas ópticas al discurso. De ahí ni la cita para redundar ni la cita bibliográfica para negar: mi pensamiento y conclusiones, con toda humildad, está expuesto en estas páginas para quien le pueda servir, aunque sea para discrepar. Y es que para todos, queda mucho por cortar. 
diendo ser ésta corporal o incorporal-y el goce de ese mismo derecho y de las facultades y deberes que lo constituyen, bajo el amparo y consentimiento del Poder político y de su Ordenamiento Jurídico.

Por tanto no corresponde al proceso de hidalguía ni a los órganos jurisdiccionales crear un derecho ex novo, porque semejante actuación, en este caso, sólo estaría atribuida a la potestad soberana que goza la Monarquía que no sólo puede crear nobles e hidalgos, sino que también puede convertir a nobles en pecheros, ya sea individualmente o pese a discusiones, incluso en grupo ${ }^{4}$.

Por lo que atañe a los pleitos de hidalguía sólo se tiene en cuenta aquella nobleza que ha transcendido del ámbito de las virtudes, de tal manera que se ha convertido en una institución amparada y reglada por el Derecho y que por tanto tiene consecuencias jurídicas, no sólo morales o sociales.

El pleito de hidalguía no viene a dirimir si una persona es virtuosa o no -teóricamente se le supone si es hidalgo - sino si es jurídicamente hidalgo o no y si puede gozar de esa condición, erga omnes, ya sea en propiedad o en posesión, no más. En conclusión, se está hablando de lo que se vino a denominar como nobleza civil o nobleza política, es decir, aquella que como institución formaba parte de la estructura jurídica y que como tal tenía la relevancia suficiente para que el Ordenamiento le prestara atención, no sólo en cuanto a su guarda, sino también en cuanto a su ejercicio. En ningún caso se pueden confundir - como a menudo hace la historiografía - el contenido de las probanzas - que a veces hablan exageradamente de virtudes- con el pleito y menos aún con la sentencia del mismo, siempre escueta por lo general, y en la que se aprecia in fine qué es lo que se discute: la nobleza política o civil - jurídica-y su titularidad.

Hay que precisar el camino que tuvo este tipo procesal y que tiene sus orígenes no dentro del Sistema Jurídico de la Recepción, sino al menos en la etapa del florecimiento del localismo jurídico peninsular. Pues es lógico pensar —no sólo lógico sino que hay rotundas evidencias- que en cualquier sociedad con un mínimo de desarrollo político-jurídico en donde entre sus individuos existen diferencias amparadas por el sistema y sus leyes, estas diferencias, del tipo que sean, no sólo están regladas por leyes, escritas o no, sino que igualmente por esas mismas leyes se establece cómo y quién debe sufrir o gozar de esas diferencias. Y eso ocurre evidentemente también con el grupo social más privilegiado y cercano al poder, llámese nobleza o en otra forma ${ }^{5}$.

4 Esa potestad regia, esa regalía, es relativa en la práctica e históricamente. Incluso según Derecho, posiblemente, sólo sería admisible para la Baja Edad Media y ya con claridad para la Edad Moderna. Sobre la problemática de las fuentes de la nobleza política o civil, de la nobleza jurídica, que ha sido abordada de diferente forma por muchos, me remito a mi artículo DÍAZ DE LA GUARDIA Y LÓPEZ, L.: «EI poder feudal como origen de hidalguía en la Baja Edad Media castellana: un ejemplo del señorío de ViIlena», Espacio, Tiempo y Forma (ETF), Serie III, Historia Medieval, 18 (2005), págs. 129-168.

5 Normativa que ampara a los privilegiados, y deseo eterno de los que no lo son de convertirse en tales, dice el Fuero Juzgo 7, 5, 6: «Quien se pone falso nombre o falso linaie, o falsos parientes, o alguna apostura falsa, sea penado como falso". 
Sin embargo conviene aquí traer a colación que durante el período de dispersión normativa y más concretamente en la Alta Edad Media previa a la Recepción, en los reinos que compondrían la Corona castellana la actividad encaminada a demostrar, en caso de contradicción, la calidad de hidalgo debió estar preferentemente incluida en el ámbito privado - por lo que respecta a la generalidad de los casos-o en los niveles del Derecho local ${ }^{6}$.

Siendo cierto que en esta etapa previa a la Recepción e inclusive durante buena parte de ella, una vez reinando el Derecho Común en Castilla, la forma más usual y eficaz de dirimir la pertenencia o no de un individuo al Estado de los $\mathrm{Hi}$ josdalgo era aquella que se realizaba por vías privadas o cercanas a la actividad privada, no es menos cierto que esto no impidió que existieran fórmulas que, superando el arreglo particular de controversias o la simple participación de jueces-ár-

6 El cariz jurídico-privado medieval de la condición nobiliaria no sólo se resume al ámbito de la demostración de la misma hidalguía, sino también a la autonomía de la voluntad de su titular en el ejercicio de su condición y facultades. Autonomía que no sólo afecta a ese titular, sino por igual a terceros, ya sean mujer y descendientes, como a los que le rodean, como a la sociedad en la que está inserto. Si nos atenemos a la doctrina que viene a considerar el Fuero Viejo y otros textos similares, como recopilación de costumbres, fazañas y normas nacidas previamente en el tiempo a su recopilación, en ocasiones destacadamente, podemos utilizar a éste como soporte de lo dicho tanto para la Baja como para parte, también pero precavidamente, de la Alta Edad Media —resultaría interesante recopilar y publicar, para un estudio profundo de la nobleza medieval castellana, los textos similares al citado Fuero, un ejemplo relativamente reciente lo tenemos en BERMEJO CABRERO, J.L.: «Un texto afín al Fuero Viejo de Castilla: «El Fuero de los fijosdalgos y las Fazañas del Fuero de Castilla», Anuario de Historia del Derecho Español, 69 (1999), págs. 239-274. Los ejemplos de esta autonomía de la voluntad —no todosson puntualmente conocidos, están por ejemplo en el famoso Fuero Viejo (FV), pero del mismo modo han sido meticulosamente y mayoritariamente obviados de cualquier análisis, por los que se dedican a estas lides, salvo raras excepciones, los preceptos más evidentes y contradictorios contra el discurso monolítico nobiliario posterior y más aún historiográfico. Si, según nuestros historiadores, toda persona que podía, irresistiblemente, estaba abocada a renunciar a su origen por ser noble — cual ley matemática, ¿cómo el citado Fuero recoge un acto jurídico y prototípico, para renunciar a la calidad nobiliaria voluntariamente? FV 1, 5, 16 y nota 2, pág. 24 de la edición del Fuero Viejo de Jordán de Asso y De Manuel, Madrid, 1847, Imprenta de la Viuda e hijos de D. Antonio Calleja, en la que se referencia, en la nota, a modo de ejemplo, un similar acto jurídico al prescrito por el Fuero. Lo que, por otra parte, incide y evidencia en que esto no era algo escaso, ni debía ser raro o singular. Mejor o desconocerlo o no explicarlo, $\mathrm{y}$, si se hace, apuntar o insinuar la dudosa condición hidalga del renunciante, las más de las veces sin apoyatura ninguna o consistente, y desde luego no jurídica. Más allá, si en nuestro subconsciente y consciente historiográfico y común el que nace de nobles suele morir noble, salvo terrible y concreto delito, ¿cómo explicar que ese mismo precepto establece que mientras que el hidalgo renunciante sea tenido y se tenga por pechero, todos los que nazcan de él -incluso cumplidas cualesquier exigencias de legitimidad, etc. en su nacimiento- serán legalmente pecheros y sus descendientes también, sin, en principio, posibilidad de retorno a gozar de un derecho del que nunca fueron titulares ni acreedores? La explicación jurídica es meridiana y no conflictiva. Para la historiografía no tanto, mejor o despreciar el tema y su naturaleza jurídica o volver a la duda nobiliaria de la persona: es lo más cómodo. Norma que, por cierto, está directamente enlazada con otras de la Edad Moderna, también silenciadas y mucho más incómodas para el discurso historiográfico, casi inexplicable desde él: me refiero por ejemplo, y entre otras a las que haré referencia en adelante, como a la que prohibe el libre uso y renuncia, que hasta entonces se había dado, de ciertas facultades propias de hidalgos, por parte de ellos mismos, Nueva Recopilación (NR), 6, 3, 14. Volviendo al Fuero Viejo por ejemplificar esa autonomía de la voluntad del hidalgo medieval, no con carácter absoluto ni mucho menos, pero sí en un punto importante como es la capacidad por parte del titular de la hidalguía de disponer arbitrariamente de ella para con sus hijos naturales, basta lo normado a continuación: «Esto es Fuero de Castiella: Que si un fijosdalgo a fijos de barragana, puedelos facer fijosdalgo, e darles quinientos sueldos...», FV 5, 6, 1. 
bitro, vinieran a someter la pendencia a la resolución de juez, real o señorial, pero en último caso a la decisión de una persona que posee naturaleza jurisdiccional sin discusión. El mismo Fuero Viejo evidencia lo dicho:

Esto es Fuero de Castiella: Que si algund ome contradijier que no es Fijodalgo, e aquél a quien contradice, dijier que lo es, dévese facer Fijodalgo con cinco testigos, los tres Fijosdalgo e los dos labradores, o con dos Fijosdalgo e tres labradores, sin jura. E este dicho que ellos dirán, dévelo oir el Fiel, que es dado de amas las partes, estando amas las partes delante; E este Fiel debe tornar los dichos de los testigos al Alcalle, que judga el pleito, e para esto an nueve días de plaço ${ }^{7}$.

Por tanto existencia de diversos modos - particular y jurisdiccional- para alcanzar un mismo objetivo, el reconocimiento de la condición de un individuo como hidalgo y de gozar libremente, pero conforme a Derecho, de las facultades que adornan a esta calidad.

La misma ley del Fuero Viejo invita a interrogarse por quién poseía la competencia - dentro del ámbito jurisdiccional- para conocer de este tipo de controversias cuando buscaban la protección de un juez.

La figura del alcalde de los Hijosdalgo medieval ciertamente necesita de mayores estudios de los hasta ahora existentes para saber si a él le pertenecía el conocimiento de este tipo de causas desde el inicio de su creación, pero lo que sí es cierto es que si la tuviere y la tuvo con los siglos, esta competencia no la poseía por entonces en exclusiva. Dependiendo de zonas y de tipologías jurisdiccionales a nivel local o territorial el órgano competente que se ocupaba de los pleitos de hidalguía variará, aunque sí hay, parece, una evidencia, y es que desde luego no se trataba de casos de Corte como se conformarán los pleitos de hidalguía desde fines del Medievo castellano y después en la Modernidad.

En realidad el proceso de hidalguía podía ser competencia de cualquier juez, señorial o real, o incluso de la asamblea de vecinos. Estas jurisdicciones podían conocer de los pleitos de hidalguía y no se necesitaban de apelaciones ex lege a ninguna instancia superior para que la sentencia no sólo recayera firme y estuviese perfeccionada en sus efectos conforme a Derecho, sino para que una sola sentencia y de un juez, se puede decir, de escaso rango pudiera perfectamente amparar a una persona según Derecho en su nobleza o establecer que no lo era y que debía ser pechera y nombrada por tal ${ }^{8}$.

7 FV 1, 5, 18.

8 Los ejemplos son muchos en los que alcaldes foreros, alcaldes ordinarios, corregidores, etc., lo protagonizaron, y también son muchos los conservados, más, es lógico, los cronológicamente relativos a la Baja Edad Media que a la Alta, y aunque se volverá sobre esto, sirva de muestra lo siguiente: el corregidor de Medellín, bachiller Ramón, se reconocía como juez natural de los pleitos de hidalguía de su jurisdicción. Lo hacía reiteradamente y así amparó, en juicio, la hidalguía de Pero Martínez Zambrano a fines de la Edad Media, en contra de las pretensiones del concejo de Guareña donde el hidalgo era vecino. No obstante en esta ocasión no quedó libre el hidalgo y la potestad del juez indiscutida. El concejo acudió al Consejo y éste dio real provisión en Toledo, el 30 de abril de 1498, emplazando por un lado al hidalgo a contender ante los jueces competentes - los alcaldes de los Hijosdalgo de Ciudad 
El Fuero Viejo viene a significar que, todavía cercano el ejercicio privado de la condición de noble, una simple diferencia entre particulares podía ser motivo para acudir ante la jurisdicción en busca de dirimir estados.

Frente a los orígenes difusos del pleito de hidalguía, la Baja Edad Media supone un impulso cuantitativo pero sobre todo cualitativo en su evolución, cambio evolutivo sustancial que está prístinamente relacionado con la casa de Trastámara y con el Sistema Jurídico de la Recepción del Derecho Común y su utilización para fundamentar el poder regio.

Pero el pleito de hidalguía conformado durante el Sistema de la Recepción no surgirá ex nihil, sino que -negando, matizando o asimilando- se configurará en torno a cuatro elementos derivados del altomedievo:

1. La cuestión de fondo del pleito de hidalguía únicamente versa sobre la titularidad de lo que vendría a denominarse nobleza política o civil: la nobleza entendida como institución jurídica.

2. La causa metajurídica que dará lugar al litigio no se encuentra delimitada. Siendo de tal modo amplia, que la simple negación verbal de la calidad de hidalgo puede considerarse digna de amparo jurisdiccional.

3. La competencia jurisdiccional objetiva no está atribuida exclusivamente a ningún tribunal, tampoco la subjetiva u otra, ni siquiera a los alcaldes de los Hijosdalgo, por lo que lejos de poseer la naturaleza de caso de Corte podrá conocer de este contencioso cualquier jurisdicción civil, quizá incluso hasta la criminal.

4. Junto a la indeterminación jurisdiccional que soporta este contencioso, es posible que por ello, conviven con éxito las actuaciones privadas o cercanas a ellas para reconocer la nobleza y el goce de la misma.

\footnotetext{
Real-y, por otro lado, apercibiendo al corregidor de que no volviese a entender de pleitos plenos de hidalguía, Archivo General de Simancas (AGS), Registro del Sello, 1498 abril, fol. 234. Esta vez se apeló, la legislación protegía más efectivamente a Guareña, pero con anterioridad y pese a existir alguna norma, no solía acontecer semejante resultado y el hidalgo quedaba dado por tal y por caso no por un corregidor sino por un simple alcalde ordinario, como ocurre en Sevilla por sentencia del alcalde ordinario Gonzalo González de León, dada el 27 de octubre de 1406 a favor de Pedro García de Ahumada, dándolo por hidalgo y eximiéndolo del pago de la Moneda Forera, Archivo de la Real Chancillería de Granada (ARChG), Pergaminos, n. ${ }^{\circ} 107$, o igualmente en la ciudad hispalense ahora por el alcalde mayor, por el mismo medio y con el mismo fin en favor de Alonso Díaz de Herrera a 18 de abril de 1496, ARChG, Pergaminos, n. ${ }^{\circ} 179$. También por alcalde ordinario en Murcia, en sentencia de 16 de junio de 1436, donde el alcalde Ruiz de Sandoval dio por hidalgo a Alfonso Yáñez de la Ballesta, la trascripción completa de la sentencia en DÍAZ DE LA GUARDIA Y LÓPEZ, L.: «El deber de fidelidad al rey como justificación de hidalguía en la nobleza de España e Indias», Anuario Mexicano de Historia del Derecho, XV (2003), págs.139-140.
} 


\section{LOS PLEITOS DE HIDALGUÍA EN LA BAJA EDAD MEDIA}

Con escaso éxito en la práctica, entendida a corto plazo dentro de los siglos de la Historia castellana, y con éxito a largo plazo, es conocida la utilización del Derecho Común por parte de los soberanos para ir justificando un poder lo más absoluto y lo más omnímodo posible. El ejemplo alfonsino y sus Partidas, sin olvidar otros textos, es patente ${ }^{9}$.

Y pese a que la dinastía Trastámara sufrió las convulsiones de su tiempo y las debilidades de algunos de sus reyes y la prodigalidad de muchos de ellos en virtud de su misma carencia de fortaleza, no es menos cierto que por medio de las leyes que van estableciendo, los mencionados Trastámara procuran con ellas ir cimentando el poder de su dinastía y la potestad real absoluta, e independientemente de que en esos turbulentos reinados se llegaran a conseguir las metas propuestas, resulta obvio que se establecieron antecedentes, aquí, legislativos que fueron utilizados por sus sucesores - como los Reyes Católicos-con eficacia.

Por lo que respecta a los pleitos de hidalguía ya aparece al inicio de la nueva dinastía un precedente normativo importante, más por sus consecuencias con los años y por lo que se refiere a plantas jurisdiccionales, y surge concretamente con el instaurador de los Trastámara, al dictar Enrique II una ley por la que se obligaba a que en su Audiencia existiesen dos alcaldes de los Hijosdalgo ${ }^{10}$.

9 Parece ser que a él, a Alfonso X el Sabio, se debe la existencia de la figura institucional del alcalde de los Hijosdalgo, creando dos en 1271. No obstante, vista la legislación antecedente y las mismas peticiones contemporáneas del reinado alfonsino, dudo que existiesen con anterioridad jueces especiales y permanentes, que entendiesen en exclusiva y preferentemente sobre quién era y quién no hijodalgo dentro del reino castellano-leonés. Y, desde luego, ni la legislación ni la documentación, avalan la existencia previa a Alfonso $X$ de éstos ni menos que, incluso, normado por el rey Sabio se acatase en todo el reino semejante cuestión y que entendiesen sobre pleitos en los que se dirimía la condición jurídica de noble como se afirma generalmente, Vid. por ejemplo VARONA GARCÍA, M. ${ }^{a}$ A: La Chancillería de Valladolid en el reinado de los Reyes Católicos. Valladolid, Universidad de Valladolid, 1981, pág. 142-143. A mi juicio estos alcaldes de Hijosdalgo primitivos debieron ocuparse estrictamente de pleitos entre nobles y de estos con el rey. Y no - usualmente- entre nobles y otras universidades, concejos, repartidores o simples pecheros, y menos cuando por estos últimos les era contradicha su calidad. La documentación demuestra más bien lo contrario en estos tiempos y mucho después. Ya se ha ejemplificado, Vid. nota ut supra. Pero esa tendencia a solicitar una jurisdicción propia para sus asuntos y la existencia de una repulsa a que sus no iguales entiendan de sus actividades, está presente, no al rango de la situación alfonsina claro está, entre los nobles españoles hasta inicios de la Edad Moderna, como poco. Y sirvió a los hidalgos, en muchas ocasiones, desde el siglo XIII, pero sobre todo desde el XIV y XV, para conseguir oficiales de mayor o menor rango dentro de los municipios pecheros, fuera para casos concretos o permanentes, y, más tarde, para obtener la mitad de oficios: dicen los hidalgos de Alcázar de San Juan sobre un repartimiento «que era contra Derecho (el repartimiento) e contra todas las costunbres de todas las çibdades, villas y lugares de estos mis reynos donde avía hidalgos, que entre ellos se fazían sus repartimientos sin entender los pecheros en los casos en que eran obligados y ponían su cogedor, porque cosa rezia y e contra razón era el pechero repartir sobre el hidalgo porque él le repartiriría lo que quisiese sobre otras personas que eran de su suerte e condiçión», ARChG, Hidalguía, Caja 5074, pz. 59. Algunos ejemplos más de esto en DÍAZ DE LA GUARDIA Y LÓPEZ, L.: «La mitad de oficios en concejos. Madridejos y otros casos entre el Medievo y la Edad Moderna», en ETF, Serie III, Historia Medieval, 20 (2007), págs. 43-95.

10 NR 2, 11, 1. Sobre las salas de los Hijosdalgo chancillerescas es clásico ya el trabajo siguiente, MARTÍN POSTIGO, M. ${ }^{a}$ S.: La Sala de los Hijosdalgo de la Real Chancillería de Valladolid. Valladolid, 
Sin restar significación a la disposición de Enrique II, inclusive la política, otras normas de sus sucesores marcaron una impronta mayor en el contenido procesal de la demostración jurisdiccional de la nobleza.

\section{a) Juan I: el pleito de hidalguía como caso de Corte. ¿Defensa o someti- miento de la nobleza?}

Dentro de la evolución bajomedieval de la nobleza castellana y en el ámbito de las fricciones entre ésta y la Corona para determinar en dónde reside el poder efectivo y verdadero del Reino, se debe incardinar la aparición de una ley, que terminó siendo recopilada, y que venía a romper normativamente con prácticas y ejercicios en cuanto a pleitos de hidalguía se refiere. Se trata de la pragmática dada por el rey Juan I en 1379 (Era, 1417) en virtud de la petición XIX de las Cortes de Burgos:

Ordenamos que el Fijodalgo que no fuere dado en nuestra Corte y Chancillería $\mathrm{y}$ con el procurador del lugar donde mora, y con nuestro procurador por Fijosdalgo, que la sentencia que por él fuera dada sea ninguna: $y$ si después de dada la sentencia contra nuestro procurador, el Concejo del lugar donde viviere, opusiere no ser verdadero Fijodalgo, que lo debe de poner en nuestra Audiencia: y mandamos que sea oído y le sea administrada justicia, porque nuestros derechos sean guardados $^{11}$.

Aparentemente nace, la ley arriba transcrita, para evitar atropellos en favor de los que se decían hidalgos o en contra de ellos, según y en virtud de las razones

Ámbito, 1990. Para Granada destaca también, en cuanto a monografía sobre esta Sala, GÓMEZ GONZÁLEZ, I.: «El derecho penal al servicio del Estado. La transformación en criminal de la sala de los hijosdalgo de la Chancillería de Granada", en CASTELLANO CASTELLANO; J, L., DEDIEU, J,P., y LÓ-

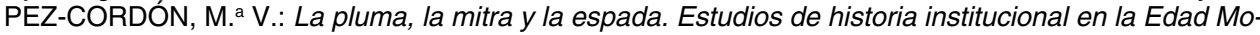
derna. Madrid, Marcial Pons, 2000, págs. 303-318. No obstante y como obra general de referencia para las Audiencias es muy útil GARRIGA ACOSTA, C.: La Audiencia y las chancillerías castellanas (13711525): historia política, régimen jurídico y práctica institucional. Madrid, Centro de Estudios Constitucionales, 1994. La bibliografía de las Audiencias tanto penínsulares como del resto de la antigua Corona de Castilla es muy amplia, con grandes nombres entre sus autores. Para Granada destacan trabajos como el de la citada profesora Inés Gómez González, GÓMEZ GONZÁLEZ, I.: Las justicia, el gobierno y sus hacedores. La Real Chancillería de Granada en el Antiguo Régimen. Granada, Editorial Comares, 2003, el más actualizado, o el de los profesores Gan Giménez o Ruiz Rodríguez, etc. Últimamente se ha editado un magnífico libro conmemorativo del quinto centenario de la Chancillería de Granada, elaborado por varios autores entre los que se encuentra el ya citado Carlos Garriga, en el que se aportan nuevas perspectivas, visiones y campos de trabajo: MOYA MORALES, J., QUESADA DORADOR, E., y TORRES IBÁÑEZ, D.: Real Chancillería de Granada. Quinto centenario, 1505-2005. Granada, Junta de Andalucía, 2006. Por último no ha de olvidarse bajo ningún concepto, una obra muy útil y clarificadora para cualquier estudioso de la justicia y del gobierno al sur del Tajo y, en fin, para toda la Corona de Castilla, como ha sido la edición del manuscrito nunca impreso de la Práctica de Granada y del que aún se desconocía el autor - ya sí aclarado por el catedrático de Historia del Derecho y de las Instituciones José Antonio López Nevot- como es el siguiente libro, LÓPEZ NEVOT, J.A.: Práctica de la Real Chancillería de Granada. Estudio preliminar y edición del manuscrito 309 de la Biblioteca Nacional de Madrid. Granada, Editorial Comares, 2005. No obstante, todas estas Cortes y Audiencias son dignas de la prosecución de su estudio, Granada en especial, durante mucho tiempo minusvalorada injustamente con respecto a Valladolid, merece nuevos trabajos tanto de conjunto como particulares.

11 NR 2, 11, 12. 
verdaderas que habían dado razón al litigio y que se encontraban tras él. Lo que indica, también, que se elevó a caso de Corte algo que hasta entonces no lo había sido y que como en los otros supuestos que alcanzaron tal categoría se hizo para resolver una problemática amplia, relevante para la sociedad, y para conseguir, o mejor, buscando conseguir que la solución de la controversia gozara de las máximas seguridades jurídicas.

Pero esta ley encerraba una intencionalidad política trascendental de mayor alcance. Con toda probabilidad fue éste el verdadero motivo de su promulgación: conceder al Monarca y a sus más cercanos y altos tribunales la competencia en exclusiva para establecer quién y quién no era hijodalgo, quién y quién no era noble. Algo realmente significativo en aquella sociedad.

Para los hombres de la Edad Moderna, para políticos y teóricos, para juristas y, cómo no, para los nobiliaristas parecen ser las facultades de la hidalguía, de la nobleza en sentido amplio, algo milenario, inmemorial, y sobre todo inmutables como la nobleza y la hidalguía misma, y que además escapan al control del poder político en cuanto a su nacimiento y conformación, quedando por tanto a éste la única vía de reconocerlas y protegerlas. Desgraciadamente esto también sirve para interpretaciones historiográficas actuales y de diferentes tendencias. Pero lo cierto es que esto no fue así12.

Y de esto último, esta misma ley es un ejemplo, y sin retrotraerse a códigos o colecciones de fazañas ni a otro tipo de documentación de nuestra Alta Edad Media, muchas de las leyes recopiladas dan constancia de ello, de su mutabilidad, e incluso las mismas Cortes de Castilla de los siglos XIV, XV y XVI.

La labor legislativa para establecer, limitar o ampliar —raramente- y determinar los derechos de los hidalgos que realizan los Trastámara es patente y que

12 La historia política de Castilla lo evidencia, pero también la jurídica. Y no sólo en ámbitos secundarios, sino también en circunstancias aparentemente muy conocidas y mayoritariamente asentidas: el régimen fiscal y las exenciones nobiliarias. Éstas fueron siempre cambiantes según zonas, personas, circunstancias, normativas locales y generales, y épocas. Y no me refiero a que por ejemplo muchas de ellas se devaluaran cuantitativa y cualitativamente con el tiempo, de lo que es emblema la exención nobiliaria en la Moneda Forera y su poca importancia económica, sobre todo en la Edad Moderna, antes de la definitiva extinción de este tributo. El conjunto de exenciones e inmunidades fiscales nobiliarias -que todavía no posee una interpretación actualizada y de conjunto, pero detenida, por parte de la historiografía - se conforma, como punto de partida, desde una mítica e idealizada realidad absoluta en la que se presenta al noble totalmente libre y que quizá tenga su verdad en la Alta Edad Media, para, parsimoniosamente, ir configurándose de forma muy distinta, pese a quejas particulares o generales de los nobles, en torno a dos pilares que buscan su debilitamiento o su inexistencia: la realidad local y sus fueros — no exentos de privilegios, pero sí contrarios a los externos a cada fuero local y, más, a los de origen nobiliario, de lo que hay constancia expresa- y la Corona, que conforme se va fortaleciendo desde la Baja Edad Media y sobre todo en la Edad Moderna con claridad, ve en las pretensiones nobiliarias de exención un lastre a su política, pese a que ella misma y sus servidores persistan en el fondo en respetar esa idea de la originaria inmunidad total y medieval de los hidalgos — que es parte del discurso clásico nobiliario de todos los tiempos. Se aprecia en siglos de necesidad acuciante, como en el XVII. Sobre esta mutabilidad de las exenciones nobiliarias y su imprecisión, restricción y particularismo y su directa relación, por lo que se refiere a su configuración, con el Derecho local bajomedieval, Vid. DÍAZ DE LA GUARDIA Y LÓPEZ, L.: «Exención fiscal nobiliaria en el ámbito local bajomedieval. En torno a tres documentos de la villa de Belmonte», ETF, Serie III, Historia Medieval, 19 (2006), págs. 137-173. 
esto, el conjunto de facultades nobiliarias y su evolución, eran una preocupación regia pero también social es visible entre otros lugares en las Cortes. La primera ley de Juan I aquí citada es muestra clara y singular al atribuirse el conocimiento de las causas de hidalguía, la potestad de reconocer la nobleza, que es quizá el culmen mismo de toda esta problemática.

Frente a la práctica privada o al posible conocimiento por cualquier instancia jurisdiccional de un contencioso en donde se plantee como cuestión de fondo la nobleza de un individuo, Juan I estructura su ley de 1379 en tres puntos esenciales:

1. Sólo se podrán ver este tipo de litigios por la Corte y Chancillería regia, excluyendo cualquier otra instancia de su conocimiento.

2. Para que el proceso se desarrolle con perfección tendrán que ser partes contrarias al que se dice hidalgo, el procurador del lugar donde morase y el procurador regio.

3. Si la sentencia fuera contraria al procurador regio y el concejo siguiera oponiéndose a la nobleza de su morador, debe apelar la sentencia sólo ante la misma corte.

El pleito de hidalguía convertido en caso de Corte y ya sí, posiblemente, en exclusiva, como jueces naturales, visto por los alcaldes de los Hijosdalgo que introdujese en la planta de la Audiencia Real y Chancillería, en su tiempo, el rey Enrique II.

No menoscabando la importancia primordial de instituir el pleito de hidalguía como caso de Corte, es necesario destacar que Juan I con su ley de 1379 añade una vertiente pública decisiva al proceso al incorporar necesariamente la intervención, no sólo del procurador del lugar de residencia del presunto hidalgo, sino, lo que es más importante, la del procurador - se entiende con funciones fiscalesdel rey. Sin olvidar, por último y en el mismo sentido, que no simplificaba en modo alguno el litigio a favor del hidalgo, pues admitía ex lege la apelación de la sentencia por el concejo, reforzando la precariedad de sola una decisión sobre el fondo para que recayera la calidad de cosa juzgada en la nobleza del hidalgo.

Así Juan I aleja definitivamente con este modelo procesal la naturaleza privada del pleito de hidalguía y modifica su idiosincrasia civil acercándolo a lo que la doctrina del Derecho Común llamaría pleitos mixtos, dado que la presencia obligatoria del procurador fiscal regio denota la importancia que para la Monarquía había alcanzado el reconocimiento o no de la hidalguía de una persona, importancia a la postre residente en la vertiente fiscal que conllevaba la condición hidalga. Y es que sin olvidar la trascendencia meramente política — la Monarquía único árbitro jurídico para decidir sobre la nobleza de las personas-, la Corona sufría económicamente el gran número de inmunidades tributarias y no sólo tributarias, surgidas de multitud de Derechos, fundamentalmente del Derecho local, eclesiástico y no- 
biliario. Sufrimiento padecido por la Monarquía tanto como señor feudal en algunos de sus territorios, y ya en un estadío superior, actuando como poder absoluto en ciernes. De ahí el interés inmediato del Soberano para someter a su control el pleito de hidalguía, pues en principio por medio de la actuación del fiscal no sólo evitaría que sujetos no nobles terminaran hidalgos sino que incluso conseguiría que fincaran pecheros aquellos que por cualquier circunstancia no pudiesen demostrar su verdadera nobleza, alcanzando por ambos medios que el número de los posibles contribuyentes aumentara.

El rey, aquí Juan I, garante de la nobleza castellana no podía presentar su discurso legislativo y sus intereses como contrarios a los de un pilar esencial de la Corona, y para evitarlo se resguardará en el tradicional discurso monárquico que atribuye a esta institución una relación de preferente favor con los nobles. Pronto, estas leyes que en definitiva cercenaban la libertad del Estado de los Hijosdalgo como grupo social y como institución, se justificarán por ejemplo en el altruista deseo regio de garantizar la pureza de la nobleza de Castilla.

Por quanto siempre nuestra voluntad fue y es de hazer merced a los hijosdalgo de nuestros reynos, y de les guardar sus franquezas y libertades, y les mantener sus fueros, y buenos vsos y costumbres que sienpre huuieron, según que mejor y más cunplidamente les fueron guardados y mantenidos en tiempo de los reyes donde nos venimos, y del rey don Enrique, nuestro padre, que Dios perdone, y de gelos no quebrantar ni menguar: nuestra merced y voluntad es... ${ }^{13}$.

En definitiva se puede asumir conjuntamente que la legislación referente a los hidalgos y que puede ser aplicada en los procesos de hidalguía, no suele ser, pese a lo comúnmente pensado y defendido, ampliadora de los privilegios nobiliarios, sino más bien restrictiva pues los cercena aunque sólo sea al delimitarlos por ley escrita, haciendo difícil ya su evolución hacia mayores cotas de libertad y además excluyendo del goce de esos mismos privilegios, en principio, a todos aquellos que no cumpliesen el supuesto que la misma ley había establecido y que de no haberlo hecho les habría permitido, a los desde entonces excluidos, seguir gozándolos o intentándolo.

Sólo con esta ley, el monarca Trastámara, se convirtió en el gran impulsor del sometimiento del pleito de hidalguía al control regio y también en su inicial constructor para la modernidad. Pero es que incidiendo en la significación de Juan I para el proceso de hidalguía, no será aquélla la única disposición del monarca en esta materia sino que existirá otro no menos relevante, ley cuyo inicio ya ha servido aquí para ejemplificar la propaganda de la Monarquía como valedora de los derechos inmanentes a la nobleza (NR 2,11,7) y ley que en realidad restringía las libertades y posibilidades de un individuo hidalgo en salvaguardar sus derechos por lo que respecta al fisco.

13 NR 2, 11, 7. 
Esta ley de Juan I, datada en 1384, venía a declarar qué hidalgos no debían pechar bajo ningún concepto a los concejos -lo que implica por otro lado el asentamiento progresivo de este tipo de sujeto en las localidades, entendido como individualidad y en consecuencia separado hasta cierto punto de las relaciones feudales castellanas, y la lógica problemática resultante ${ }^{14}$.

Los concejos en virtud de su costumbre y en ocasiones de sus nuevas intenciones, de que todos los vecinos habían de pechar, los empadronaban: los nuevos, ya sí, vecinos o a veces tan sólo «moradores», pero nobles, se negaban en virtud de sus pretendidas inmunidades personales. Había una confrontación de derechos que empieza a dar lugar a prendas, ejecuciones y litigios. Era necesario que el Soberano interviniese precisando quién estaba exento y debía hacerlo por ley general. Así lo cumple Juan I que viene a decir:

todos los hijosdalgo, que son hijosdalgo de padre y abuelo, que estuvieron en posesión de hidalguía de tanto tiempo acá que memoria de hombres no es en contrario, y de veinte años acá, nunca pecharon ni usaron ni acostumbraron pechar ni pagar monedas, ni en pechos que acostumbran pagar los buenos hombres pecheros, ni en alguno de ellos, por ser ellos y cada uno de ellos hijosdalgo, salvo si no fuese por fuerça o premia que los dichos concejos les huviesen hecho, que no paguen ni pechen ellos, agora, ni de aquí adelante, y que les sean mantenidas y guardadas las franquezas y libertades que siempre huvieron los hombres hijosdalgo ${ }^{15}$.

Juan I en 1384 para proteger a la nobleza del avasallamiento de su inmunidad fiscal por parte de recaudadores y concejos, había dispuesto esencialmente las siguientes medidas:

1. Sólo el hidalgo cuyo padre y abuelo también fueron hidalgos y su nobleza sea inmemorial, podrá venir a ser acreedor a la exención, con lo que dejan

14 Sobre este asunto me remito a mi tesis doctoral Litigios de poder en concejos de la Real ChanciIlería de Granada: pecheros e hidalgos. La mitad de oficios en los siglos XV y XVI, (Tesis doctoral s.p.), UNED, 2003. En la actualidad estoy preparando una obra sobre esta temática para la Corona de Castilla, de forma más amplia, que pronto verá su publicación.

15 NR 2, 11, 7. La ley sigue diciendo «y mandamos a todos los Concejos, alcaldes y iurados y justicias y alguaziles de qualesquier ciudades, villas y lugares de los nuestros reynos y a los empadronadores y cogedores de monedas y pechos y servicios y a cada uno de ellos todo lo que sobredicho es. $Y$ no los empadronen ni consientan empadronar por los dichos pechos, ni alguno de ellos, agora ni de aquí adelante, salvo en el servicio de las doblas y en las otras cosas que pagan los hombres hijosdalgo. Y que les guarden sus franquezas y libertades que los hijosdalgo han y les acostumbraron a guardar por siempre y de los dichos veinte años acá y les no vayan ni pasen contra ellas en manera alguna, no embargante que ellos o alguno de ellos nos sirvieron en el abono y servicio de los quinze quentos y medio que los dichos nuestros reynos nos dieron este año que agora pasó de mil y trescientos y ochenta y ocho por fuerça y premia que sobre ello les hizieron los dichos concejos y juezes en que pagasen en ello. $Y$ si alguna cosa les tienen tomados por ello se lo tornen todo sin faltar cosa alguna y les quiten de los padrones». La Historia demostró que los concejos de Castilla no respetaron esto, pues lo pleitos de numerosas localidades entablados por los concejos o por los mismos hidalgos a raíz de que se les habían repartido o se les quería repartir todo tipo de pechos al Estado de los Hijosdalgo de ellas en conjunto, son evidencias de que pese a la ley de Juan I la situación no había sido solucionada, cuando menos de forma contundente hasta los primeros años treinta del siglo XVI, sin olvidar los casos concretos contra individuos o familias, que se mantienen hasta el fin de la Modernidad. 
de serlo salvo prueba en contrario todos los que no pudieran certificar esto, aunque fueran ellos hidalgos y tenidos por tales. Verbi gratia por falta de memoria o porque sólo pudieran demostrar la nobleza paterna o porque el padre pechó pero el abuelo no, o porque ambos pecharon, etc.

2. Serían exentos aquéllos que cumpliendo lo anterior, es decir siendo hidalgos, de sí, de su padre y abuelo y de nobleza inmemorial, además no hubiesen pechado ellos, su padre o abuelo, en tributos pecheros en veinte años antes a la ley (1384). Pero si habían pechado, sólo si lo realizaron compelidos a la fuerza por el concejo $u$ otra autoridad $-\mathrm{y}$ lo pudiesen demostrar- serían exentos, en caso contrario aunque hidalgos pecharían.

3. Cumpliendo lo contenido en los dos puntos antecedentes los hidalgos serían exentos, pero no en determinados servicios como el de las doblas o en todos aquellos pechos que se consideraban y se considerasen de obligatoria contribución para la nobleza.

Protección aparente de los hidalgos y forma de evitar pleitos pues los pueblos y demás localidades están obligados en principio, sin oponer nada, a acatar la ley y por tanto a no venir jamás a empadronar a éstos. Pero, obviando que la ley sólo se acató por los concejos en lo que les era favorable, todos aquellos - quizás descendientes del padre del glorioso e hidalgo por antonomasia, Cid Ruy Díaz de Vivar- notorios hijosdalgo que no cumplían con este requisito o no lo podían demostrar ¿qué hacían? O pechar o pleitear si podían en defensa de sus inmunidades.

El Rey, el poder soberano, había dejado excluidos de su protección a un buen número de nobles que por cualquier circunstancia se vieran alguna vez empadronados, aunque fuese excepcionalmente, o a todos aquellos que no podían demostrar, en tiempos en donde sólo la prueba testifical era la usual, que su abuelo vecino de las Montañas, por ser clásicos en el discurso, había sido hidalgo y respetado por tal, cuando en la localidad en donde ahora vivían, por ejemplo Murcia, sólo conocían a su padre y a él mismo, pues fue el padre el primero en llegar a avecindarse allí o quizá sólo una generación, el hidalgo interesado, era la primera persona de su linaje que había llegado a vivir a una nueva localidad. A muchos sin duda sólo les quedaba pleitear, si podían, si no serían pecheros y sus hijos también, olvidándose con el tiempo su inicial condición noble. Por ejemplo a inicios del siglo XVI vivían en Moclín los hermanos Diego, Pedro, Francisco, Matías, Juan y Rodrigo de Colmenares - tierra libre de pechos- pero su origen no era de esta villa granadina sino de Villanuño, Cervera y Carrión de los Condes. Su padre fue teniente de alcaide de la imponente fortaleza de Moclín, que tanta importancia tuviese en la Toma de Granada. Muerto éste, allí moraban sus hijos, pero nunca hubo documentación alguna ni necesidad jurídica de demostrar su nobleza, salvo hasta que se les repartió la Farda de la Mar por el concejo: se opusieron y fueron prendados. Más allá de la inexistencia de padrones u otros instrumentos o testi- 
monios que atestiguasen su hidalguía y el que no fuere notorio que la habían poseído y dado muestras de ella en su lugar de habitación, su gran problema residió en demostrar su filiación: su padre había sido el primero en llegar a Granada, pero hacía tiempo que había muerto y pese a haber sido personaje de rango —alcaide de la fortaleza - nadie conocía o quería recordar su ascendencia:

Pero Ximénez de Luque, vezino de la dicha villa de Moclín, ome bueno pechero que se dixo ser. So virtud del juramento que hizo dixo que hera de hedad de çinquenta e çinco años y que conosçía a los dichos Diego de Colmenares e Pedro y Françisco e Matías y Juan e Rodrigo de Colmenares, sus hermanos, de quinze años a aquella parte poco más o menos. E que el dicho Diego de Colmenares sería de hedad de veynte e quatro o veynte e çinco años y los otros sus hermanos heran niños pequeños y que todos ellos heran solteros por casar y que los avía conosçido por vista y habla e vezindad. E que asimismo conosçiera a Juan de Colmenares, su padre, vezino que fuera de la dicha villa de Moclín, ya defunto, y que avría quinze años, poco más o menos, que le començara a conosçer, que avía que viniera este testigo a bivir a la dicha villa y que dende allí le conosçiera hasta que fallesçiera que avría que hera fallesçido dos años, poco más o menos, y que todo el tiempo que le conosçiera le viera estar casado y tener su casa y asiento en la dicha villa de Moclín. Y que le conosçiera por vista y habla y conversaçión y que avría un año poco más o menos que en la dicha villa de Moclín se repartiere el pecho de la farda de la mar y este testigo seyendo alcalde, de la dicha villa, juntamente con los otros ofiçiales del conçejo de ella, fuera en repartir al dicho Diego de Colmenares e sus hermanos el pecho que les cabía a pagar y que entonçes oyera dezir este testigo al dicho Diego de Colmenares que él y sus hermanos heran omes hijosdalgo e que no devían el pecho que les pedían por ser tales hidalgos. Y que por esto se moviera el dicho pleyto, pero que si heran hidalgos o no, que este testigo lo no sabía, porque los dichos Colmenares no heran naturales de la dicha villa, nin porque nunca oyera en vida del dicho Juan de Colmenares que fuese hidalgo nin lo dexase de ser. E que la dicha villa de Moclín hera franca y en ella no se repartían pechos ningunos, reales nin conçejales, salvo el dicho pecho de la farda de la mar e que en este pagavan todos los vezinos de la dicha villa, pero que si pechara el dicho Juan de Colmenares este testigo lo non sabía ${ }^{16}$.

No les quedaba más remedio a los Colmenares que obtener real provisión receptoria para que Valladolid indagase, por medio de probanza, la filiación de ellos y la nobleza de su linaje —con el costo que suponía - y tampoco era claro que pu-

16 Biblioteca Nacional (BN), Manuscritos, Mss. 11494. Reinando Felipe II aún llegan a las Cortes de Castilla quejas sobre esta exigencia de la demostración nobiliaria de carácter inmemorial, pese a que no se hiciera novedad por la Corona al respecto y se mantuviera lo legislado. Cierto es que en la segunda mitad del siglo XVI la queja, ante los muchos instrumentos escritos conservados y que ya podían ser utilizados, era un tanto extemporánea para la mayoría, pero sí es muestra de esa conciencia de dificultad que sin duda en la Baja Edad Media y comienzos de la Moderna fue real. Dice el capítulo XXXIII de la Cortes de Madrid de 1576: «Otrosí dezimos, que a Vuestra Magestad se significó en las Cortes pasadas, el derecho común tiene dispuesto la forma y calidades que se requieren para provar y concluir la posesión inmemorial. Que era dezir los testigos que así lo avían visto pasar en su tiempo de tantos años a lo menos, y lo mismo lo havían oído a sus mayores y más ancianos y que tal era la pública voz y fama. Que, haviendo de ser verdadero, aún era dificultoso género de provanza...», Cortes de Castilla, Cortes de Madrid de 1576, Capítulos Generales. 
diesen conocerles quienes allende del Tajo nunca los habían visto ni, quizá, habían oído hablar de ellos:

Gonçalo Nieto, vezino de Villanuño, ome pechero que se dixo ser. So virtud del juramento que hizo, dixo que hera de hedad de sesenta años, o poco más o menos. E que al dicho Diego de Colmenares e a sus hermanos no los conosçía sino de ocho días a aquella parte que avía visto y hablado al dicho Diego de Colmenares que le emplazara por testigo, e que paresçía bien el gesto e fisonomía a su padre, Juan de Colmenares, al qual conosçiera, y a Rodrigo de Colmenares, su avuelo, padre del dicho Juan de Colmenares por los ver y hablar e conversar con ellos. Y porque biviera y morara el dicho Rodrigo de Colmenares en el dicho lugar de Villanuño, donde nasçiera y se criara el dicho Juan de Colmenares, padre que dezía que hera del dicho Diego de Colmenares y sus hermanos. E que avía más de quarenta años que, este testigo, començara a conosçer al dicho Rodrigo de Colmenares, seyendo casado y teniendo ya por su hijo al dicho Juan de Colmenares niño pequeño, e bivía e morava en el dicho Villanuño, donde se criava este testigo, e fuera escudero que tenía un par de cavallos los más contino e bivía con el marqués de Santillana... E que al dicho Juan de Colmenares que le conosçiera desde niño, que se criava con el dicho Rodrigo de Colmenares, e después de criado se fue seyendo de quinze años. E más non sabía de Juan, quién nin dónde fuera nin se casara, sino que dezía que se casara en Moclín y fuera alcayde de Moclín y que después que se fuera de aquella tierra, el dicho Juan de Colmenares viniera al dicho su lugar de Villanuño, podía aver hasta diez años, y estoviera allí quinze días e se fuera a donde bivía e después no le avía visto más nin sabía el tiempo que fallesçiera. E que sabía que los dichos Juan de Colmenares e Rodrigo de Colmenares, su padre, padre e avuelo que dezía el dicho Diego de Colmenares que fueran suyos, que fueron omes hijosdalgo... E que veya este testigo que el dicho Rodrigo de Colmenares yva a las guerras que le llamava su señor (el marqués de Santillana, duque del Infantazgo) como hijodalgo y fuera muy garrido hombre de armas. $Y$ que no viera casar a los dichos Rodrigo de colmenares e Juana Garçía su muger, padre y madre del dicho Juan de Colmenares, pero que en todo el tiempo que los viera y conosçiera, los viera este testigo bivir y morar juntamente en una casa, como a marido y muger e ser así público y notorio entre los vezinos del dicho lugar, e viera que estando así ovieran y procrearan entre otros hijos que ovieron, al dicho Juan de Colmenares, llamándole hijo y él a ellos padre y madre, segúnd que esto y otras cosas este testigo lo dixo e depuso en su dicho ${ }^{17}$.

De que esta ley fue utilizada por los concejos contra los nobles quedan abundantes pruebas: una de ellas surgió cuando ante los alcaldes de los Hijosdalgo y el notario del reino de León comparecieron el bachiller Lope de Lodio, procurador fis-

\footnotetext{
17 La sentencia, como el resto de la ejecutoria, fue favorable a los Colmenares y su nobleza, quizá un tanto benévolamente pues sólo un testigo: un hidalgo granadino es capaz con certeza de reconocer de oídas la filiación completa de litigantes, padre y abuelo. Esta apreciación de benevolencia fue en determinados momentos y en instancias superiores atribuida a los alcaldes de los Hijosdalgo de los Reyes Católicos, Carlos I e incluso de Felipe II, a mi juicio y hablando genéricamente de forma no creíble e incierta, no justa, más cuando por ejemplo para este pleito desconocemos la verdadera documentación original completa y tan sólo nos es dado a saber lo que se recogió en la ejecutoria, lo esencial según Derecho. No obstante no fue fácil demostrar la filiación y se percibe de hecho, más aún cuando, como es natural, en la ejecutoria sólo se recogen parte de los testimonios de las probanzas de los vencedores, aquí los hidalgos y éstas no son totalmente fehacientes para nosotros, vistas desde la actualidad, BN, Manuscritos, Mss. 11494.
} 
cal, y Diego de Alcántara, vecino y regidor de Castuera, y presentaron una petición en que dijeron «que los conçejos de las dichas villas e su tierra querían enpadronar e prendar a çiertas personas, por ende que les pedían en nonbre de los dichos conçejos les mandasen dar nuestra carta para las justiçias de la dicha villa e para vos el dicho governador para que diésedes todo favor e ayuda a los procuradores de los dichos conçejos para que pudiesen enpadronar e prendar a los que se desyan hidalgos e se sustrayan de pechar en los dichos pechos reales e conçejales para que pechasen e contribuyesen». La reacción fue favorable, el Ordenamiento Jurídico lo exigía, el 29 de julio de 1504 por la Chancillería de Ciudad Real y en nombre de don Fernando y doña Isabel se expedía real provisión dirigida al gobernador del partido de la Sierra, del maestrazgo de Alcántara, y a los alcaldes y jueces de Castuera, Benquerencia, Monterrubio, Esparragosa y Malpartida con el objeto de que hicieran pechar a estos que se decían nobles y como fundamento jurídico se incorporó traslado de la ley de Juan $\mathrm{I}^{18}$.

¿Protección únicamente entonces o también exclusión de muchos de la condición e inmunidades nobiliarias?

Aparte del hipotético ejemplo de las Montañas y Murcia y del verdadero de los Reyes Católicos y Carlos I en donde al fin los hidalgos salen victoriosos, centrémonos en un caso real y que conocemos plenamente, pese a que sea ya de la Edad Moderna, pero que sirve para incidir en la posterior validez de estas leyes bajomedievales.

Villa de Sabiote, en el antiguo reino de Jaén, diciembre de 1544, allí vivía Lorenzo de la Maestra, el cual se decía hidalgo, pese a que no todos los de la villa estaban en ello, por una u otra razón. Y razón que en cualquier manera no debía estar muy relacionada con el muy improbable deseo concejil de sostener el mantenimiento de la pureza de la nobleza castellana. Lo cierto es que el concejo lo ha-

18 ARChG, Hidalguías, Caja 4493, pz.67. Un año antes hay un ejemplo de un caso intermedio entre ataque y protección a la nobleza por medio de la ley de Juan I: es el acontecido en Alcázar de San Juan a fines del siglo $\mathrm{XV}$, en donde se habían realizado diversos repartimientos, también a inicios del XVI. El mencionado fiscal Lodio y ahora el concejo de la arriba citada villa solicitaron amparo de la Chancillería de Ciudad Real: «que les fazía saber cómo el dicho conçejo tenía repartidos çiertos maravedís entre los veçinos e moradores de la dicha villa, asy para la paga de los casamientos de los Ynfantes como para otros serviçios de que nos avíamos querido servir e para otras cosas e gastos e pleitos. E que munchas personas, veçinos de la dicha villa, se escusavan e se querían escusar de pagar en los repartimientos, asy por ser allegados de vos el dicho prior e justiçias como por otras formas y maneras y escusas que ponían para ello. E que aunque el dicho conçejo los quería prendar por los dichos pechos que les cabían, e mandavan al alguazil que les sacase prendas, que vos el dicho prior e justiçias dávades mandamientos para que no se prendasen, mandando a los cogedores que no cogiesen de las tales personas los dichos pechos, a lo que venía al dicho conçejo e veçinos de la dicha villa grand daño e en nuestras rentas menoscabo». Hidalgos y excusados del prior de San Juan se veían libres de pechos. La Chancillería expidió en favor del fiscal y del concejo de Alcázar de San Juan una real provisión, datada en Ciudad Real a 10 de febrero de 1503 y dirigida a don Álvaro de Zúñiga, prior de la dicha Orden y a sus justicias, para que no se entrometiesen. Pero lo relevante ahora, es que además se les impele a ambas partes a que acaten lo dispuesto en la ley de Juan I, que aquí se comenta, y también en la de Enrique III que se verá a continuación, para que pechasen los que debieran y, por otra parte, fueran inmunes sólo los que según ellas lo mereciesen, ARChG, Hidalguías, Caja 5074, pz.10. 
bía incluido con los pecheros y en consecuencia lo había obligado a contribuir en pechos, por lo cual Lorenzo de la Maestra los demandó, al concejo y al fiscal de la Audiencia, Bracamonte, ante la Real Chancillería de Granada el 17 de diciembre de ese año de 1544, buscando la salvaguardia de su nobleza ${ }^{19}$.

Recibido el pleito a prueba, tras los escritos de demanda y contestación a la demanda, etc, las probanzas se iniciaron por parte de Lorenzo de la Maestra en Sabiote, donde vivía, y en Baeza donde lo habían hecho sus padres y mayores. $\mathrm{Ni}$ el Concejo ni el fiscal las hicieron en el término preceptivo y otorgado, pero publicada la probanza del hidalgo, vieron necesario hacerla, y pedida restitución en forma, se les dio nuevo plazo para que la hicieran.

Hecha pública la última probanza y estando el pleito concluso a espera de la sentencia de los alcaldes de los Hijosdalgo y notario del Andalucía, o bien porque el actor quería asegurar simplemente el reconocimiento de su hidalguía o porque a la vista de lo depuesto por los testigos del concejo y del fiscal temía perder el pleito, por una petición que presentó le fue aceptada como prueba una escritura en la que se contenían datos sobre su nobleza y la de sus mayores, si bien, antes y con visos de sinceridad desesperada en la declaración de la Maestra, éste afirmaba al tribunal, por medio de su procurador:

Que su parte tenía bastantemente averiguado que hera hijodalgo notorio de vengar quinientos sueldos según Fuero de España, nieto e deçendiente por línea derecha de Juan Ruiz de la Maestra, visnieto de Pero Gómez de la Maestra, padre

19 «E contando el caso de ella (de la demanda), dezía que así hera que siendo como hera el dicho su parte home hijodalgo notorio de padre y de agüelo y de solar conoçido de vengar quinientos sueldos según Fuero de España, y en tal posesyón avían estado el dicho Lorenço de la Maestra y los dichos sus padre y agüelo, de veynte, treynta y quarenta y sesenta años y más y de tanto tiempo a aquella parte que memoria de hombres no es en contrario en posesyón vel casy de omes hijosdalgo notorios en la dicha villa de Sabiote y en las otras partes y lugares donde avían vivido y morado y bivían y moravan y de no pechar ny contribuyr en pechos reales ny conçejales en que avían pechado y contribuydo y acostunbraban pechar y contribuyr los omes buenos pecheros de la dicha villa y de las otras partes. Y aviéndose juntado syenpre con los onbres hijosdalgo y teniendo los ofiçios y premynençias de aquellos como hombre hijodalgo notorio y aviendo ydo a nuestros llamamientos que se avían fecho en nuestros reynos a los ombres fijosdalgo y aviéndoles sydo guardadas todas las libertades, franquezas y esençiones que se solían y acostunbravan guardar a los otros fijosdalgo notorios, y aviendo tenido e reputado, su persona, todo, sienpre, como tal fijodalgo.Y en aquella dicha posesyón de hidalguía, las partes contrarias, de poco tiempo a aquella parte, ynjusta y no devidamente, lo avían enpadronado y repartido en los pechos de pecheros, e le avían sacado prendas por ellos, en lo que avían echo fuerça y notorio agravio, por tanto que pedía a los dichos nuestros alcaldes y notario, que avida esta relaçión por verdadera o la parte que vastase para alcançar vitoria en la dicha causa, condenasen y conpeliesen a las partes contrarias, pronunçiasen por tal fijodalgo al dicho su parte, a que le bolviesen y restituyésedes todas las prendas que le avían sacado o el ynterese e valor de ellos. Y que lo quitasen y tildasen de los dichos padrones de pecheros y no le pusyesen más en ellos ni le repartiesen los tales pechos reales e conçejales de pecheros y que le guardasen todas las honras, preminençias y esençiones e libertades que se avían guardado e guardavan y acostunbrado guardar a los otros omes fijosdalgo, como dicho es. E pidió justiçia e costas e juró en forma en ánima de su parte, que la dicha demanda era çierta y verdadera y la entendía provar con testigos y escripturas, e que protestava de suspender el derecho de propiedad, cada y quando conviniese al derecho de su parte. Y si neçesario era y en quanto le convenía y no en otra manera desde entonçes lo suspendía», ARChG, Registro del Sello, Caja 5.736. 
del dicho Juan Ruiz, y ansí hera de los del linaje de la Maestra de la çiudad de Baeça que hera solar, linaje y apellido de notorios hijosdalgo ${ }^{20}$.

Presentó, junto a la petición, escrituras en donde se contenía incluso un pleito de hidalguía sentenciado a favor de su bisabuelo por los alcaldes ordinarios de la ciudad de Baeza, seguía remachando su ascendencia noble. Pero pese a todo no había conseguido que los testigos tuvieran claro que su padre era hijo de Juan Ruiz de la Maestra. El padre del litigante había nacido en Baeza, allí había casado y ya mayor se había trasladado junto a su hijo a Sabiote, los testigos de esta localidad presentados por Lorenzo de la Maestra no tenían certeza de quién era el abuelo, es decir si lo era tal el Juan Ruiz de la Maestra, presentado, ni tampoco sabían si el padre del pleiteante era hidalgo o no, pues en Sabiote no había mostrado abierta intención de ser tenido por tal.

Fallaba el cumplimiento de la ley de Juan I antedicha (NR 2, 11, 7), y de otras leyes que a continuación se comentarán, pero sólo por ahora teniendo presente la de Juan I se aprecia que, por ejemplo, el actor no había conseguido demostrar que él, su padre y abuelo, por veinte años no habían pechado por hidalgos, estaba él, su posible abuelo, pero era evidente que su padre, si en Baeza había sido tenido por hidalgo, no lo había sido — por los veinte años que decía la ley- en Sabiote. Posible abuelo además, pues ni testigos de Sabiote ni testigos de Baeza, por el paso del tiempo, habían dado clara razón del entronque pretendido y recordemos que si bien había aportado escrituras, no lo había podido hacer en cuanto a partidas sacramentales de bautismo y matrimonio, no existían, o testamentos, etc., en donde se diese razón legítima de su ascendencia.

Lorenzo de la Maestra no era un pobre sin posible defensa, era titular de una de las cuarenta lanzas del Rey que había en el Campo de Calatrava, un caballero, y esto mismo que no le hacía pechar también estaba en contra de su presunta hidalguía aunque parezca en principio algo contradictorio, pues para jueces y convecinos podía existir duda sobre si no pechaba por ser hidalgo, además de servir la lanza, o no pechaba sólo por lo último y se encontraban ante un tipo de cuantioso, por lo tanto en principio villano. En otro tiempo, quizá un siglo antes, no hubiera habido duda, cualquier juez lo hubiese dado por hidalgo pues venía o así había indicios, de nobles y se portaba como uno de ellos. En este tiempo, la década de los cuarenta del siglo XVI, las circunstancias habían cambiado. Existía un alto tribunal formado por personal de carrera y letrado, un corpus legal hecho, que los anteriores pensaban aplicar y aplicaban, aunque en estas fechas no siempre con claridad, y existía una sentencia que culminaba el proceso y que en nombre del Rey, en un sólo acto, podía terminar con cualquier presunción de nobleza.

El hidalgo había de ceñirse al proceso y a sus formas y exigencias, Lorenzo de la Maestra no lo había conseguido, el viernes 8 de octubre de 1546 la Sala de los Alcaldes de los Hijosdalgo lo declaraba pechero. Apelado el fallo, los oidores dic-

${ }^{20}$ ARChG, Registro del Sello, Caja 5.736. 
taban nueva sentencia en grado de vista el 4 de mayo de 1548 que confirmaba la dada por la Sala de los Hijosdalgo. La situación se volvía casi imposible para De la Maestra, nueva apelación y nueva sentencia en grado de revista dada por el presidente y oidores de Granada, por la cual el 8 de agosto de 1549 se confirmaban todas las sentencias anteriores: Alonso de la Maestra, fuera en la realidad noble 0 no, era por Derecho pechero y como tal viviría de allí en adelante él y sus descendientes ${ }^{21}$.

Este caso en que el que se tiene por noble no puede ajustar por medio de pruebas su condición y disfrute a los requisitos derivados de la ley fue algo muy común en la frontera del XV al XVI, casi hasta la mitad de este último siglo. Debido, en cuanto a entronques, a mi juicio, sobre todo a dos cosas: a la falta mayoritaria de instrumentos escritos eclesiásticos o privados y a la movilidad social. Aspectos propios, ambos con fuerza, de la Edad Media castellana. Esto, que sirvió para ganar hidalguías por medio de la falsificación, fue también argumento constante por parte de los contrarios a la hidalguía del o los pretendientes a ella, de ahí que en los escritos de contestación a la demanda sea cuestión casi de necesidad que se ataque - bajo diversas fórmulas a lo largo de los siglos hasta el fin del pleito de hidalguía- esta ligazón sanguínea, como consta en el resumen de contestación contenido en una ejecutoria de hidalguía dada en Tudela de Duero en 1426:

Contra lo qual por el mi procurador fiscal e por parte del dicho conçejo, fue respondido que el dicho Alfón Sanches non era parte por sí, ni por los dichos Johán Alfón e Diego Alfón, sus hermanos, nin creyan que de ellos touiese poder. E que el dicho libelo non proçedía, así porque non declarara el nonbre del abuelo... La primera por quanto non sabían nin creyan, antes negaron las dichas partes aduersas ser fijos del dicho Rodrigo Alfón, e puesto que sus fijos fuesen, negaron les ser legítimos. Mas antes dixeron, si neçesario fuese prouarían que non eran legítimos, más que eran en tal manera engendrados e naçidos que non podían nin devían gosar de la dicha fidalguía, aunque los que dixeran sus padre e ahuelo ovieran seydo fijosdalgo 22 .

21 Seis años de gastos personales, económicos, de lucha por ganar el pleito no habían servido para nada, a juicio de los jueces, el Derecho no le amparaba como noble sino como pechero, y como colofón la honra mancillada ante todos, cosa esencial en ese tiempo, y la imposibilidad por el momento de que los de su linaje pudieran acceder con nobleza y dinero a los puestos más altos de la Monarquía. Por lo que se refiere a los gastos económicos estos fueron siempre importantes, pese a que se tuviera dinero como Lorenzo de la Maestra, y gastos económicos que se recrecieron al fin del proceso pues con la sentencia en revista se le condenó a las costas y sólo las del concejo ascendían a 6.089 maravedís. La ejecutoria a favor del Concejo de Sabiote se libró en la Chancillería granadina el 30 de enero de 1550, en su archivo quedaría para siempre la pechería de los De la Maestra, duro fielato a superar aún en el hipotético caso de que un descendiente de Lorenzo de la Maestra consiguiera años después demostrar fehacientemente el entronque con los nobles hidalgos de la Maestra de la ciudad de Baeza. La ejecutoria en ARChG, Registro del Sello, Caja 5.736.

22 Es claro: ataque a la falta de abuelo; esparcimiento de dudas sobre el origen sanguíneo; e ilegitimidad en caso de demostrarse la línea, que hace imposible según Derecho la herencia de la nobleza, ARChG, Pergaminos, n. ${ }^{\circ} 44$. El Derecho Común y especialmente el Canónico hacía ya, parece, imposible la transmisión de la hidalguía, que el Fuero Viejo permitía a lo hijos de barragana, si así lo tenía por bien su padre sin otras actuaciones jurídicas. No obstante sabemos, no en el caso de los ilegítimos, pero sí en los naturales que según diversas circunstancias normativas se permitió hasta el fin del Antiguo Régimen esta transmisión, si bien siempre tuvo enemigos ideológicos y doctrinales e incluso legales. Otro 
No obstante la ley de Juan I (NR 2, 11,7) en ocasiones fue interpretada y utilizada como favorable a los hidalgos, como ella misma se postulaba, pretendiendo los que habían sufrido el atropello de sus exenciones hacer recaer la carga de la prueba en el concejo y no en ellos, como en apariencia parecía pretender la ley de Juan I de 1384 y esto se llega a practicar incluso en el siglo XVI, aunque ya excepcionalmente y con la intención de hacer salir al pleito a un concejo que prenda o hace contribuir al hidalgo pero que se niega a presentarse a litigio aunque esté demandado por el agraviado. Aspecto diferente es que el tribunal chancilleresco accediera a las pretensiones del hidalgo.

Los hidalgos llegaron a solicitarla y se hacía constar tal solicitud por la Corte, seguramente a modo de advertencia al concejo, pero la Chancillería no acostumbraba a expedir provisión conteniendo la ley de Juan I de 1384 - utilizaba usualmente la posterior y más completa de Enrique III - sino que se limitaba a hacer constar la petición hidalga y a otorgar sobrecarta de emplazamiento con mayores penas. Un ejemplo de esto se contiene en una sobrecarta de una real provisión dada por los alcaldes de los Hijosdalgo en 7 de febrero de 1540 dirigida al concejo del lugar del Puerto, jurisdicción de la ciudad de Trujillo, por la que se le notificaba que Alonso Díaz, vecino de dicho lugar, había puesto demanda al concejo y al fiscal sobre su hidalguía, y que en su momento se le había dado provisión de emplazamiento:

La qual paresçió que vos fue notificada en vuestro ayuntamiento e paresçió que dentro del término en ella contenido ni después de él no enbiastes al dicho vuestro procurador en seguimiento de la dicha causa. E por parte del dicho Alonso Díaz vos fue acusada la rebeldía e por su parte fue presentada una petiçión en que efeto dixo que pues no enbiávades vuestro procurador en seguimiento de la dicha causa que nos pedía y suplicava le mandásemos dar nuestra carta e provisión, ynserta la premática del señor Rei don Juan, que aya Sancta Gloria, condenándovos en las costas que sobre ella su parte abía fecho i que ello proveyésemos como la nuestra merçed fuese. Lo qual por los dichos nuestros alcaldes e notario visto, fue acordado que devíamos mandar dar esta nuestra sobrecarta de la dicha nuestra carta de enplazamiento para vos sobre la dicha razón, e nos tovímoslo por bien. Porque vos mandamos que del día que con ella fuéredes requeridos, estando juntos en vuestro ayuntamiento, segund que lo avéys de uso e de costumbre fasta quinze días primeros siguientes enbiéys a la dicha nuestra Corte e Chançillería ante los dichos nuestros alcaldes e notario vuestro procurador sufiçiente ${ }^{23}$.

ejemplo posterior, de 1519: «Lo otro, caso que lo fueran lo qual no heran, ni devían de gozar de las libertades y esençiones conçedidas a los hijosdalgo porque no heran hijos legítimos del que dezían que hera su padre, ni él fuera hijo legítimo del que dezían su avuelo. Antes fueran y heran espurios, nasçidos de dañado ayuntamiento, en tal manera que no pudieran ni devieran gozar de las dichas esençiones», BN, Manuscritos, Mss. 11494.

${ }_{23}$ ARChG, Registro del Sello, Caja 5.646. Otro ejemplo idéntico y de igual fecha ocurre en Madridejos. Francisco de Vega, vecino de esa localidad, había sido prendado por el Concejo, lo que había denunciado ante los alcaldes de los Hijosdalgo y notario del Reino de Toledo, éstos le dieron carta emplazando al Concejo pero el cabildo hizo caso omiso. El hidalgo volvió a la Chancillería y obtuvo una sobrecarta que contenía la real provisión de emplazamiento primigenia, además acusó a Madridejos de rebeldía por no aparecer ante el primer emplazamiento que le había sido notificado en su ayuntamiento, pero no sólo eso, sino que pidió se le diese traslado de la pragmática del rey don Juan I, además de las 
Como se puede apreciar, corroborando lo expuesto, el tribunal no concedió provisión inserta la ley de Juan I, sino que reafirmó el emplazamiento previo ahora con mayores penas, aunque para obligar aún más a la presentación de la parte municipal se añade una pena complementaria pues se condena al concejo a que cada oficial pagase un ducado a Alonso Díaz por las costas que había sufrido por no haber enviado el procurador en su momento.

Continuaban existiendo muchas excepciones que excluían de la justicia real y de sus Audiencias el conocimiento de los pleitos de hidalguía, de ahí que perseveren los intentos regios por atraer a sí en solitario las causas de hidalguía convertidas en casos de Corte. La norma de Juan I de 1379, eslabón importantísimo al convertir al pleito de hidalguía en caso de Corte, no deja de ser una ley medieval envuelta en las peculiares características histórico-políticas de la Castilla del siglo XIV. Eso implicó que su observancia no fuese de estricto y general cumplimiento, ya fuera por causas basadas en la costumbre y el uso arraigado, por causas establecidas a partir de la misma movilidad y habitual lejanía geográfica de la Corte medieval con respecto al pleiteante, o ya fuera por causas basadas en determinados localismos o incluso en privilegios regios que establecían salvedades ${ }^{24}$.

Juan I con su ley de 1379, convirtiendo en caso de Corte el proceso contencioso para dirimir la nobleza como cuestión de fondo, establece un hito importantísimo pese a que durante mucho tiempo tuviera que convivir con otras prácticas como se acaba de ejemplificar ${ }^{25}$. Otra de sus leyes ${ }^{26}$, concretamente la que se ocupa de quién debe pechar o no y que sin pleito el concejo o cualquier otra universidad, justicia u oficiales fiscales esté obligado a guardar las inmunidades a los hidalgos que cumplan los preceptos de la ley y no sólo sus inmunidades sino también todo tipo de franquezas que les correspondan es igualmente significativa, pues en principio supone la salvaguarda regia de los derechos nobiliarios con carácter erga omnes y en realidad supuso la exclusión de la protección monárquica de un buen número de nobles que quedaban a merced de la actividad concejil,

costas, pues si no habían hecho caso a la demanda, los oficiales, era porque se había avasallado injustamente su hidalguía protegida por semejante ley. La real provisión se expidió volviendo a emplazar al Concejo el 7 de febrero de 1540, Idem.

24 Ya se vio como el corregidor de Medellín actuaba conociendo los pleitos de hidalguía pese a ser casos de Corte, otro caso sucede en la entonces villa de Cáceres. El procurador de los buenos hombres pecheros, ante los alcaldes de los Hijosdalgo y notario de la provincia de León, presentó una petición diciendo que habiendo muchos pecheros que ahora se decían hidalgos, a los que su parte los había hecho prendar, el concejo y regidores, que apoyaban a los que se decían exentos, mandaron que se les devolviesen las prendas tomadas en grave detrimento de la república. Aunque más grave era aún que se habían arrogado la potestad jurisdiccional de «conoçer de pleytos de fidalguías, pronunçiando por omes fjosdalgo algunas de las personas a quien los dichos sus partes avían prendado, no lo pudiendo fazer, perteneçiendo el conoçimiento de ello a los dichos nuestros alcaldes e notario». En la ejecutoria en donde se condena al concejo y a los regidores, dada el 8 de enero de 1504, se insertaron las leyes de Juan I —en ésta sólo lo concerniente a quiénes habían de pechar-, y completa la de Enrique III, ordenándoles perentoriamente que las cumpliesen y que no conociesen nunca más de pleitos plenos de hidalguía, ARChG, Hidalguía, Caja 4493-72b.

25 NR 2, 11,12.

26 NR 2, 11, 7 . 
lo que permitió a la postre que aumentara la conflictividad social de las localidades en lugar de apaciguar las relaciones de los nobles con los villanos que dominaban el concejo.

Pero que estas disposiciones no tuvieran mucho éxito, en la práctica, bajo su reinado no las devalúa a largo plazo, supieron imponerse al fin de la Edad Media y a comienzos de la Modernidad a mano de sus más grandes sucesores y postreros titulares de su dinastía: los Reyes Católicos.

\section{b) Enrique III: perfeccionamiento de la legislación de Juan I}

Posiblemente Juan I sea el gran olvidado historiográficamente en el iter del pleito de hidalguía y su relación con la Corona y esto no corresponde a un juicio certero, equilibrado y ecuánime. Y es que pese a que cerca de 1805 , cuando De la Reguera Valdelomar crea la Novísima Recopilación (Nov.R.), este recopilador ponga como ley que abre el Título XXVII del libro XI, la ley de Juan I de 1379, su no efectivo cumplimiento por parte de los contemporáneos al rey posiblemente haya hecho que la historiografía minusvalore esta norma, junto al triunfo de otra muy similar pero ya no de Juan I.

Y es que su hijo y sucesor, el rey Enrique III, daría otra ley que sí tendría éxito, por su eficacia, tanto en su tiempo como hasta el fin del Antiguo Régimen, ya en el siglo XIX. Y en buena parte esta norma que perfecciona la de Juan I de 1384, fue causa del casi «olvido» de la ley paterna que se acaba de analizar.

Sin dejar de ser cierto lo dicho con respecto a la efectividad de las leyes de Juan I entre sus contemporáneos, no se puede ser absoluto, las leyes del mismo Enrique III que terminaron recopilándose en NR 2, 11, 9 indican que el pleito de hidalguía como caso de Corte y por tanto visto en la Audiencia Regia fue ganando adeptos desde que así lo instituyó Juan I, y por lo tanto evidencia también que frente a la práctica privada o local para dirimir quién es o no hidalgo, había aumentado y se había hecho hasta cierto punto habitual la vertiente pública que implicaba la intervención del órgano jurisdiccional, pero no ya uno cualquiera, sino la Audiencia, superando así también localismos, y esto último en dos sentidos pues ya no sólo se conoce en abundancia por los concejos y las justicias locales, lo que ya se ha dicho pervive, sino que los mismos concejos, despojados de autoridad, se han convertido o se pueden convertir obligatoriamente en un simple parte, inclusive contra su voluntad, ante la Audiencia y en primera instancia. En resumen, parece indicar la ley enriqueña que las medidas de Juan I no sufrieron un fracaso absoluto desde su inicio. Dice la ley recopilada, conformada por las de Enrique III:

En las dichas ciudades, villas y lugares ay muchos homes que se dizen que son hijosdalgo por se escusar de pechar y dizen que están en posesión de hijosdalgo y que traen pleitos pendientes en la mi Corte ${ }^{27}$.

27 Idem. 
Señal, ésta, de que existía un número relevante de pleitos de hidalguía como casos de Corte ya en tiempos de Enrique III, pero evidencia igualmente de cierta preocupación de los concejos ante la protección de los derechos de los hidalgos por un ente jurisdiccional superior a ellos y que les perjudica ostensiblemente, por ejemplo al utilizar en su favor el pretendido hidalgo la litispendencia para no pechar, pues hasta la sentencia la duda sometida a juicio les favorecía para gozar de las facultades de la nobleza y por tanto no contribuir al fisco y así eran amparados los litigantes por patentes dadas por los magistrados de la Audiencia Regia.

Enrique III une su egregio nombre a los pleitos de hidalguía por varias normas, pero significativamente por la que se vino a denominar en estas controversias como la pragmática enriqueña. Una de las leyes medievales de mayor éxito, que incluso cuando a fines del XVII parecía destinada al ostracismo, es de nuevo rescatada en el inicio del XVIII por Felipe V en su auto de $1703^{28}$.

28 Realmente pese a la intervención o los intentos de ella, por parte de las Chancillerías, para controlar los recibimientos sin contradicción de hidalgos o las continuaciones de hidalguía en los concejos castellanos, hay que afirmar que estas prácticas nunca terminaron de escapar a la férula jurisdiccional local. Incluso la legislación, muy posterior, de Felipe $V$ a la que se ha hecho mención y que he trabajado en DÍAZ DE LA GUARDIA Y LÓPEZ, L.: «La hidalguía a fines del Antiguo Régimen. Los Apuntamientos del granadino Antonio de Orejón y Haro: Estudio y edición», en ETF. Serie IV (Historia Moderna), n. ${ }^{\circ}$ 20, en imprenta, digo, que las medidas de Felipe $V$ reconocieron la importancia de los concejos en estas actuaciones jurídicas, si bien la intentaron someter al control de las Chancillerías, cosa que posiblemente consiguieron mayoritariamente, y asegurar su limpieza por medio de la actuación del fiscal, cosa ésta ya no tan ciertamente conseguida, gracias, entre otras cosas, a la falsificación de los medios de prueba. Lo que no era desconocido por parte de los mismos fiscales, como se queja Elizondo en su Práctica Universal Forense. Pero la falsificación y manipulación de testimonios y pruebas ni es sólo propia de las actuaciones sobre hidalguía, ni seguramente, si se estudiase estadística y fiablemente, fuese en donde más la hubo, aunque sí en donde, quizá, más preocupación social y después historiográfica despertó y despierta. ¿Y por ejemplo en los mayorazgos y en otras vinculaciones, y sus pleitos? Litigios, posiblemente más abundantes que los de hidalguía, de los que apenas se dice nada y en los que se jugaba dinero contante y sonante de por vida y por generaciones. ¿Acaso en ellos no se producían falsos testimonios e instrumentos? Precisamente la cuestión de Cortes comentada arriba sobre la demostración de lo inmemorial, no está dirigida a los pleitos de hidalguía sino en concreto a los de mayorazgos, aunque sirva para ambos. Más largamente dice el Capítulo XXXIII de las Cortes de Madrid 1576: "otrosí dezimos, que a Vuestra Magestad se significó en las Cortes pasadas, el Derecho Común tiene dispuesto la forma y calidades que se requieren para provar y concluir la posesión inmemorial; que era dezir los testigos, que así lo havían visto pasar en su tiempo de tantos años a lo menos, y lo mismo havían oido a sus mayores y más ancianos, que ellos lo havían visto, y nunca cosa en contrario, y que tal era la pública voz y fama; que haviendo de ser verdadero, aún era dificultoso género de provanza, lo qual duró hasta que la Ley de Toro, queriendo dar forma que havía de haver en las provanzas de los mayorazgos y sucesión dellos, quando por escrituras no se pudiese provar, declaró que se provase la dicha inmemorial diziendo lo mismo que arriba está dicho, y añadiendo a ello otras segundas oidas; que no fueron de más efecto, que de hazer de la dicha inmemorial se prueve de ordinario, con labradores y gente ignorante, y que los que no lo son, no se abrevan con sus conciencias a deponer de las dichas segundas oidas; porque aunque acaece ver un hombre una cosa y haverla oido a sus padres y nunca cosa en contrario y ser así público, por maravilla de los padres y mayores, dizen haverlo oido a otros sus mayores, sino que verdaderamente los receptores y escrivanos, quando sucede el caso, para alargar la escritura, ponen lo inmemorial, no solo con las dichas segundas oidas, que no hay, pero aún con terceras, cosa tan imposible quanto se dexa entender. Y para remedio dello y excusar perjuicios y que los receptores no fuesen dueños de dar o quitar la justicia a las partes, se suplicó a Vuestra Magestad mandase que la dicha inmemorial fuese provada concluyentemente en la forma que el Derecho Común tiene dispuesto, y Vuestra Magestad respondió, no convenía hazerse en ello novedad; con lo qual lo susodicho queda sin remedio, siendo tan necesario. A Vuestra Magestad suplicamos lo mande considerar como cosa que tanto importa, y sea ser- 
Se trata en realidad de dos mandatos refundidos en uno, el fundamental fue dado en Toro en 1398, una pragmática, y ésta fue completada por sobrecarta dada en Tordesillas a 14 de abril de 1403, conformándose la llamada pragmática enriqueña que se conoce a través de NR 2, 11, 9 y Nov R 11, 27, 2.

Ley que surge según su exposición de motivos como instrumento frente a los hidalgos creado a petición y en favor de los concejos castellanos que se quejaban del gran número de los que se llamaban nobles y a la vez de las argucias jurídicas que muchos utilizaban para no pechar:

A los oidores de la mi Audiencia y alcaldes de los Hijosdalgo y sus lugarestenientes y a todos los alcaldes y juezes de todas las ciudades, villas y lugares de mis reynos: sabed que muchos Concejos de estas ciudades, villas y lugares se me han embiado y embían cada día a querellar, diziendo que en las dichas ciudades, villas y lugares ay muchos homes que se dizen que son hijosdalgo por se escusar de pechar y dizen que están en posesión de hijosdalgo y que traen pleitos pendientes en la mi Corte y que hasta ser los tales pleitos determinados por sentencia que no deven pechar ni pagar y aun dizen que vos los dichos mis oidores y alcaldes de los Hijosdalgo y algunos de vos que les avedes dado y dades mis cartas para que no sean prendados hasta que por sentencia sean determinados los dichos pleitos. En lo qual dizen que a todos los pecheros viene muy gran daño y fueme pedido proveyese de remedio ${ }^{29}$.

Los concejos evidentemente habían seguido haciendo pechar o en su caso prendando a todo aquel que a bien tuviesen, aunque basados en la ley y sobre todo en sus Fueros y costumbres y por encima de todo en sus intereses, y frente a las posibles quejas de los agraviados se habían limitado a no hacer caso - lo que podía mover pleito sobre la exención avasallada - o a llegar a determinados acuerdos con los interesados. Sin embargo cuando se tenía enfrente a grupos sólidos de personas que se decían nobles y que estaban bien coordinados, formando Estado, la situación cambiaba y más si entre ellos había poderosos política y económicamente.

Ya se ha indicado a quién va dirigida la pragmática enriqueña y quién solicitó esta medida, pero qué hizo el legislador. Enrique III dispone en 1398 lo siguiente:

1. Les deben ser guardadas sus franquezas y libertades a los hijosdalgo notorios de solar conocido que por tanto estén en su posesión e igualmente a hidalgos que tras pleito hubiesen tenido sentencia o sentencias en su favor cumpliendo con la ley de Juan I de 1379 (NR 2, 11, 12) y que tras ella $o$ ellas estuviesen en posesión de su nobleza.

vido de mandar y ordenar lo que cerca desto está suplicado, para que los dichos perjuicios cesen. A esto vos respondemos que por ahora no conviene hazer en esto novedad" Cortes de Castilla, Cortes de Madrid de 1576, Capítulos Generales.

${ }^{29}$ NR 2, 11, 9. 
2. De la misma forma, no pecharán las mujeres viudas de hidalgos mientras que no se vuelvan a casar o las hijasdalgo viudas que aunque en su momento casaren con pecheros, mantengan esa viudedad.

3. Todas las demás personas no comprendidas en las circunstancias anteriores deberán pechar.

4. Por lo que respecta sobre todo a los contenidos en el primer punto, en cuanto se les entable pleito de hidalguía deberán pechar mientras dure el mismo pese a que aleguen ser hidalgos y estar en posesión de tales.

5. El principio antecedente queda roto sólo si a la persona o personas a las que se les hubiese demandado su hidalguía pudiesen atestiguar que su padre y abuelo fueron vecinos de la localidad en donde se les había emplazado a pleitear su nobleza y que en ella nunca pecharon a fama de hidalgos y no por otra circunstancia o razón. En este caso tampoco deberían pechar mientras que durase el pleito que se les había entablado.

6. Se dejan en su fuerza las sentencias a favor de personas que se decían hidalgos que se hubieran ganado siguiendo procedimientos y circunstancias secundum legem con anterioridad, se entiende a la ley de Juan I de 1379 y a la nueva ley de Enrique III, y a los que se dijeran hidalgos en virtud de ellas, siempre que en ese momento, 1398, estuviesen gracias a tales sentencias en posesión de hidalgos.

7. Si en contra de lo dicho en la ley se hubiesen tomado prendas o se hubiese hecho pechar, se ordena que los concejos y universidades devuelvan lo tomado y no pasen nunca más contra ello.

8. Se recalca como única jurisdicción competente sobre los pleitos y temas de hidalguía a la regia y concretamente a la de los alcaldes de los Hijosdalgo, a donde deberán recurrir en busca de su derecho los concejos, personas o universidades sin que puedan conocer en sus jurisdicciones de estas materias (Este último precepto según la Nueva Recopilación pertenecía a la sobrecarta de Tordesillas de 14 de abril de 1403).

Conocido el contenido de la ley, destacar en primer lugar que el rey Enrique III había otorgado un gran y útil instrumento a favor de los concejos de sus reinos y que desde luego sería utilizado por ellos. Y para entender la eficacia y ejercicio de la pragmática enriqueña estúdiese su final pues en cierta forma queda un poco descolocado del resto del contenido de la misma.

Como se ha dicho el pleito de hidalguía y lo a ello tocante se había convertido en caso de Corte por parte de Juan I y también se ha dicho que esta norma debió tener cierto cumplimiento desde un primer momento, sobre todo por parte de los hidalgos, pues la misma pragmática enriqueña en su exposición dice que los concejos habían recurrido ante el Rey pues muchos de ellos topaban con estos pleitos 
entablados en su Corte cuando intentaban hacer pechar a alguien. Que esto sea cierto no creo que haya duda, aunque es verdad que no hay documentación cuando menos la desconozco- para saber cómo y hasta dónde esto acaeció y que sólo se puede intuir por testimonios como esta ley u otras, es decir por testimonios quizá indirectos. Eso no quiere decir que se cumpliera siempre y menos por otras jurisdicciones como la concejil.

De ahí que Enrique III en 1398 vuelva a ordenar que sea su justicia la que conozca y en concreto unos de los jueces de su Corte, sus alcaldes de los Hijosdalgo. Mandato importante, pues si bien Alfonso $X$ parece que creó a los alcaldes de los Hijosdalgo y que Enrique II estableció que dos alcaldes de los Hijosdalgo permanecieran en su Corte, realmente no es conocida su competencia por completo y más cuando de la ley de Juan I de 1379 parece entenderse que no poseían la competencia exclusiva y excluyente en pleitos de hidalguía. Será ahora con esta pragmática de Enrique III cuando definitivamente adquieran tal competencia en solitario, desde entonces para que el pleito de hidalguía se realice conforme al Derecho territorial de la Corona éste deberá ser visto por unos jueces especiales, no ya unos cualesquiera de la Corte regia, sino por los alcaldes de los Hijosdalgo en exclusiva.

Los concejos nunca recibieron bien que los asuntos de hidalguía, que tanto les afectaban, escaparan de sus competencias, lo que se plasmará claramente en los inicios de la Edad Moderna. El concejo es una institución fuerte a lo largo de nuestra Edad Media y Moderna, y todavía más, en cuanto a su independencia, lo debió ser durante el Medievo. Sin olvidar que, durante el siglo XV e inicios del XVI, al incardinarse definitivamente en el aparato burocrático de la Monarquía como institución fundamental, el concejo, a la vez y por ello, pierde independencia y poder al consolidarse como pilar del Estado moderno. La cuestión como es sabido no fue fácil y necesitó de una evolución, que por ello, como proceso, no sólo sufrió avances sino aparentes retrocesos, pugnas, violencias y fricciones hasta alcanzar la Modernidad y a la vez durante ella. Entre estas resistencias del municipio a abandonar funciones a la vez que se moderniza con y en el Estado, está su oposición a perder competencias jurisdiccionales y en ellas las de hidalguía ${ }^{30}$.

30 Los concejos como ha resaltado la historiografía, fueron útil fuente para ennoblecerse, unas veces según Derecho y otras no, cosa ésta que no suele ser atendida por contra por la historiografía que tiende a la generalización, no sin un fondo de verdad, es evidente. Pero sigo pensando que hay que ser más cautelosos con esto y que los ejemplos a veces sonoros otras no, deben ser revisados no sólo en cuanto a líneas sanguíneas y genealogías sino conforme a Derecho pues de ello se hablaba y se trataba. No obstante no se pueden negar evidencias, pero sí matizarlas pues a veces pueden, estas matizaciones, dar una visión más correcta del problema. Problema que tiene más de una vertiente y, si se me permite, moneda a la que nobiliaristas de antaño e historiadores de ahora suelen verle sólo una de sus caras. Es más, creo que se deberían atender con mayor atención, sin menoscabar como se acostumbra el Derecho por lo que toca a resultados finales, las resistencias —basadas también en Derecho, no sólo en la política o en los hechos- que soportaron muchos de estos intentos de utilización de las instituciones concejiles para ennoblecerse, aquí sí me refiero, de forma fraudulenta. La gente no quedaba impasible, ni muchas comunidades. Sirvan de muestra entre, muchísimas, tres tipologías reiteradas en la documentación. La denuncia general ante el Rey y el Consejo: «Alexo Hurtado, vezino y regidor de la villa de 
Ni Juan I ni Enrique III consiguieron realmente que los casos contenciosos de hidalguía se tuvieran por todos, también por otras jurisdicciones, como exclusivos casos de Corte en donde la Audiencia Real y los alcaldes de los Hijosdalgo fueran los únicos a conocer y es que hasta bien entrado el gobierno de Carlos I se encuentran ejemplos en donde una y otra vez los concejos e incluso los corregidores son requeridos por las Chancillerías para que se desentiendan en sus juzgados de recibir para sí este tipo procesal, no así cuando se trate incidentalmente la hidalguía. Veamos una sobrecarta de los Reyes Católicos — dada la primera a petición del Común y hombres buenos de Alcaraz- atendiendo a lo primero, al conocimiento de los pleitos plenos de hidalguía, que además, por otra parte, está directamente relacionada con la oposición de muchos y de las instituciones también, a que los concejos se convirtiesen en medio, juez y parte de noblezas.

Don Fernando e doña Ysabel, etc. a vos Gonçalo de Caravajal, nuestro corregidor en la çibdad de Alcaraz e a vos el bachiller Rodrigo de Figueroa, alcalde mayor en la dicha çibdad e a otros qualesquier alcaldes e justiçias de la dicha çibdad a quien ésta nuestra sobrecarta fuere notificada, salud e graçia. Sepades que en la nuestra Corte e Chançillería que resyde en Çibdad Real ante los nuestros alcaldes de los Fijosdalgo e notario de Toledo pareçieron el bachiller Lope de Lodio, nuestro fiscal, en el nuestro nonbre, e la parte del común e omes buenos pecheros de la dicha çibdad e presentaron ante ellos una petiçión por la qual dixeron que bien sabían como avían quexado ante ellos de vos el dicho nuestro corregidor e alcalde porque no queriades ni aviades querido dar favor e ayuda a los dichos pecheros para notar e enpadronar e prendar a çiertos veçinos de la dicha çibdad que se querían subtraer de pechar en los pechos de pecheros disyéndose omes fijosdalgo, se-

Uclés y en nonbre de ella, cuyo poder no muestra, dio una petiçión a Su Magestad que no está firmada de nadie, en que por ella dize que en la dicha villa ay muchos hidalgos que tienen usurpado el patrimonio real a causa de que mañosamente se juntaron çierta cantidad de honbres y hizieron que los enpadronasen y çitaron al conçejo y haviendo hecho çiertas provanças y sentençiadose los dichos pleitos y pasadose los quatro años de la restituçión, sacaron cartas executorias. Suplica atento que el conçejo de la dicha villa ni el fiscal no hizieron provanças ni diligençia alguna y que algunos hermanos de los dichos hidalgos son pecheros se les dé çédula para que las executorias de hidalgos de la dicha villa, en que el dicho conçejo ni el fiscal no ubieren hecho provanças, se les abra la puerta a pediles de nuebo sus exsençiones porque el audiençia no quiere admitir al conçejo si no es en la filiaçión. Al margen: Sigan su justiçia. Cavala», es ésta una consulta vista el 2 de marzo de 1576, AHN, Consejos, Leg. 7043. Otra segunda tipología es aquella que atiende a un caso concreto y que se eleva también por encima de las Chancillerías. Es una consulta de 1 de diciembre de 1581: «Juan Gómez de Bedoya, en nombre de la çiudad de Chinchilla sin presentar poder, dize que el fiscal y el conçejo su parte tratan pleito en la Chançillería de Granada con Juan de Barrionuevo y Clemente de Barrionuevo y otros sus consortes, veçinos de la dicha çiudad, sobre su ydalguías y por ser pleito de muchas importançia y calidad pide se mande dar çédula real para que se vea por dos Salas». La respuesta fue; «No a lugar», AHN, Consejos, Leg. 7046. Es cierto que el rey y sus consejeros no solían aceptar las peticiones, entendiéndolas como intromisiones en las estructuras jurisdiccionales establecidas y excepciones, por tanto, no convenientes de hacer. De forma que remitían, a través de la negación o de la frase «sigan su justicia», a los solicitantes ante los tribunales convenientes: las Chancillerías. Por último, sobre todo en el reinado de los Reyes Católicos y Carlos I y Juana I se interponen demandas a muchísimos hidalgos de una misma villa ante las Chancillerías y no siempre, como demuestran después las actuaciones, para hacerse con la hidalguía por medio de la ejecutoria gracias al favor de la parte concejil. Hubiese sido mucho más fácil quedar directamente empadronados en sus villas aprovechando las connivencias con el concejo, que siempre se suelen ver por los historiadores en estos casos, lo que hubiese sido menos peligroso y más barato que un verdadero pleito en donde el fiscal, pese a la dejación del concejo, podía ser muy duro. 
yendo pecheros, fijos e nietos de pecheros. Antes vos avíades entremetido e entremetíades a conosçer de las dichas cabsas de fidalguías no lo pudiendo haser, sobre lo qual os avía sydo dada nuestra carta, su thenor de la qual es éste que se sygue $^{31}$. E que no enbargante que con la dicha nuestra carta vos el dicho alcalde avíades sydo requerido que la cunpliésedes e que diesesdes favor e ayuda a los dichos pecheros para enpadronar e prendar a los que asy se desyan fidalgos en ella nonbrados, que no lo avíades querido fazer ni conplir lo en ella contenido. Antes, avíades puesto a ello vuestras escusas, entremetiéndovos a conosçer de las dichas cabsas para ver quién hera fidalgo o no, e quién devía ser prendado por los dichos pechos, según pareçía por un testimonio que ante ellos fasyan presentaçión. Por lo qual devíades ser condenado en las costas que avyades de ser condenado en todas las costas que se avían fecho en se enbiar a quexar de vos ante ellos e asymismo en las penas en la dicha nuestra carta contenidas por no cunplir lo en ella contenido e aver ydo e pasado contra las leys e premáticas de nuestros reynos porque les pidieron que sobre ello les proveyesen de remedio con justiçia mandado dar nuestra sobrecarta contra vos el dicho alcalde, por la qual nos mandásemos que pareçiesedes a vos ver condenar a ser aperçivydo e ynformado en las penas en ella contenidas. Mandándovos ansymismo so mayores penas que cunpliesedes la dicha nuestra carta, según que en ella se contenía. Mandando a vos nuestro corregidor e alcaldes que no vos entremetiésedes a conosçer a los dichas cabsas de fidalguya en propiedad ni en posesyón. Salvo que en esto fuese a dar favor a los dichos pecheros para que pudiesen enpadronar e prendar a los que asy se desían fidalgos en la dicha carta nonbrados. En lo qual administraréis justiçia. E por los dichos nuestros alcaldes e notario vista la dicha petiçión e asymismo el dicho testimonio contenido, proveyendo sobre lo en ella contenida mandaron dar e dieron esta nuestra sobrecarta para vos en la dicha razón. E nos tovímoslo por bien: por la qual mandámosvos, el dicho corregidor e alcaldes e justiçias e cada uno de vos que veádes la dicha nuestra carta, en esta nuestra carta encorporada, e vista la guardades e cunplades e fagades e mandades guardar e conplir en todo e por todo según e como que en ella se contiene, e guardándola e cunpliéndola. E contra el thenor e forma de lo en ella contenido no vayays ni paseys ni consyntases yr ni pasar por alguna manera, no vos entremetiendo a conosçer ningunos casos de los pleitos de fidalguías en propiedad ny en posesyón, salvo en quanto fuere a dar el dicho favor a los dichos omes buenos pecheros para lo contenido en la dicha nuestra carta. Ca vos en quanto al dicho conoçimiento por la presente vos ynibimos e damos ynibidos según que en la dicha nuestra carta se contiene. E los unos ni los otros non fagades ende al por alguna manera so las penas en la dicha nuestra carta contenidas e de otros çinquenta mil maravedís para los estrados de la nuestra Abdençia. So la qual dicha pena, etc. Dada en Çibdad Real a XXIII de otubre de mil quinientos tres años ${ }^{32}$.

Ejemplos relevantes de esto recorren muchísimas localidades hasta por lo menos los primeros cuarenta años del siglo XVI, para, por el contrario, conforme avanza esta centuria y ya durante el reinado de Felipe II sean asuntos que no suelen aparecer en los documentos, quizá haya alguna excepción pero desde luego no representativa cuantitativamente hablando. Varios han sido los ejemplos, pero uno conocido y destacado por los problemas y resistencias que trajo, así como por la importancia de la localidad, fue el de la ciudad de Córdoba, en

\footnotetext{
31 El registrador dejó en blanco el espacio.

32 ARCHG, Hidalguía, ARChG Caja 4493, pz.50.
} 
donde los concejos pese a la ley de Juan I y las posteriores y en especial la de 1492 de Córdoba, y los mandatos de la Chancillería, seguían con el empeño de dirimir los pleitos de hidalguía, incluso, tras lo dicho, en tiempos del mismísimo Felipe II, lo que sí hace más importante cualitativamente hablando esta testaruda actitud $^{33}$.

En cuanto al resto del contenido de la llamada pragmática enriqueña los puntos aquí extractados números primero, segundo y sexto establecen a quiénes se les debe guardar la inmunidad fiscal y las demás franquezas y libertades de la hidalguía ya hubiesen ellos o sus mayores litigado y ganado la conservación de su posesión conforme a la ley de Juan I o bajo las costumbres, usos y normas que antes de ésta regían estos contenciosos. Cómo no, quedan también comprendidos en esta posesión aquellos hidalgos que tenidos por tales, nunca, ellos ni sus familias, habían sido inquietados en su posesión, los notorios según la costumbre. De la misma forma se atiende a la situación de las mujeres, ya sean hijasdalgo y viudas de pecheros, o hijasdalgo o no pero viudas de hidalgos ${ }^{34}$. En principio parece esto una explicación y precisión de la ley de Juan I que trataba de lo mismo, pero hay importantes diferencias. En la ley de Juan I la carga de la prueba parece estar en manos del concejo, pues a estos se les ordena que a los comprendidos en la ley se les guarden bajo diferentes penas sus derechos. Con Enrique III todo

${ }^{33}$ Así se dio real provisión a 29 de noviembre de 1585 dirigida al corregidor, alcalde mayor y a los demás jueces de la ciudad de Córdoba «y a vos el escrivano de nuestra comisión dada al liçençiado Juan de la Vega sobre la cobrança del nuestro pecho y serbiçio de la moneda forera en los obispados de Córdoba y Jaén» y al escribano diligenciaro que se nombra por ella, llamado Alonso de Pedraça. Pues ante los alcaldes de los Hijosdalgo pareció el fiscal Amezaga y Alonso Álvarez de Villarreal, procurador en nombre de Córdoba, diciendo que se querellaban del licenciado Juan de la Vega y de los demás que parecieren culpados diciendo «que estando proybido por leyes de nuestros reynos que ningunos otros juezes pudiesen conoçer de las causas de hidalguías, sino los dichos nuestros alcaldes de los Hijosdalgo que residen en la dicha nuestra Corte, porque ellos pribativamente tienen el conoçimiento e determinaçión de los dichos negoçios, era ansy que bos el dicho juez, en quebrantamiento de las dichas leyes y en manifiesto desacato de los dichos alcaldes, so color del conoçimiento de causa de moneda forera e cobrança de ella abíades pronunçiado un gran número de veçinos de la dicha çibdad, que heran agora nuevamente pecheros, por hijosdalgo, eximiéndolos de la paga de la moneda forera, declarando no estar obligados a pagarla por ser hijosdalgo», ARChG, Registro del Sello, Caja 6438.

${ }_{34}$ Es evidente que a todos los hijosdalgo de Castilla no se les hizo pasar por el pleito de hidalguía y que muchos notorios hijosdalgo vivieron, ellos y sus descendientes, sin ser molestados por concejos y tribunales, y esto por las más variadas circunstancias que no tienen que estar siempre ligadas a la exclusión total de duda alguna sobre el origen de su nobleza. Ahora bien otros muchos sí, la notoriedad se rompía en cuanto el concejo los empadronaba o realizaba otra actividad, digamos, administrativa que pusiese en duda la nobleza hasta entonces inmaculada, era por tanto y hasta cierto punto, la notoriedad, frágil de ser reservada, pese al Derecho y a las normas que se están viendo que la protege. No sólo esto sino que los mismos titulares o sus descendientes, que gozaban de poseer una ejecutoria e incluso sobrecartas para que se cumplieran, eran molestados una y otra vez. Un ejemplo de esto lo tenemos en la real provisión, dada en Granada el 14 de enero de 1599, por la que se emplazaba al concejo de Buendía pues de él se había querellado, ante la Chancillería, Juan Coronado que decía ser hijodalgo notorio, hijo de otro Juan Coronado y de Ana López, y nieto de Francisco Coronado y Ana Hayuela, los padres y abuelos naturales y vecino de Garcinarro. Y que de ello, de su nobleza y notoriedad, tenía ejecutoria de hidalguía que ganó su abuelo en Granada litigada contra la localidad de Garcinarro, y que pese a haber presentado sobrecarta en Buendía, éstos lo tenían por pechero en la Moneda Forera y no acataban la sobrecarta regia, ARChG, Registro del Sello, Caja 6748. 
cambia, el concejo debe cumplir con las exenciones de los consignados en la ley, pero en realidad dejando una puerta abierta a que esto sea a su voluntad y mientras que le plazca ${ }^{35}$.

A cualesquier persona que se le entablare juicio debía hacérsele pechar, incluso si fuera lo que la doctrina llama hidalgo notorio, es decir el que no ha sufrido pleitos o menoscabos en su condición, pues dejaba inmediata y jurídicamente de serlo por ello, es decir perdía la notoriedad al ser pechado o prendado por ejemplo y que por esto se hubiese movido pleito o, antes de 1492, incluso simplemente con que se le negase su hidalguía ante el tribunal sin más condiciones y por tanto mientras pleiteara su hidalguía también habría de pechar, salvo que hiciera información ante el tribunal de que su padre y abuelo no pecharon por hidalgos en esa localidad, si había sido en otra tampoco le servía, sin olvidar que hacer esto era casi ganar el pleito pues es lo que había de hacer aquél a quien se le había interpelado en su nobleza. Los que exhibían sentencias pasadas en su favor o de sus mayores caían bajo lo mismo. Por tanto ahora soportaba directa y definitivamente la prueba de su notoriedad y de su nobleza en general el que se decía hidalgo, lo fuera o no, y no el concejo que simplemente con negar esta calidad con cualquier acto administrativo o jurisdiccional podía arrasar noblezas de siglos y, lo que es más, hacerlos pechar mientras que el pleito, si se entablaba, durase. Al hidalgo sólo le quedaba luchar en los tribunales del Rey y si ganaba o el concejo se apartaba, cuando las leyes se lo permitían a éste, poder exigir la devolución de prendas y pechos indebidamente sufridos y pagados como por otra parte era razonable cuando la Corona le reconocía como noble al que se le habían conculcado sus derechos. En definitiva un buen arma en poder de municipios que por las circunstancias que fuesen -razones más bien siempre alejadas del interés y conservación de la pureza de la nobleza- querían evitar que determinados grupos de personas estuviesen por hidalgos.

Durante todo el siglo XV y el XVI — sobre todo en su primera mitad- son continuas las solicitudes de reales provisiones realizadas por concejos a las Chancillerías y a los alcaldes de los Hijosdalgo para hacer pechar a los hidalgos mientras pleitean su nobleza o, ni siquiera con pleito por medio, para obligar a los que se decían hidalgos y que el concejo no los quería reconocer por tales a que pechasen, quedando como única alternativa a los nuevos pecheros a que fuesen ellos los que

35 Es sólo aparente, la práctica y la ley obligó a los hidalgos a probar sus exenciones obligatoriamente, posiblemente ello no pareciera siempre justo y produjo que algunos sostuviesen que la carga de la prueba, en esta cuestión de la pechería y del derecho a prendar al que se decía hidalgo debía de ser soportada - para evitar o bien abusos o bien componendas-desde un inicio y antes del juicio por el concejo y desde luego siempre durante el juicio, lo que nunca fue aceptado por la Corona, como ocurrió en la petición XLIX, del Ordenamiento de las Cortes de Madrid de 1534: «Otrosí, suplicamos a Vuestra Magestad sea servido de mandar que quando los concejos empadronaren a alguno por pechero, que sea obligado el tal concejo a haçer provança contra el tal enpadronado, so pena de perdimiento de los ofiçios, ansí en los pleitos pendientes y que pendieren, y de, cada, diez mil maravedís. A esto vos respondemos que mandamos que los alcaldes de los Hijosdalgo hagan justicia conforme a las leyes", Cortes de Castilla, Cortes de Madrid de 1534, Ordenamiento. 
recurrieran ante el Rey si se sentían en algo dañados. Ejemplo de esto último en que no hay pleito, lo tenemos entre otros en el siguiente ocurrido en la villa de Almendralejo por 1555, su concejo había aparecido ante los alcaldes de los Hijosdalgo y notario de la provincia de León:

Diziendo que en la dicha villa ay munchos vezinos que no son hijosdalgo ni tienen executorias de ello y por ser ricos y enparentados en el cabildo de esa dicha villa no los enpadronan ni reparten en los padrones y ansí dexan de pechar con los otros buenos onbres pecheros y ansí todos los pechos se reparten entre las biudas e pobres de esa dicha villa y nuestras rentas son menos çebadas, por ende que nos pedía e suplicaba le mandásemos dar nuestra carta e provisión para que vos el dicho conçejo hiziesedes enpadronar e enpadronásedes a todos los vezinos de esa dicha villa que no tuvieren sentençias e cartas executorias de sus hidalguías.

El Concejo iba a hacer pechar a muchos notorios hijosdalgo de solar conocido, a los que no quería reconocer su hidalguía, y que como notorios hijosdalgo -en el sentido tradicional de esta acepción- no poseían instrumentos con refrendo regio de su nobleza. El fiscal apoyó, como acostumbraba, la petición concejil, el resultado fue que se le mandó librar por el tribunal una real provisión, inserta la pragmática enriqueña, dada en Granada a 11 de enero de 1555 amparando las intenciones de la villa de Almendralejo y por tanto en virtud de todo dando pie, bajo amparo legal, a que se empadronase e hiciese pechar a todas aquellas personas que no poseían instrumentos como sentencias o ejecutorias que respaldaran su nobleza. En la misma provisión se dice a aquellos, a los que se sintiesen agraviados, que la única opción que tenían era recurrir a la Chancillería a demostrar sus derechos ${ }^{36}$.

En cuanto a la utilización de la pragmática de Enrique III para hacer pechar mientras transcurre el pleito al hidalgo las evidencias recorren toda la Edad Media, desde su promulgacción, y sobre todo durante la Edad Moderna hasta su fin, si bien cuando ante la Real Chancillería de Granada esto se hace más patente es durante el siglo XVI, dejando a un lado, claro está, la revitalización del uso de esta ley por Felipe V, ya en el XVIII.

${ }^{36}$ ARChG, Registro del Sello, Caja 5.736. Igual ocurre en Belinchón treinta años antes, pues se otorgaba una real provisión de emplazamiento dada por los alcaldes de los Hijosdalgo y notario del Reino de Toledo a favor del concejo de la villa de Belinchón, en 4 de octubre de 1520, en la que consta que ante los dichos jueces «paresçió la parte del Conçejo, alcaldes, regidores, ofiçiales e omes buenos de esa dicha villa e nos fizo relaçión por su petiçión que ante ellos presentó diziendo que ponía demanda ante los dichos nuestros alcaldes e notario a vos los dichos Luys Gonçales "e Álvaro de Ayllón e Juan de Canpos e (sic) de Orantes, Arias Pérez, su yerno, e Diego de Salzedo". E contando el caso dezía que seyendo vosotros pecheros llanos, fijos e nietos de pecheros e abiendo pechado con los omes buenos pecheros en todos los pechos e derramas de pecheros reales e conçejales que se abían hechado e repartido e hechavan e repartían en la dicha villa e en los otros lugares e partes e aviéndobos ayuntando en los ayuntamientos que avían fecho e fazían los omes buenos pecheros de los dichos lugares, de uno e çinco e diez e veynte e treynta e quarenta e çinquenta años a esta parte e de tanto tienpo acá que memoria de omes no es en contrario" sin embargo ahora decían que eran hidalgos y por eso se les ponía pleito. Negado el goce pacífico anterior de la hidalguía no sólo su origen, la Sala incorporó la enriqueña para que pechasen mientras durase el proceso, ARChG, Registro del Sello, Caja 5.531. 
Por mostrar algún caso, Albacete en 1539: había nuevos pleitos de hidalguía que seguía esta villa, el concejo albaceteño por medio de su procurador en Granada decía:

Conforme a las leyes e premáticas de estos nuestro reynos, pendiente el pleyto abían de ser enpadronados e repartidos e han de pechar e contribuyr llanamente con los otros pecheros llanos en los pechos reales e oficiales que la dicha villa repartiere. Por ende que nos pedía para que mejor se hiziese e cunpliese nos pedía e suplicaba mandásemos dar nuestra carta e probisión para que pendiente el dicho pleyto fuesen enpadronados.

Y tras esta petición sigue diciendo el documento:

E por los dichos nuestros alcaldes e notario visto lo susodicho fue acordado que devíamos mandar dar esta nuestra carta e provisyón ynserta en ella la pragmática del rey don Enrique ${ }^{37}$. 1539.

En definitiva se dio una real provisión a favor del concejo el 9 de julio de

Siguiendo con esta ejemplificación en 30 de abril de 1547 se daba una real provisión de emplazamiento por los alcaldes de los Hijosdalgo y notario del reino de Toledo dirigida al doctor Pedro Velázquez y Cristóbal Velázquez, hermanos y vecinos de Uclés, por ella se notificaba lo siguiente:

Paresçió Antonio de Talavera, procurador de cabsas en la nuestra Abdiençia, en nonbre del Conçejo, justiçia e regidores de esa dicha villa de Uclés, e presentó ante ellos una petiçión por la qual dixo que ponía demanda ante ellos contra vos los dichos dotor Pedro Velázquez e Christóval Velázquez, hermanos. E que así hera que siendo como vos los susodichos e cada uno de vos, soys pecheros llanos, hijos e nietos e deçendientes de tales, e como pecheros llanos vosotros e vuestro padre e abuelo e antepasados avíades pechado e contribuydo en la dicha villa y en las otras partes e lugares donde abéys vivido e morado, en los pechos e servizios de pecheros, reales e conçejales, y avíades estado en posesión de pecheros llanos de tienpo ynmemorial a esta parte. E agora vos los susodichos vos sustraéys de no querer pechar e contribuyr e no consentíades que el dicho Conçejo, sus partes, vos enpadronen e repartan los pechos de pecheros diziendo que soys hijosdalgo.

En resumen, el concejo de Uclés los había demandado ante la Chancillería. Pero ese mismo día, sin dar tiempo a que los Velázquez se pudieran empezar a defender, pues era el mismo 30 de abril de 1547, a petición del concejo y del fiscal de la Chancillería, se expedía otra provisión inserta la pragmática de Enrique III para que pechasen los Velázquez mientras durara el proceso ${ }^{38}$.

Una variedad, en cuanto al documento que la recoge, sobre esta forma de utilizar la ley enriqueña la tenemos el 2 de junio de 1567 cuando se otorgaba una real

\footnotetext{
37 ARChG, Hidalguía, Caja 5.093, pz.164.

38 ARChG, Registro del Sello, Caja 5.711.
} 
provisión de emplazamiento, esta vez contra el vecino de Úbeda e hidalgo notorio Francisco Galindo y, he aquí la variedad, en ella junto al emplazamiento estaba inserta la pragmática de Enrique III, a petición de la ciudad de Úbeda para que pechase durante el litigio el pretendido noble ${ }^{39}$.

Este tipo de real provisión en el que se mezcla emplazamiento y orden, a través de la enriqueña, de pechar mientras durase el pleito fue seguramente el más utilizado si bien no excluyó en el tiempo a que se practicasen ambas cosas por separado como demuestra el que ya iniciado pleito de hidalguía entre don Iñigo de Argüello Carvajal y el concejo de Las Brozas, este último y el fiscal López Madera consiguieran del presidente y oidores, estando el pleito en vista, que se expidiese una real provisión con la pragmática enriqueña dada en Granada a 26 de marzo de 1597 para que durante el resto del proceso pechase el notorio don Íñigo, al que en inicio y seguramente por negligencia, se le había reservado el honor de no ser pechado por su notoriedad ${ }^{40}$.

Casi todos, por no decir todos, los Trastámara contribuyeron con sus leyes y decisiones a la conformación de la normativa tocante al pleito de hidalguía, vayamos, evidenciando esto, a estudiar lo referente a Juan II y dejemos ya a Enrique III y a su exitosa pragmática enriqueña.

c) Juan II: intento de sometimiento de la independencia concejil

Estante en Medina del Campo, el 30 de agosto de 1436, el rey Juan II abordaba un problema que siempre se debió producir pero que se hacía más patente con seguridad cuando el pleito de hidalguía se insertaba como caso de Corte en los más altos tribunales regios. Había y hubo concejos muy beligerantes contra los hidalgos en general o contra algunos grupos de hidalgos en particular, todo lo cual solía estar motivado por enfrentamientos entre parcialidades incluso de nobles entre sí, pero también es cierto que en otros muchos casos los concejos no siempre respondían a este celo y que a veces eran muy permisivos con el tema -en esta vertiente a favor de la entrada de personas o grupos en el grupo jurídicamente noble.

La actitud de los concejos no sería realmente tenida muy en cuenta hasta que gracias a la progresiva configuración del proceso de hidalguía, cobran dentro de él una significación decisiva como motores de estas confrontaciones jurisdiccionales. De la actitud concejil dependía mucho la marcha del pleito y en ocasiones - por razones muy variadas - no estaban preocupados en empezarlos o en continuarlos y faltando una parte esencial, todo quedaba en nada. En tiempos de Juan II la situación y su problemática, era relevante, tanto que el Soberano decidió atemperar la notoria importancia del concejo en favor de la de la Corona y de sus órganos por

39 ARChG, Registro del Sello, Caja 6.049.

40 ARChG, Registro del Sello, Caja 6.708. 
lo que respecta a los pleitos en donde se dirimía la nobleza como asunto principal y no incidental.

La pragmática de Medina del Campo de 1436 entra a legislar este asunto. La ley en este caso está dirigida a los jueces y oficiales jurisdiccionales que conocen de este tipo de pleitos tanto en primera instancia como en otras etapas jurisdiccionales superiores, es decir a los alcaldes de los Hijosdalgo y notarios de reinos y provincias de la Corte y Chancillería y a los encargados de revisar sus sentencias en su caso, los oidores, pese a que los verdaderos afectados por ella sean sobre todo los concejos y sus actitudes. Así se establece por esta pragmática de 1436 (N.R. 2, 11, 11) lo siguiente:

1. En los pleitos ya comenzados en 1436 y los que en adelante se iniciaren sobre hidalguías, en los cuales o bien el concejo no se presente como parte desde su principio o bien, siendo parte, se desentienda de él, por los jueces a quien va dirigida la norma se deberá ordenar que los concejos junten a todos o a la mayor parte de los pecheros del lugar o a los diputados de ese Estado que estén previstos para tales circunstancias. $Y$ una vez reunidos manifiesten si tienen a la otra parte por hidalgo o por pechero.

2. Si el cabildo de pecheros da por pechera a la parte que se pretende hidalga, que siga el pleito el concejo, aunque no quiera, y sea obligado a ello por las justicias de la Chancillería y no se determine el pleito ni se den sentencias sin que esté y prosiga la parte del concejo.

3. Si el cabildo de pecheros da por hidalga a la otra parte y por ello declara no tener derecho a seguir el pleito, que lo sigan las justicias chancillerescas de oficio hasta que se sentencie y finiquite el mismo.

Es patente que cuando Juan II dispuso una norma específica para encauzar y corregir la actitud de los concejos, la problemática debía haber alcanzado cotas de importancia. Y analizando esta cuestión surgen en la norma tres aspectos dignos de resaltar.

El primero, resulta claro, es que los concejos habían descubierto formas, muchas de las cuales serían practicadas desde antaño, para estando este tipo de contencioso bajo la férula de la Corona seguir imponiendo sus intenciones por medio de artimañas que viciaban o inutilizaban los procesos. Intenciones muy diversas y que tanto estaban dirigidas a conseguir noblezas como a perder noblezas. Quede así planteado esto y su existencia.

El segundo aspecto a destacar es la importancia que debió tener inicialmente el parecer de los pecheros, del común de pecheros de cada población a la hora de reconocer a una persona por noble. En principio es algo meridianamente lógi$\mathrm{co}$, los perjudicados a nivel local por el reconocimiento de una nobleza, en puridad, no son los otros nobles, uno más, hablando asépticamente y sin entrar en 
consideraciones políticas, no importuna a los demás hidalgos en el goce de sus facultades y prerrogativas. Ahora bien, los que sin ningún resquicio de duda sufrirán el reconocimiento de una nobleza en una localidad, a este nivel, son los pecheros. Ellos deberán pechar y soportar servicios de todo tipo que corresponderían proporcionalmente a este vecino, nuevo o no, si en vez de reconocerle por hidalgo lo tuvieran por pechero. De esa forma considero que desde la etapa denominada de dispersión normativa debió ser sobresaliente la actitud de los pecheros a la hora de aceptar a una determinada persona, no excesivamente poderosa, como vecina noble o no de una localidad. El razonamiento del legislador es ése, si los pecheros, los afectados, están dispuestos a pechar lo que tendría que contribuir al que dan por noble, se puede suponer que el concejo hacía bien en no seguir el pleito o empezarlo. Por contra, si los pecheros no lo tenían por noble, el ayuntamiento estaba cejando en sus responsabilidades por los intereses que fuera al no querer atender al contencioso en pro del bien comunal ${ }^{41}$.

Lo cierto es que los concejos, en ocasiones y como actuación dilatoria dentro de la estrategia del pleito - no siempre para favorecer al hidalgo, como suele entender la historiografía -, no se daban por enterados del inicio del pleito y esperaban a ser declarados en rebeldía para entrar a él. La razón —en el caso de no existir componendas a favor del noble- era fatigar a la parte demandante, obligándola a solicitar la declaración de rebeldía, produciéndole gastos económicos y temporales, y aparentar, por otro lado, que entendían desde un inicio que la de-

41 La falta de pecheros en determinas localidades o zonas, y en virtud de legislación sobre pleitos de hidalguía como ésta de Juan II de 1436 y sobre todo con la pragmática de Córdoba de 1492 de los Reyes Católicos, provocó en más de una ocasión graves problemas a los hidalgos y dudas inclusive para las Chancillerías. Dudas que llegaron a alcanzar también y sobresalientemente a aquellos nobles provenientes de las cunas míticas de la nobleza española y castellana. Dicen las Cortes de Valladolid de 1555 en la petición CV «Otrosí, dezimos que muchos naturales de las Montañas y de otras partes destos reynos tratan pleytos en las Audiencias Reales de Valladolid y Granada sobre sus hidalguías. Y so color de la pregmática hecha por los Reyes Cathólicos en la ciudad de Córdova o de otras leyes destos reynos, los oydores y alcaldes de los Hijosdalgo de las dichas Audiencias ponen duda en pronunciar por hijosdalgo a naturales de las dichas Montañas y de otras partes, aunque prueban ser hijosdalgo de solar conocido. Dando a entender que tal probança se ha de hacer con testigos pecheros, e que los que litigan sobre sus hidalguías han de probar haber bivido o tenido bienes en lugares de pecheros, e haver estado en ellos en posesión de hijosdalgo: ellos, e sus padres e abuelos. La qual probança es imposible de haçer a muchos, aunque sean notorios hijosdalgo e de solar conosçido, por no haver bivido, ni tenido bienes, en lugares de pecheros. Y, pues es notorio, la nobleça antigua destos reynos tienen sus casas y solares conosçidos en cada parte, y es de creer que la intençión de los reyes que hicieron la dicha pregmática e leyes no fue obligar a los dichos hijosdalgo a provar cosa imposible ni quitarles su nobleza ni derecho, ni que lo proveydo para los hijosdalgo que viven en tierras de pecheros se estendiese a los vezinos de las dichas Montañas e de otras partes destos reynos, donde ay franqueza y libertad de no pechar porque sería indirectamente hazerlos pecheros. Suplicamos a V.M. por el remedio desto, como cosa tan importante al real serviçio e bien universal destos reynos, y conservaçión de la nobleça antigua dellos. E que mande declarar e se declare por tales hijosdalgo de solar conocido a los naturales de las dichas Montañas y de otras partes, que han bivido en lugares libres y essentos de pechos, aunque no lo prueven con testigos pecheros, ni ayan bivido ni tenido bienes ellos, ni sus padres ni abuelos en lugares de pecheros. De manera que quedaren por tales hijosdalgo de solar conoscido, ansí en posesión como en propiedad, sin los obligar a provar cosa imposible, ni que se les hagan sobre ello las dichas molestias y vexaciones». La respuesta como se acostumbraba en este tema no hizo novación: «A esto vos respondemos, que se guarden las leyes y pregmáticas de nuestros reynos», Cortes de Castilla, Cortes de Valladolid de 1555, Peticiones. 
manda era nula de pleno Derecho y que no debía ser amparada por el tribunal, ya que no había sido interpuesta por parte que pudiera querellarse al no ser hidalga esta última. Esto, a veces, era suficiente para que el hidalgo, al solicitar la rebeldía, exigiese que o bien el concejo contendiese o bien lo diese por hidalgo como establecía la ley de Juan II de 1436, pero esto también era exigido por el fiscal regio para poder continuar, en virtud de esta pragmática de Medina del Campo, el litigio contra los hidalgos con todas las garantías jurídicas.

De lo qual fue mandado dar traslado a la parte del dicho nuestro procurador fiscal, para que dixese y alegase de su derecho en el término de la ley. Por el qual, visto el proçeso del dicho pleyto, paresçió ante los dichos nuestros alcaldes y notario y presentó ante ellos una petiçión, en que dixo que por los dichos nuestros alcaldes y notario avía seydo dando mandamiento contra el conçejo e omes buenos de la dicha villa de Moclín, de pedimento de los hijos de Colmenares. El qual les fuera notificado e en el término en él contenido no paresçieran, que pidía a los dichos nuestros alcaldes y notario mandasen dar nuestra carta, ynserta en ella la premática del señor Rey don Juan, que aya Sancta Gloria, mandando al dicho conçejo declarase si tenían por hijosdalgo o por pecheros a los susodichos, conforme a la dicha permática. Porque vista la dicha declaraçión, él prosiguiese la dicha causa como hera obligado, lo qual se mandase a costa del dicho conçejo. E por los dichos nuestros alcaldes y notario, visto lo susodicho y cómo el dicho pleyto se hazía en ausençia y rebeldía del dicho conçejo, mandaron dar e dieron nuestra carta y provisión, ynserta en ella la dicha premática del dicho señor Rey don Juan, que aya Sancta Gloria, por la qual en efecto se les embió a mandar que declarasen si tenían por hidalgos o por pecheros a los dichos Diego de Colmenares e sus hermanos. Y si declarasen que los tenían por hidalgos, que lo hiziesen dar en pública forma en las espaldas de la dicha nuestra carta, e si declarasen que los tenían por pecheros, que enviasen su procurador sufiçiente, con su poder bastante, a seguir dicha causa ${ }^{42}$.

Resta un tercer y último aspecto a explicitar, y éste no es otro que la ley supone una medida más a favor de que las riendas del reconocimiento jurisdiccional de la nobleza queden bajo el Soberano. Los concejos siempre tuvieron y tendrán hasta la desaparición del proceso de hidalguía, reinando Isabel II en el siglo XIX, un papel esencial en todo lo que se refiere al reconocimiento y ejercicio de la nobleza, eso no desmiente que la evolución que aquí se está explicando hiciera que el reconocimiento nobiliario y algunos ejercicios derivados de la titularidad de la posesión o de la propiedad de hidalguía cayeran bajo la Corona de forma indiscutible, cuando menos desde el Derecho. Y aceptando estas dos situaciones que parecen contrapuestas y que en el fondo se complementan tanto a nivel legal como político y social, se ha de entender que la pragmática de Medina del Campo de 1436 del rey Juan II avanza en la solidez de la posición preeminente del Soberano con respecto a los pleitos de hidalguía en Castilla, desbancando aún más a los ayuntamientos. Hasta ese momento si la parte del concejo o no aparecía o se retiraba, en cuanto a la resolución del pleito todo dependía de, por un lado, que si

42 BN, Manuscritos, Mss. 11494. 
eran particulares los enfrentados, que quisieran o pudieran seguirlo hasta fenecerlo. $\mathrm{O}$, de otro lado, que siendo las partes enfrentadas el concejo y uno o varios particulares, y el concejo actuara de la forma antedicha, que o bien el que pregonaba y defendía su nobleza quedara por tal hidalgo o que ante la falta de la parte contraria quedara durante más tiempo o por siempre, al no poder finalizar el pleito, como pechero y sufriendo tal condición. En cualquier manera la causa de la justicia, de la que es valedor en la tierra el Rey por sí y a través de sus tribunales, quedaba diluida y al arbitrio de otros intereses, escapando de entre los egregios dedos para caer de nuevo en las manos concejiles o lo que es peor en las garras de bandos y personas que no buscaban la verdad y la justicia sino sus intereses.

Es cierto que sin la ley de Juan II había otra cuarta posibilidad, que no es otra que los alcaldes de los Hijosdalgo o los oidores por su motu proprio o por el del fiscal o incluso por el del Rey, siguieran la causa sin importarles otra cosa que la verdad, la justicia y cómo no, los derechos de la Corona, que también sufrían o podían sufrir realmente si eran muchos e importantes los que salían victoriosos y se eximían como hidalgos.

Esto tampoco parece que fuera habitual cuando el Rey tiene que ordenar a sus altos jueces que no se distraigan y que sigan el pleito con o sin el concejo. Y mejor con, pues se podía garantizar más el derecho del Común si participaba el ayuntamiento, pese a que lo hiciera con desgana, aunque sólo fuera porque todo tipo de costas que se hubieran de hacer para negar el derecho del noble, en su caso, si el hidalgo salía victorioso caerían bajo el deber de pago del concejo y no del Rey.

De ahí la importancia de esta norma de Juan II: mayor control regio en detrimento del concejil en los pleitos de hidalguía y obligación de los tribunales regios con competencia, de tener que terminar los pleitos en busca de la verdad, aunque sea la verdad judicial, pero a veces no hay otra y aunque la haya, a veces es, también, más decisiva la judicial que la verdad digamos real.

Y todas estas normas medievales de los Trastámara no sólo son significativas porque se utilizaran en su época o en épocas posteriores y por lo que ellas mismas, en sí, suponen tanto jurídica, como política y socialmente sino también porque son determinantes cuando se crea el verdadero pleito de hidalguía moderno por los Reyes Católicos.

\section{LOS REYES CATÓLICOS: DEL PLEITO DE HIDALGUÍA MEDIEVAL AL MODERNO}

El pleito moderno de hidalguía nace exactamente a la vez que la Modernidad española, pues la fecha de su creación coincide con el año emblemático de 1492.

Si bien es cierto que el año de 1492, en el XV, es el año en que para este proceso se establece un preclaro antes y después gracias a los Reyes Católicos, no 
es menos cierto que la solidificación de su estructura la verá el XVI. Y es que para proteger a los nobles, pero también para controlarlos bajo el manto regio, resulta necesario reconducir el proceso de hidalguía y aunque entre la ley de Juan I de 1379 (Era, 1417) y la pragmática de Córdoba de los Reyes Católicos de $1492^{43}$, existen leyes importantes, será esta última la que finalmente funde un proceso de hidalguía moderno y totalmente sometido a las Audiencias Regias ${ }^{44}$.

La pragmática de Córdoba de 1492, también las llamadas Ordenanzas de Medina y el comportamiento del Estado a través de los Reyes Católicos con respecto al reconocimiento y ejercicio de las facultades de la nobleza se hayan insertas en las corrientes que conformaron el Estado moderno, más que en las tradiciones medievales castellanas, si bien en ningún caso puede desvincularse a esta ley de Isabel y Fernando, de las de sus antecesores.

El fin de la Reconquista, pese a la posible aventura africana y a la que sería en su momento la indiana, junto con la configuración de otros vectores como el reforzamiento del poder regio, que si no se convierte en absoluto sí empieza a ser autoritario, o las nuevas economías y relaciones sociales, hacían palpable un cambio socio-político significativo, y desde luego muchos de los hombres a los que les tocó vivir aquellos años fueron conscientes de que empezaba una nueva era. Una nueva era que, como todas, partiendo de la anterior, supondría el fin de muchas cosas, de todas aquellas manifestaciones que no supieran evolucionar hacia nuevas tesituras y posiciones que la riada de cambios que ya llegaba traía consigo y que exigía de manera inequívoca la mutación o la extinción. No sólo había que cambiar por necesidad y espíritu de supervivencia sino también todos aquellos, que por las razones que fuesen, vieran mejoras en los cambios, ya fuere para ellos en particular o ya fuere para la sociedad en general, no sólo cambiaron sino que alentaron el mismo cambio, hasta cierto punto revolucionario.

Sabido es que los Reyes Católicos no aniquilan a la nobleza en sentido material - sería un disparate sólo pensarlo en aquellas épocas- la necesitan para sus fines, y la necesitan sana y fuerte, pero sí aniquilan para siempre a la nobleza en

43 NR 2, 11, 8.

44 La pragmática de los Reyes Católicos se vio pronto como fundamental para el pleito de hidalguía desde la doctrina, de ahí que casi todos los que escribieron de este tipo procesal se acercaron a ella con mayor o menor énfasis, pero entre sus comentaristas sobresalen dos buenos juristas del siglo XVI: Juan Arce de Otalora en su conocida Summa Nobilitatis Hispanicae et inmunitatis regiorum \& excusiatonem breuiter complectens... Salamanca, Andrea Portonaris, 1559 —estudiado él y su pensamiento por la Dra. Lorca Martínez de Villodres en LORCA MARTÍN DE VILLODRES, M. ${ }^{a}$ I.: El jurista Juan Arce de Otalora (s.XVI): pensamiento y obra. Madrid, Fundación Elías de Tejada y Erasmo Pércopo, 1997; y en, La nobleza en los comienzos del Estado Moderno. El pensamiento del Jurista Juan Arce de Otalora en la encrucijada del Medievo y la Modernidad. Madrid, Centro de Estudios Políticos y Constitucionales, 2004.; y más detenidamente fue ocupación de otro grande jurista, la ley de Córdoba de 1492, me refiero a Juan García de Saavedra, para mí más acertado que Arce en sus interpretaciones y por lo general más ajustado a Derecho y con una visión más pragmática, pero esto es eso, una opinión. Juan García de Saavedra, también conocido como Juan García-Gallego y que daría a la luz Tractatus de hispanorum nobilitate et exemptione siue ad pragmaticam cordubensem..., Valladolid, Juan del Bustillo, 1588, la que se siguió reimprimiendo hasta el siglo XVIII. 
cuanto a grupo que en sus más altas esferas ha querido ser, con una ambición extrema y a la vez lógica, el árbitro supremo del Estado por encima de su titular natural, en la ideología de la Recepción, el Monarca. Esas pretensiones que alentaron a muchos, desaparecerán para siempre con los Reyes Católicos - pese a la revancha nobiliaria castellana que vivió al fin de sus años Fernando el Católico-y habrá terminado, todavía más, habrá definitivamente fenecido tras las Comunidades, reinando el Emperador.

Los Reyes Católicos, por lo que respecta al reconocimiento jurisdiccional de la nobleza, se enfrentaron con varias cuestiones a resolver y con varias alternativas.

Obviando a los titulares de las grandes casas y a sus allegados, el resto de la nobleza en principio empieza a estar desencajada en la nueva estructura social y sobre todo política. Aspecto que debía ser solucionado. Una solución, claro está, que fuera útil al nuevo Estado. El fin del Medievo en Castilla es igualmente el fin de los grandes ejércitos señoriales a la antigua, también el de esas casas de nobles y magnates que no sólo poseen en su derredor otros nobles de menor rango económico que necesitan de ellos y se sirven de ellos, que viven en sus castillos y casas fuertes, etc., sino también es el fin del complejo entramado de relaciones feudo-vasalláticas entre las cabezas nobiliarias y sus satélites, a veces estantes en zonas geográficas lejanas a las verdaderas zonas de influencia política y territorial de los grandes señores. Madejas que se rompen y que en buen número desamparan a la mayor parte de la nobleza castellana.

El Estado necesita a la pequeña o mediana nobleza y sabe que la necesitará por tiempo, la alternativa de abandonarla a su suerte no es ni óptima ni realizable sin grandes discordias y sin que a la vez los grandes nobles piensen en recuperarlos. Mejor, siguiendo la idea de que el Monarca los necesita en sus planes de futuro, atraerlos pero a la vez dominarlos definitivamente y establecer regulaciones que por siempre, a la mayor parte de ellos, los sujete al Soberano.

Y qué mejor forma de conseguirlo por los Reyes Católicos a nivel jurídico, que hacer lo que habían pretendido sus mayores, es decir obtener por Derecho y por hechos que la nobleza se dé y se quite únicamente por el Rey y que el mismo Estado sea además el único que esté en competencia de decidir quién y quién no es noble.

Era la senda a seguir, pero no fácil en la práctica, habría que optar por la vía más idónea.

Una ley general que volviese etéreamente a decidir, ex novo, quién era noble o no, que explicitara sus facultades y obligaciones, en fin que viniera a representar una especie de código en que todo lo nobiliario fuera remodelado y concretado no era factible -impensable. Nobleza, ciudades y pueblos hubiéranse enzarzado entre sí y con la Corona en discusiones y enfrentamientos. Quizá hubiese quien lo pensara -mucho después Felipe IV y el conde-duque de Olivares se acercaron a 
estos planteamientos-, pero ése no era el instrumento más pragmático del que servirse.

Si el paso adelante en la Historia de Castilla, de España, que supone el reinado de los Reyes Católicos, para muchos de sus triunfos se había servido del pasado, ¿por qué no utilizar instrumentos medievales para, en los pleitos de hidalguía, llegar ahora a conseguir resultados modernos?

Además existían instrumentos medievales que aseguraban el derecho adquirido frente a terceros, no sólo basado en la potestad real absoluta, que posibilitaba a la Corona a intervenir en cuestiones nobiliarias tan importantes como era el decidir sobre la hidalguía de alguna persona, de forma exclusiva o casi.

Ésa era y fue la vía utilizada. Las leyes de sus pasados Trastámara estaban presentes y además habían sido llevadas a la práctica paulatinamente, con sus imperfecciones, pero se habían practicado, no eran nuevas ni a nobles ni a pecheros, eran tenidas como parte de la tradición legal española, se podían entonces utilizar para conseguir ese sometimiento último, al Estado, de los nobles. De ahí las leyes de Fernando e Isabel. Y de ellas sobresale la pragmática reseñada datada en Córdoba a 30 mayo de 1492.

Y para su estudio, se analizará primeramente la exposición de motivos. La ley se justifica en lo siguiente:

1. Se hace hincapié, como en otras leyes de Fernando e Isabel, en la falta de justicia que hubo en los reinos de Castilla durante el reinado de Enrique IV y durante las guerras civiles que dieron lugar a la entronización de Isabel como soberana castellana, tomando por fecha emblemática de partida el mes de septiembre de $1464^{45}$. Advertencia que se hace a los alcaldes de los Hijosdalgo y notarios de provincia, a quien por otra parte va dirigida la pragmática específicamente. Y sobre todo a este tipo de jueces que lo habían sido «desde mediado el mes de setiembre del año que pasó de mil y quatrocientos sesenta y quatro hasta agora".

2. Otórgase la ley a petición de los concejos que buscan protección y ayuda en el Soberano. Pero como es evidente se da para en último extremo asegurar los derechos de la Corona y en ellos, de forma principal, los hacendísticos: «en menoscabo y detrimento de los pechos y derechos a nos devidos y en agravio y daño de los dichos Concejos", dice la ley que ocurren las cosas. De manera que si lo denunciado por los concejos se mantuviese sin remedio «muy pocos quedarían pecheros en nuestros reynos y ansí no avría quién pudiese pagar los dichos nuestros pechos y contribuciones reales y oficiales, salvo honbres pobres y personas que no tuviesen quién tornase por ellos, lo qual dizque redundaría en grande cargo de nuestras

45 «No mirando que del dicho tiempo del año sesenta y quatro acá, huvo en estos nuestros reinos grandes escándalos y turbaciones y menguamiento de justicia», NR 2, 11, 8. 
conciencias y en desminución y detrimento de los pechos y derechos a nos devidos y en grande daño de los pecheros nuestros súbditos y naturales» ${ }^{46}$.

3. Entrando en lo que acaece, dice el preámbulo de la ley que los alcaldes de los Hijosdalgo y notarios, habiendo pleito entre alguien que se dice hidalgo de una parte y el concejo y el fiscal que se oponen a su nobleza, de la otra, los dichos jueces han sentenciado a muchos en posesión dejando el asunto de seguir la propiedad a fiscales y a concejos. De lo que a juicio de los municipios se produce grave perjuicio, pues siendo actores los hidalgos, normalmente, es a ellos a los que corresponde probar no sólo la posesión sino también y obligatoriamente la propiedad.

4. Dicen los concejos que para no seguir la propiedad, renunciando a conseguirla jurisdiccionalmente, en cualquier parte del pleito los hidalgos suspenden el petitorio, usando como basamento legal la ley de Juan I de 1384, pero interpretándola torticeramente.

5. Los concejos alegan que en esos tiempos es muy fácil probar la posesión a muchos, por las turbulencias pasadas desde 1464, pues «qualquiera que tenía en el lugar do vivía o en su comarca algún caballero, alcaide o persona poderosa a quien se allegaba y tenía caudal para litigar si quería llamarse hijodalgo, luego lo ponía por obra y el Concejo con quien avía de litigar y los oficiales de él y los empadronadores y cogedores de los pechos reales que intentavan de los empadronar y prendar, luego eran amenazados y amedrentados y aún heridos de ellos y deshonrados: de manera que el que se dezía hijosdalgo, no le osavan empadronar ni prendar (...) y como muy ligeramente podían y pueden provar esta posesión, aunque violenta y viciosa, con esta tal dizque an alcançado de aver las dichas sentencias» ${ }^{47}$.

6. Que estando la carga de seguir la propiedad en el fiscal y en los concejos, estos últimos no lo hacen pues «quedan gastados y fatigados de las costas y gastos que se han hecho en los pleitos que han seguido contra los tales que se dizen hijosdalgo y ven que por las sentencias que han dado, han pronunciado sobre la posesión de la hidalguía y que pendiente el pleito sobre la propiedad, aquella sentencia les ha de ser guardada, quedan tan cansados y fatigados de la prosecución del pleito que después no quieren bolver a intentar y proseguir la propiedad de él, aunque saben que tienen verdad y justicia en ello ${ }^{48}$.

7. Por último, a lo largo de la exposición de motivos de esta pragmática se abordan otros problemas que a juicio de los concejos suelen o solían su-

\footnotetext{
46 Idem.

47 Idem.

48 NR 2, 11, 8.
} 
ceder en este tipo de pleitos. Por ejemplo, se habla de la inclinación del alto tribunal a dar a la gente por hidalga por cobrar las doblas que le correspondían del hidalgo sentenciado favorablemente, entre otras prebendas que también los movían a prevaricar. Igualmente se alega que no se prueba bien conforme a Derecho la posesión y que incluso se dan sentencias a favor de bastardos o de hijos naturales pero no legitimados, o que las sentencias mal ganadas dan lugar a que hijos y nietos y todos los descendientes por varón del indebidamente agraciado queden por hidalgos en virtud de ellas, multiplicándose el fraude, etc.

La exposición de motivos, que resulta muy interesante, produce la visión de un estado catastrófico por lo que respecta a los pleitos de hidalguía y al tribunal que los ha de ver. Es una buena excusa para que el poder de los Reyes Católicos venga a poner orden, reforzando el Estado, el Estado moderno que se está fraguando, y en un tema tan significativo como la nobleza. Sin olvidar que además aparece el Soberano como dador de justicia, no caprichoso y arbitrario, quizá contra los hidalgos, sino para proteger al desvalido frente al poderoso, al concejo - la república de pecheros- frente al noble. Para traer la justicia a su reino.

Dada la significación que tiene la exposición, muy larga, de motivos, antes de penetrar en las regias soluciones se deben comentar algunos aspectos de ella, pero con precaución, pues no es inocente de ningún modo.

Uno de estos aspectos que evidencia la exposición de motivos de la pragmática de Córdoba es que la práctica de los hidalgos recurriendo a la Chancillería en vez de a otra jurisdicción para proteger el reconocimiento de su hidalguía ha seguido incrementándose a través del fin de la Edad Media, ganando fortaleza el pleito de hidalguía como caso de Corte. De este modo los concejos han perdido su preponderancia en el reconocimiento legal de la condición de noble y ellos mismos han de recurrir a la Corona en busca apremiante de soluciones, acusando a su gran enemigo jurisdiccional en esto, los alcaldes de los Hijosdalgo y notarios de provincia de ser los culpables de toda la situación.

Otra denuncia que surge en la exposición de esta ley, atañe al mismo origen de muchas noblezas, a un origen que se supone muy recurrente a lo largo del Medievo, no sólo al período más cruento del reinado de Enrique IV, y que se debe a la influencia de los usos feudovasalláticos. Olvidando milenarismos, la nobleza nunca fue inmutable en sus componentes. Las situaciones de concentración de poder a las que daba lugar el feudalismo en torno a un gran noble permitían que él mismo se convirtiera en fuente emanadora de nobleza para todos aquellos que le servían y que se encontraban en su derredor, aunque no fuera necesariamente en las cercanías más inmediatas. Por tanto las grandes cabezas nobiliarias medievales son, deliberadamente o no, fuente en la práctica de nobleza, incluso para la baja Edad Media, una fuente que basa su poder taumatúrgico que convierte a pecheros en nobles en la voluntad y el uso reiterado en la práctica. ¿Cuántos con el 
paso de los años medievales consiguieron o conseguirían el reconocimiento de su nobleza gracias a ser tenidos por tales y protegidos como tales por los señores a los que servían? Muchos, sin duda ${ }^{49}$.

Pero mientras que esta forma no afectó de manera reiterada y abundante a los municipios, sobre todo a nivel hacendístico, a estos últimos les resultaría totalmente indiferente, siendo por tanto sólo algo perseguible y a lo que oponerse por la Corona, pero ésta era en ese momento incapaz, por su debilidad, no sólo de perseguir tal práctica sino incluso de querer tener conocimiento oficial de su existencia.

La problemática se encona cuando la Corona, la Monarquía estaba inserta en un proceso imparable hacia su fortalecimiento y hacia el logro de su máxima ambición presentada como natural a ella por la teoría política, a gobernar y mandar en el reino sin sombras o con las menos posibles.

49 Ya he citado mi artículo sobre el poder feudal y la creación de la nobleza jurídica en la Baja Edad Media, en ese mismo artículo hago referencia a que en los pleitos de hidalguía se solía hacer hincapié en esta situación durante las probanzas. Y era cuestión que no sólo se hacía ver en la probanza sino por ambas partes, pero sobre todo por la opositora a la nobleza, en los escritos de demanda y contestación: «E por parte del dicho conçejo e omes buenos de la dicha villa de Requena fue respondido, entre otras cosas, en que dixeron que el dicho Hernando de la Cárçel era ome pechero e fijo e nieto de pecheros e por tales avidos él, e los dichos sus padre e agüelo, en los tienpos que viuieran e aviéndolos por tales los enpadronaran e prendaran en todos los pechos e tributos reales e conçejales que solían e acostunbrauan pechar todos los otros omes pecheros de los mis reynos e señoríos. E aviendo e teniéndolos por omes pecheros, en tal posesión estovieran e auían estado el dicho parte aduersa, e los dichos su padre e agüelo. E puesto que algunos se escusaran e ovieran escusado de pechar e pagar porque non tenían de qué pechar e pagar, o porque fueran pobres, o porque fueran allegados a algunos caualleros o escuderos o a otras personas poderosas que los escusaran de los dichos pechos e tributos contra razón e Derecho", ARChG, Pergaminos, n. ${ }^{\circ} 131$. Al fin, pese a lo arriba dicho, que por otra parte era casi formulario salvo que a la postre se demostrase veracidad, se le dio la razón y su nobleza a De la Cárcel por sentencia contenida en ejecutoria expedida en Valladolid el 16 de septiembre de 1459. Esta acusación y sospechas permanecieron en escritos de contestación a la demanda y en las probanzas de fiscales y concejos hasta el final de estos procesos en el siglo XIX, ya con un resabio goticista, pese a que la pregunta pudiese tener su traducción contemporánea en la actuación de un hombre poderoso para eximir como hidalgos a parientes y allegados, cosa que sucedía aunque no fuese ya rico hombre, caballero, escudero o alcaide, etc., el que maniobraba ilegítimamente. No obstante, no siempre era contraproducente estar emparentado o más aún servir a alguien de fuste, más durante el Medievo que durante la Modernidad por lo que se refiere a no levantar tantas sospechas en contra de la hidalguía sino todo lo contrario. Sobre el servicio me remito a mi artículo citado y para este trabajo en concreto al caso aquí citado de los Colmenares y su relación con la casa de Mendoza. Un ejemplo sobre parentesco es el siguiente, respectivo al linaje Lechuga de Baeza y Alcaudete: «En la dicha çiudad de Baeça, sábado, diez y nueue días del dicho mes de febrero e del dicho año del Señor de mil e quatroçientos y çinquenta y dos años (así comienza la probanza en la que se dice lo siguiente por un testigo)... E que sabe que el dicho Alfón Fernández es ome fijodalgo notorio de padre y de agüelo y de solar conoçido e que lo sabe, dixo, que de sesenta años a esta parte. Que este testigo se acuerda que el dicho Juan Alfón Lechuga, padre del dicho Alonso Fernández, e abuelo del dicho Juan Lechuga, en tanto que biuió y, y en esta dicha çiudad falleçiera, que sabe y vido que fue avido y tenido por ome fijodalgo notoriamente e que por tal lo viera sienpre acatar e que nunca jamás oyera dezir el contrario de ello. E, aún, que en aquel tienpo que oyera dezir públicamente por esta dicha çiudad cómo el dicho Juan Alfón era pariente muy çercano del arçediano que fue de Burgos, que no a memoria cómo se llamase, pero que sabe que era fijo de Lope Pérez, hermano de don Ruy López de Dávalos, condestable que fue de Castilla. E que lo cree ser así por quanto este testigo dixo que viera al dicho arçediano acatar al dicho Juan Alfón como a su pariente muy çercano», ARChG, Pergaminos, n. ${ }^{14}$. 
Y entre esas aspiraciones está la de convertirse en fuente única de mercedes, dones y noblezas e igualmente en ser la única capaz de reconocerlas desde el Derecho.

De ahí que el preámbulo de la ley gire casi íntegro alrededor de esto, explícitamente o no, según el párrafo.

Con la excusa de la súplica concejil, cierta pues se dio en reiteradas ocasiones, pero utilizada como evidente excusa, los Reyes Católicos deciden afrontar esta práctica un tanto fraudulenta desde el Derecho de hacerse nobles e inaceptable para un Estado fuerte, pero seguro que conocida por todos, y no sólo afrontarla sino hacer que finalice y que por lo menos se persiga por sus jueces y que en ningún caso sea aceptada como origen de hidalguía a proteger por medio de las sentencias de sus tribunales.

Igualmente una realidad, más política que jurídica al igual que las anteriores, y que es dada aquí de forma velada, es la persecución a toda la nueva nobleza surgida gracias a las mercedes de hidalguía que Enrique IV dio a sus seguidores reiteradamente y a veces casi en grupo (batalla de Simancas).

Los Reyes Católicos no podían aceptar bajo su gobierno a personas premiadas por ser parciales y fieles de su enemigo y hermano, sin obviar que las Cortes de Castilla apoyaban semejante actitud, solicitando la supresión de todas estas mercedes.

Pero esto se debe precisar, pues los mismos Reyes Católicos confirmaron bastantes y dieron nuevas, de manera que se entiende que lo que aquí se denuncia es que todas aquellas mercedes del desgraciado Enrique IV que habían sido anuladas siguieran produciendo consecuencias a favor de la hidalguía de sus titulares o de sus descendientes ${ }^{50}$.

Por último hay también en el preámbulo denuncias claramente jurídicas y que están dirigidas a la depuración del pleito de hidalguía y a la actividad de sus jueces -lo que no quiere decir que lo arriba expuesto y tildado de político o social no tu-

\footnotetext{
50 Antes, en 1487, ya habían promulgado en Salamanca una provisión sobre este tema y que al fin fue recopilada como NR 2, 11, 10. La excusa para ella fue que la ciudad de León se quejó de que muchos antes pecheros, se decían hidalgos en virtud de privilegios dados por el rey Enrique IV y se negaban ahora a contribuir. Según la exposición de la ley los medios que los partidarios del anterior monarca se habían hecho con la nobleza iban de los leales servicios hasta medios poco admisibles como la compra u otros más variopintos: «aviéndolos ganado con otros colores y maneras exquisitas». El problema es que muchos de ellos habían sido confirmados por los Reyes Católicos - un caso trabajado por mí sobre la familia granadina de los Moreno Maldonado, en ARChG, Hidalguía, 301-32-17. Por ello y tras consultas con el Consejo los monarcas dispusieron que los privilegios que habían sido dados entre 15 de septiembre de 1464 hasta el 5 de junio de 1465, pese a estar confirmados, serían nulos de pleno Derecho, al igual que los dados en adelante por Enrique IV, salvo que hubiesen realizado el servicio establecido como causa del privilegio y que además, de estos últimos, hubieran sido confirmados por servir también a Fernando e Isabel. No obstante se limitaba el goce de éstos, de diversas maneras, en los hijos del concesionario y sus sucesores. Por último se les tornarían marcos de plata que hubiesen pagado a aquéllos a los que revocaba el privilegio, aunque podrían tratarse de por vida de hidalgos para las honras pero no para eximirse de pechos.
} 
viera de la misma manera consecuencias jurídicas-, por ejemplo: se recuerda a los alcaldes de los Hijosdalgo la imposibilidad para el bastardo o para el natural no legitimado de recibir por herencia la hidalguía; también se llama la atención a que una sola sentencia no asegura la limpieza del resultado de todo el proceso; se expresa la benignidad de los jueces, decantados sin que necesariamente prevariquen, hacia el que se dice hidalgo; se denuncia el mal uso de la doctrina y requisitos de y para la posesión, por los jueces al dictaminar, etc.

En el fondo todo está encaminado a hacer manifiesta la necesidad de que se asegure aún más el proceso para que no existan fraudes excesivos que dañen según la excusa a los concejos, en realidad a la Corona, al Estado y a su patrimonio. Y para todo ello se dispuso lo siguiente:

1. Quien se dijera hidalgo y litigara sobre ello, según la instancia, ante los alcaldes de los Hijosdalgo y notario o ante los oidores y presidente de la Chancillería, ya fuera como demandante o como demandado, debería probar sobre sí, siendo casado o viviendo independientemente, y sobre su padre y abuelo la hidalguía que defiende, siguiendo para ello las reglas establecidas por las leyes de Castilla tanto para la propiedad como para la posesión, el procedimiento, etc., y si lo demostrase sería dado por hidalgo en posesión y en propiedad.

2. Quien estando litigando y defendiendo su posesión y propiedad, decidiera seguir sólo la posesión, debería suspender el petitorio de la propiedad en el tiempo y forma debido. En cuyo caso se seguiría exclusivamente la posesión.

3. Para demostrar ante el tribunal la posesión de la hidalguía se habría de asegurar que su padre y abuelo nunca pecharon y fueron exentos por su hidalguía. E igualmente habría de demostrar que durante veinte años continuos y cumplidos tanto el hidalgo que litiga, como su padre y abuelo, estuvieron en las localidades donde vivieron en quieta y pacífica posesión de hidalgos. Que por tal causa no los empadronaban y que se comportaban como nobles juntándose en los ayuntamientos de los hidalgos como uno más. Cumplido con todo esto sería declarado estar en posesión vel quasi de hidalgo y se podrá dictaminar por tal a través de una sola sentencia definitiva o por las demás que hubiere si el pleito fuere apelado y todo finare a favor del hidalgo. Recayendo la cualidad de pasada en cosa juzgada, se despacharía la correspondiente ejecutoria.

4. Cuando se juzgase sólo la posesión, quedaba al fiscal y al concejo contra el que se pleiteaba el derecho para seguir a su petición la causa de la propiedad.

5. Si el pleiteante que se autocalificaba de hidalgo, solamente probare de sí y de su padre la posesión de su hidalguía durante los veinte años referi- 
dos, y en ello no hubieran existido negligencias concejiles que fueron perseguidas por la pragmática de Enrique III (también por Juan I), sería sentenciado el hidalgo como titular de la posesión de su nobleza pero con eficacia territorial de su calidad, limitada solo al lugar y término donde viviera y contra el cual había sido pronunciado como hidalgo en posesión.

6. Mándase que desde la data de la ley, nadie pudiera ser dado por hidalgo, ya sea en posesión solamente o en posesión y propiedad, sino fuera siguiendo lo dispuesto por esta pragmática y que cualquier sentencia, privilegio o ejecutoria que se recibiera sobre ello no ateniéndose a esta norma, fuera nula de pleno de Derecho y por tanto ineficaz.

7. Se ordenó una revisión de todas las sentencias, cartas y privilegios dados desde 1464 hasta 1492 en favor de la posesión de hidalguías. Igualmente y por lo que se refiere a fechas, también se revisarían todas aquellas sentencias emanadas de los alcaldes de los Hijosdalgo y notarios, ya en posesión o ya en propiedad, que no hubieran sido suplicadas o suplicadas no se hubieran seguido las demás instancias, y sobre las que al fin recayó ejecutoria de las sentencias que había, sin que culminaran todas las etapas jurisdiccionales, es decir sin llegar a la suplicación sobre el asunto de fondo ante los oidores y sin que ellos fallaran en ello. Esta revisión quedaba sujeta a la petición de parte, petición de los que en virtud de todo este conjunto de disposiciones jurisdiccionales, ya fueran los titulares de las mismas o sus descendientes, se tuvieran por hidalgos y exentos. A ellos competía si deseaban ex lege seguir gozando de su calidad, el acudir a la Chancillería con los documentos que acreditaban su condición - sentencias, privilegios, etc.- con término para ello de cincuenta días y término que comenzaría a correr desde que en las cabezas de arzobispados, obispados y merindades se hiciera pública la pragmática.

8. Los comprendidos en el punto antecedente y presentados ante los oidores deberían contender con el fiscal de la Corte y el concejo donde fueren vecinos, sobre la propiedad, ante los alcaldes de los Hijosdalgo, o en instancias superiores sobre posesión y propiedad ante los oidores, ya fuera en apelación o en suplicación. También se decretó que se viera sobre el fondo de todo hasta culminar en suplicación el proceso, quedando por pechero el que lo perdiese y por hidalgo en posesión y propiedad el que lo ganare. $Y$ en el primer caso, que las doblas que llevaron en su momento los jueces fuesen devueltas al quedado por pechero o a sus descendientes.

9. Se estableció una excepción a la pragmática enriqueña en lo referente a quién debía o no debía pechar en el pleito. Ya que se limitó el efecto de las sentencias pasadas que tenían tal virtud inmunitaria durante el contencioso. Así serían efectivas para ello, hasta en un año de plazo, si el hidalgo que vienese a contender obtuviera un testimonio signado de escri- 
bano de la Audiencia y firmado de dos oidores y lo presentase ante su concejo, contando en él que en el término de cincuenta días había acudido ante la Chancillería en defensa de su derecho, lo que tendría que hacer, presentarlo a su concejo, en veinte días desde que lo obtuviera. Si lo hacía así no pecharía durante el pleito como máximo un año y si éste, el litigio, no se concluyese en ese plazo, a partir de que se cumplía el año seguiría ya pechando. Si en cualquier caso no hacía lo antecedente pecharía no obstante las sentencias o ejecutorias que tuviese durante todo el tiempo en que se realizare el proceso.

10. Si los concejos que hubieren sido requeridos por estos hidalgos no acudiesen a la Corte a contender sobre la propiedad de la nobleza del que se decía hidalgo, el procurador fiscal tendría potestad y obligación de contender sin que perjudicara el resultado del proceso la omisión concejil. Debiendo el concejo, pese a su inactividad, soportar los costos realizados por el fiscal, al cual se le daría carta cuando lo solicitase para obligar al concejo a pagar o en su caso para ejecutarlo.

11. Si en vista o revista, el concejo, emplazado por los oidores, dijese no querer contender sobre la propiedad contra el que ya tenía sentencia a su favor sobre sólo posesión o sobre posesión y propiedad dada por los alcaldes de los Hijosdalgo y notario, sería emplazado el dicho ayuntamiento por segunda vez por los oidores a nombre del que contendía y a su costa, para que el concejo acudiese a defender su derecho, estuviese el proceso en cualquier fase, pudiendo el municipio hacer todas las diligencias que estimara oportunas aunque términos ya dados hubiesen pasado. Independientemente de que el concejo acudiese o no a estos requerimientos, el procurador fiscal seguiría igualmente con la causa, e igualmente los oidores deliberarían sobre el fondo del contencioso ${ }^{51}$.

51 Por analogía, aunque aquí la ley se refería a las sentencias que se mandaron revisar por los Reyes Católicos, se siguió practicando el requerimiento a los concejos a nombre del hidalgo para todo tipo de pleitos de hidalguía, mucho después de la pragmática de 1492 como lo demuestra la siguiente real provisión del último cuarto del XVI: «Don Phelipe, etc., a vos los Conçejos, justiçias, regimientos de la çiudad de Andúxar e villa de Arjonilla y a cada uno de vos, salud y graçia. Bien savéys o devéys saber el pleyto que está pendiente en la nuestra Corte y Chançillería ante el nuestro presidente y oydores de la nuestra Audiençia que reside en la çiudad de Granada entre Françisco de Valençuela, veçino de esa dicha çiudad de Andúxar y su proqurador en su nonbre, de la una parte, y el liçençiado Diego de Amezaga, nuestro fiscal, y el Conzejo, justiçia y reximiento de la villa de Martos y su proqurador en su nonbre e vos los dichos Conzejo, justiçia y regimiento de esa çiudad de Andújar y villa de Arjonilla, que para este pleyto fuysteis çitados en vuestra rebeldía de la otra, sobre razón de la hidalguía que el susodicho pretende en el qual dicho pleyto, pareze que estando concluso ante los nuestros alcaldes de los Hijosdalgo, ante quien primeramente se comenzó el dicho pleyto, fueron por ellos pronunçiadas sentençias difinitibas en que declararon al dicho Françisco de Valençuela por onbre hijodalgo en posesión y propiedad. $Y$ en este estado por parte del dicho Françisco de Valençuela ante los dichos nuestro presidente y oydores fue presentada una petiçión por la qual dixo que en el dicho negoçio se avía pronunçiado sentencia en vista, que nos suplicava le mandásemos dar nuestra real provisión para la notificar a vos los dichos conzejos o que sobre ello le probeyésemos como la nuestra merçed fuese. Lo qual por los nuestros oydores bisto fue acordado que devíamos dar ésta nuestra carta para vos en la dicha razón. Y nos tubímoslo por 
12. Para conseguir la revisión de los hidalgos tenidos por tales en virtud de las sentencias que se querían revisar, a petición del fiscal los escribanos de los Hijosdalgo le proporcionarían a éste listas de aquéllos que habían conseguido sentencias favorables en las circunstancias arriba expresadas, desde 1464 hasta 1492.

13. Para evitar componendas entre hidalgos y concejos o abusos de los hidalgos notorios que deseaban obtener el refrendo regio de su nobleza sin que su inmunidad fiscal hubiese sido nunca avasallada, con el único objetivo de tener un documento legal que afirmara la conservación de su nobleza, con lo cual —en el primer caso- no sólo se iba abiertamente contra la justicia y lo justo sino que además -en ambos- se hacían gastar sin motivo los propios de los concejos o los caudales de los pecheros por medio de repartimientos para sufragar los pleitos, se ordenó que no se admitieran en la Corte causas de hidalguía contra concejo, fuera en posesión o en posesión y propiedad, sin que previamente hubiese habido prendas por medio. Lo cual se haría constar en la carta de emplazamiento ${ }^{52}$.

bien, por la qual bos hazemos saber el estado del dicho pleyto y vos mandamos que del día que vos fuere leyda e notificada, estando juntos en vuestros cabildos y ayuntamientos si pudiéredes ser avidos y si no diçiéndolo o haçiéndolo saber a un alcalde con dos regidores y al proqurador de ese dicho conzejo para que vos lo digan y hagan saber y de ello no pretendáys ynorançia, diçiendo que no lo supistes ni bino a vuestra notiçia, hasta diez días primeros siguientes hasta ser cunplidos y dentro de ellos y si quisiéredes enbiéys a la dicha nuestra Audiençia ante los dichos nuestro presidente y oydores vuestro proqurador sufiçiente con vuestro poder espezial y bastante en seguimiento del dicho pleyto y causa contra el dicho Françisco de Valençuela y a tomar traslado del dicho pleyto y a estar y ser presente a todos los autos de él hasta la sentençia difinitiva ynqlusibe y tasaçión de costas si las ubiere. Para lo qual todo lo que dicho es y para todos los demás autos a que de Derecho deváys ser çitados, vos çitamos, llamamos y enplazamos perentoriamente con aperçibimiento que vos hazemos que si dentro del dicho término enbiárades el dicho vuestro proqurador con el dicho vuestro poder, sigún dicho es, los dichos nuestros oydores vos oyrán y guardarán vuestro Derecho, en otra manera, en vuestra ausençia y rebeldía, oyrán a la parte del dicho Françisco de Valençuela en todo lo que dezir y alegar quisiere sin vos más çitar y llamar. Y sobre ello y sobre todo harán y determinarán en el dicho negoçio lo que hallaren por Derecho. Y los unos ni los otros no fagades ende al so pena de la nuestra merçed y de diez mil maravedís para la nuestra Cámara y fisco. So la qual dicha pena mandamos a qualquier escribano público que para esto fuere llamado que vos la notifique y dé testimonio sinado de cómo se qunple nuestro mandado. Dada en Granada a quinze días del mes de febrero de mil y quinientos y ochenta y tres años. Los señores licençiados Villares, Luys Laso de Çepeda, Laguna», ARChG, Registro del Sello, Caja 6.372.

52 La trascendencia de la imposición de una única causa metajurídica para dar lugar al pleito de hidalguía es sobresaliente y a veces el tener que hacer constancia de haber sido prendado para poder recurrir al amparo de la Sala de los Hijosdalgo se convirtió en calvario, sobre todo cuando el concejo prendaba o hacía pechar pero no lo anotaba, no había prueba del avasallamiento del derecho del noble. Ocurrió si no mucho en más de una ocasión, unas veces por picardía concejil y otras por negligencia a la hora de hacer o conservar padrones de repartimientos. Que era algo importante esto y que podía imposibilitar la defensa del hidalgo se mantiene en la común opinión y en la práctica durante la Edad Moderna: en Cazalla de la Sierra entrado el siglo XVII, había un hidalgo avasallado en su inmunidad fiscal pues «Juan Garçía de Llamas, procurador en ella (en la Chancillería de Granada), en nombre de don Diego de Pereda y Belasco, vezino de la dicha villa de Cazalla de la Sierra, juridizión de la ziudad de SeviIla, por una petiçión que presentó se querellavan ante nos de los repartidores nonbrados por el conzejo de esa dicha villa para repartir entre los vezinos de ella el pecho del Serbizio Real, que era pecho de pecheros. Diziendo que siendo el dicho su parte, sí es, onbre yjodalgo de sangre notorio, de sí y de su padre y abuelo y demás açendientes por línea reta de varón de tienpo ynmemorial a esta parte», hasta aquí nada anormal pues parece una real provisión de emplazamiento, pero no lo era sino una real provisión 
14. Los alcaldes de los Hijosdalgo y los notarios quedaban inhibidos del conocimiento de todas estas causas susodichas a revisar — no se puede ser juez y casi parte, pues se estaba viendo también su actuación o la de sus colegas-, recayendo en los oidores todas las competencias sobre estos asuntos. Oidores que deberían por medio de los escribanos hacer insertar la pragmática de Córdoba cuando emplazaren a los concejos sobre la cuestión de la revisión de las hidalguías de 1464 en adelante.

15. Por lo que se refiere a la innovación en determinados métodos de prueba o que afectan a ellos, se admitió que sin prenda por medio, sino por causas como la ancianidad de testigos — que corrían por ello peligro de muerte- o porque testigos de importancia por lo que se refiere a este asunto fueran a mudarse a otros lugares, se facultaba, digo, al hidalgo a que realizare, según Derecho y sin necesidad de que existiese pleito, información de sus dichos ad perpetuam rei memoriam ${ }^{53}$.

16. En consonancia con el tema probatorio tratado en el punto de arriba, tanto para la posesión como para la propiedad, cuando el abuelo sobre el que el litigante intentaba esclarecer su nobleza, hubiese sido tan antiguo que nadie quedase que lo llegara a conocer personalmente, se admitiría como prueba suficiente acerca de él lo que depusieran los testigos a través de la fama o de los comentarios que llegaron a conocer del susodicho abuelo. Pero la posesión pacífica de la hidalguía de 20 años debería ser demostrada por el hidalgo, de sí y de su padre.

La norma de 1492, como mayoritariamente lo son sus contemporáneas, es casuística en bastantes aspectos de ella más que general. En principio pareciera que venía sólo a solucionar puntos concretos que una vez resueltos acabarían con la vigencia de la misma ley o por lo menos con su utilidad, pero no es ni fue así.

previa en donde el hidalgo avasallado al que le habían repartido cinco reales exigía que el concejo o se los devolviese o lo pusiese por escrito en los padrones de pecheros que así había sido, para en consecuencia recurrir el amparo de los alcaldes de los Hijosdalgo, cosa que no podía por el momento hacer por no existir más evidencia que su palabra. Ganó la real provisión en ese sentido a 16 de noviembre de 1638, ARChG, Registro del Sello, Caja 7.453.

${ }_{53}$ La probanza ad perpetuam era arma de doble filo. En la frontera del siglo XV al XVI y sobre todo ante la pragmática cordobesa y su paulatino cumplimento por ambas Chancillerías, así como por la actuación de los concejos que demandaban en masa a los que se decían hidalgos, era necesario a muchos el conseguir esas probanzas como precaución. Y es que sabían que morirían testigos y se perderían memorias y quedarían sin poder probar abuelos e incluso padres, pues aún no había un conjunto documental escrito que pudiese evitar el recurrir a testigos en exclusiva. Lo que comenzaba como simple probanza sin contencioso por medio podía dar lugar, mientras se permitió, a denuncias de particulares, y siempre a la oposición del concejo e incluso sin todo esto, a la intervención del fiscal que estaba obligado a revisar la probanza y casi, también, obligado jurídica, moral y políticamente a ponerla en entredicho y a no permitir se creara un instrumento que salvara noblezas que librarían del fisco a muchos. Ocurre, entre a otros, lo último, a los Díaz-Hidalgo de Villarrubia de los Ojos en el siglo XVI, Vid. DíAZ DE LA GUARDIA Y LÓPEZ, L.: «Linajes nobles de Villarrubia de los Ojos en el siglo XVI y la Real Chancillería de Granada», Cuadernos de Investigación Genealógica, n. ${ }^{\circ} 12$, (1999), págs. 143-164. 
El problema de la nobleza, no creada conforme más que a Derecho, conforme a justicia, estaba ahí y era la excusa. Excusa para someter la posición del concejo a la Corona de forma concluyente en estos contenciosos. Y este sometimiento ya no sólo servirá para el problema de esos dudosos hidalgos sentenciados entre 1464 y 1492, sino para siempre.

La actividad concejil sigue siendo importante y lo será hasta el final, pero el Estado acapara o lo intenta, mucho del protagonismo municipal, perseverando en lo dispuesto por Juan II, al otorgar plenos poderes a los fiscales y a la vez al obligarlos a llevar el proceso hasta las últimas consecuencias, con o sin concejos.

De igual forma se limita a su vez la capacidad de los alcaldes de los Hijosdalgo y notario. Antes podían ser primera y única instancia, sin que estuvieran incumpliendo ningún mandato. Ya no, estando obligado el fiscal a proseguir, deberá apelar por el pro comunal y por el estatal.

De ser en ocasiones, bastantes, los alcaldes y notario los únicos jueces que habían intervenido para declarar a una persona noble o pechera, sus pronunciamientos habrían ya en el futuro de pasar dos confirmaciones, vista o revista, y ya no serían ellos sino los oidores los que tuviesen definitivamente la última decisión. $Y$ esto que en principio surgió de la necesidad de revisar las sentencias pasadas, será tenido como de obligado cumplimiento hasta el fin de la Edad Moderna para que cualquier contencioso de hidalguía quede perfectamente resuelto.

Lo anterior produce un encarecimiento de todo el proceso, encarecimiento que sufren ambas partes, pero que hace que todos aquellos que fueran pobres y se dijeran hijosdalgo tuvieran cercano el momento de ser tenidos jurídicamente por tales, eliminando así bastantes, al no poder afrontar los costos hasta el fin ${ }^{54}$.

En este epígrafe ha sido deliberadamente relegado a su final un aspecto sobresaliente de la pragmática de Córdoba de 1492. Y ha sido relegado al fin precisamente para recalcar la importancia fundamental del mismo.

La naturaleza hacendística del pleito de hidalguía ha sido destacada comúnmente tanto por los historiadores como por los genealogistas, etc, en definitiva, por cualquiera que se haya acercado a él. Pero esto es cierto y no es cierto.

El pleito de hidalguía nunca fue considerado como un pleito de naturaleza hacendística o fiscal, su naturaleza fue siempre tenida como civil por parte de la doctrina del Sistema Jurídico de la Recepción del Derecho Común, ni siquiera mixta

54 Muchas son las quejas que de esto se conservan tanto en la documentación de las Chancillerías para casos particulares como a nivel superior, por ejemplo en las Cortes del siglo XVI. Así consta el la Petición CXV de las Cortes de Segovia de 1532: «Muchas personas que son hijosdalgo en estos vuestros reynos son fatigados y molestados por los conçejos donde biven, prendándolos en los pechos reales y conçegiles, como sy fuesen pecheros, los quales por ser pobres no pueden seguir la causa por las muchas costas que se les recresçen y quedan por pecheros ellos y sus desçendientes, y algunos que lo pueden seguir, quando a cabo de mucho tienpo han sentençia en su favor quedan perdidos, destruydos y gastados, y sobre ello Vuestra Magestad deve proveer por manera que estos no reçiban agravio...", Cortes de Castilla, Cortes de Segovia de 1535, Cuaderno de Peticiones. 
sino civil, pese a que aquí se haya apuntado que rozaba esta naturaleza mixta desde la disposición de 1384 de Juan I.

Ciertamente, ateniéndose a parámetros estrictamente jurídicos siempre tuvo esa naturaleza civil, tanto de forma como de fondo: en cuanto a lo primero, el pleito de hidalguía, como la inmensa mayoría de los procedimientos jurisdiccionales, tenía como cauce el procedimiento civil, lo que siendo tan común quizá no permita discernir naturalezas con exactitud.

Aspecto distinto es la cuestión de fondo del pleito de hidalguía —res de qua agitur, así se abría este análisis de los pleitos de hidalguía-, y la cuestión de fondo en este tipo de procesos es netamente civil. En ellos se discutía y se juzgaba la titularidad de la posesión o de la propiedad de algo incorporal, la nobleza, y el goce que se decantaba de esa titularidad y de las facultades que lo constituían como tal derecho ${ }^{55}$.

Entonces ¿dónde radica esta naturaleza hacendística, si no jurídica sí de hecho, en el pleito de hidalguía? La respuesta es relativamente simple: en la causa metajurídica que permitía el amparo jurisdiccional como tal pleito de hidalguía.

Hasta la fecha de 1492 se había ido canalizando y estructurando el pleito de hidalguía de forma cada vez más nítida, como se vio Juan I fue el gran impulsor, pero la causa por la cual se podía contender ante el Rey, la causa metajurídica del proceso no estaba bien delimitada. Aunque es muy posible que pronto la causa más usual que daba comienzo a estos litigios fuere desde antiguo la hacendística:

Don Johan, por la gracia de Dios, rey de Castillla, de León,... al conçejo e alcaldes, e alguasiles e otras justiçias e ofiçiales qualesquier, de las Casas de Reyna, lugar de la encomyenda de Reyna e del maestradgo de Santiago e a todos los conçejos, corregidores e alcaldes e otras justiçias e ofiçiales qualesquier de todas las çibdadaes e villas e lugares de los mis regnos e señoríos, que agora son e serán de aquí adelante e a qualquier e qualesquier que cogen e recabdan o ayan de coger e recaubdar e enpadronar y en el dicho lugar de las Casas de la Reyna o del dicho maestradgo de Santiago, e de todas las çibdades e villas e lugares de los mis regnos e señoríos en renta o en fialdat o en otra manera qualquier... Sepades que pleyto en la mi corte ante Johan Arias, ballicher en leyes, e Garçía Sanches de Olmedo, liçençiado en Decretos, mis alcaldes de los Fijosdalgo, e ante el dotor Ruy Garçía de Villalpando, mi notario del regno de León. El qual dicho pleyto era entre Alfon Sanches Fresnedo e Johan Alfón, e Diego Alfón, sus hermanos, vesinos del

\footnotetext{
55 Una simple aclaración que es posible que sobre, pero que he escuchado e incluso visto escrita. Se trata de la «coletilla» vel cuasi, que alguno ha interpretado como que, al haber soportado el noble un pleito sobre su condición, se está dejando en duda por el tribunal y según Derecho, durante todo el proceso e incluso en las sentencias, la verdadera nobleza del litigante que ganase el pleito, precisamente por ello, por haberlo sufrido. O también, en mejor caso, no que se pusiese en duda la nobleza sino que se había roto definitivamente su notoriedad y la de su linaje. Lo cual es contradictorio cuando las sentencias de todas las épocas los reconocían como nobles notorios de solar conocido. Y es que vel cuasi como es sabido por los juristas, de ahí casi lo innecesario de esta aclaración, nada tiene que ver con lo antedicho sino con la condición incorporal de la nobleza entendida como cosa — res-y el tratamiento que el Derecho Romano y Común dio a este tipo de posesión y propiedad sobre cosas no aprehensibles.
} 
dicho lugar de las Casas de Reyna e sus procuradores en su nonbre defendientes de la otra parte. Sobre rasón de la demanda que por el dicho alfón Sanches, por sí e en nonbre de los dichos sus hermanos, fue puesta contra el dicho mi procurador fiscal e contra el procurador del dicho conçejo, En que dixo que él e los dichos sus hermanos siendo omes fijosdalgo de padre e de ahuelo e de vengar quinientos sueldos según fuero de Castilla e los dichos su ahuelo e padre e los dichos sus hermanos e él aviendo estado e estando cada vno en su tienpo en posesión vel quasi de omes fijosdalgo... de non pechar nin pagar en pechos algunos reales nin conçeiales, saluo en los pechos que pagaran e pagauan los otros omes fijosdalgo de los mis regnos... e que uosotros el dicho conçejo e alcaldes e omes buenos del dicho lugar de las Casas de Reyna e otros por su mandado e en su nonbre, ellos auiéndolo por rato e por firme, de tres meses a esa parte, poco más o menos tienpo, que los enpadronauan e fisieran enpadronar con los pecheros del dicho lugar en los padrones e derramas que fieran e repartieran entre sí del pedido e monedas que yo e el infante don Emrique, mi primo, maestre de Santiago, nos quisiéramos seruir. E que los prendaran e fisieron prendar prendas: alfamares e una aljuba de paño de la tierra toquesado, en que podía auer quatro varas, e un almadraque nuevo de cama e vna açada e un açadón de fierro e otras prendas que podían valer mil e quinientos maravedís por les quebrantar las dichas sus fidalguías e yr contra ellas e les pertubar en la dicha su posesión vel quasi de las dichas sus fidalguías en que así avían estado e estauan por lo qual los sobredichos eran tenudos a les guardar las dichas sus fidalguías e a les non perturbar en la dicha posesión vel quasi en que auían estado e estauan e e a les guardar las honras e franquesas e libertades que auían e deuían ser guardadas a los otros omes fijosdalgo de los mis regnos e señoríos e a les tornar las dichas prendas... ${ }^{56}$.

Pero lo cierto, según Derecho, es que en realidad hasta 1492 con la simple negación de la calidad, dos particulares podían contender y la cuestión de fondo sería la titularidad de la nobleza, la ley del Fuero Viejo arriba transcrita lo atestigua, y de hecho aún durante la Modernidad se encuentran ejemplos, fallidos, pero ejemplos en los que hidalgos solicitan el amparo de los alcaldes de los Hijosdalgo ante cualquier asunto relativo a su nobleza, sin embargo o bien recibieron la denegación del amparo como respuesta de la Sala de Alcaldes de los Hijosdalgo o bien éstos se declararon no competentes y estas peticiones, de ser vistas, pasaban a la competencia de los oidores, pero nunca como pleitos de hidalguía, pues ni se consideraban tales ni se pueden considerar ahora como pleitos de hidalguía, sino como actos procesales en los que la hidalguía no es cuestión de fondo sino incidental: honra, crímenes, deudas, etc., serían la cuestión de fondo, la hidalguía dentro de estos procesos sólo una incidencia ${ }^{57}$.

56 Se trata del inicio de una ejecutoria de 1426 citada anteriormente aquí, ARChG, Pergaminos, n. ${ }^{\circ} 44$.

57 Un caso significativo lo encontramos, de hecho, en los pleitos de mitad de oficios, tan ligados a la nobleza, que no se vieron nunca por las Salas de Hijosdalgo, no he encontrado ninguno de fines del XV y desde luego para la Edad Moderna no hay duda que no entendieron de estas contiendas en la Chancillería de Granada. Igualmente, cuando en tiempos de Felipe Il los cuantiosos que se decían hidalgos se negaron profusamente a ser tenidos por tales y a servir así a la Corona, ésta remitió en comisión a la Sala de los Hijosdalgo de Granada, pero en comisión, pues aunque hubiesen sido verdaderos hidalgos y algunos incluso tenían ejecutorias y era evidente, no era Sala competente para ver pleitos en que el fondo no era si eran hidalgos o no, sino si habían de ser cuantiosos o no, y la nobleza se estaba utilizando incidentalmente como cuando alguien se decía hidalgo, para no ser encarcelado por deudas. 
Que la causa metajurídica por la que se podía contender ante los alcaldes de los Hijosdalgo y notario sobre la posesión o propiedad de la hidalguía no estuviera delimitada, producía o podía producir desde contubernios poco dignos hasta que los altos tribunales, que en principio debían entender de graves causas, estuvieran casi colapsados y en este caso los alcaldes de los Hijosdalgo ante invasiones e invasiones de demandas sobre nobleza, no realmente justificables para que las conocieran las más altas instancias jurisdiccionales en exclusiva. Había que delimitar la causa metajurídica que pudiera desencadenar un pleito de hidalguía en el que se viera si una persona era noble o no y como tal si era protegible por el tribunal para que no se destruyesen sus derechos y facultades.

Y precisamente fue el tema hacendístico el que se utilizó desde la pragmática de 1492 como única causa metajurídica que podía dar lugar a un pleito pleno de hidalguía y esto fue lo que terminó configurando ese halo económico al pleito de hidalguía, que a veces induce a error a los que se acercan a analizarlo en la actualidad.

Para el Estado cualquier materia que pudiera perjudicar o cuando menos atañer a sus posibles ingresos, siempre necesarios, suponía una materia esencial. Es obvio.

El privilegio de exención contributiva estaba en contra de cualquier Estado y más de uno Moderno que necesitó y necesitaba imperiosamente de recursos económicos con los que afrontar sus políticas y la burocracia que las sustentaba. A los concejos, pilar importante de la Monarquía, también les afectaba en demasía, pero al Estado, a esa Monarquía le interesaba obtener los ingresos fuera como fuere, evitando en lo posible demasiados sufrimientos que pudieran volverse en su contra, pero, superando esto, quedaba al final la necesidad de obtener ingresos al precio que fuese.

De ahí que debiera vigilar pertinazmente, cuando menos en teoría, quién se eximía de contribuir con su dinero en virtud de cualquier calidad, aquí la nobleza.

Durante el Medievo, dentro de límites que no corrompieran las esencias de las estructuras sociales, para magnates laicos o eclesiásticos y para la Corona resultaba inocuo que un sujeto o un grupo de sujetos se autodenominaran nobles y se sintieran tales. Incluso, dentro de ciertas limitaciones reitero, podía resultar positivo al sistema en su conjunto al transmitir a mayor número de personas, por medio de estos ideales nobiliarios, determinadas pautas de comportamiento y sentimientos favorables y afectos al mantenimiento de la estructura social vigente y de sus fines. En realidad, la mayor parte de los usos y derechos derivados de la condición nobiliaria - todavía por descubrir, describir y analizar - afectaban limitadamente a su entorno y menos aún al poder, sólo algunos muy concretos transcendían y podían llegar a ser profundamente dañinos a determinadas estructuras si conseguían ganar un protagonismo inusitado, ya sea cuantitativa o cualitativamente. 
De todos ellos los relativos a las inmunidades de los hijosdalgo cobraron pronto fuerza como las más incómodas no sólo a la Corona sino a concejos e incluso, quizá, a la cúspide nobiliaria titular de señoríos.

Que alguien fuera en una comitiva delante de otro o no, importaba e importaba en conjunto, es decir no particularmente y en un caso concreto, para el mantenimiento de una serie de valores que amparaba el Poder político y que a su vez protegían al mismo, pero para eso podía cualquier tribunal intervenir.

Ahora bien, incluso en un sólo caso concreto, por lo que respecta a la inmunidad fiscal, sí se estaba dañando el interés público a través del resentimiento de las arcas estatales e incluso si el sujeto era muy rico, esto podía ser de manera verdaderamente gravosa. Por lo tanto sí se debía afrontar el coste político, económico y jurisdiccional empleado en ese control, aspecto diferente es que lo intentado surtiera el efecto deseado, pues como en casi todos los sistemas jurisdiccionales el rico tenía más posibilidad de vencer en el contencioso que el pobre, que a veces ni podía comenzarlo, por lo que quedaban más hidalgos pobres entre los pecheros mientras eran los ricos - verdaderos nobles en origen o no- los que solían salir victoriosos con mayor frecuencia. Si bien sí es cierto que había una mayor masa de contribuyentes aunque fueran pobres o medianos al perderse ciertas noblezas y sus correspondientes inmunidades.

Por ello en su pragmática de 1492 los Reyes Católicos disponen:

Y otrosí, porque no es fecha relación que muchos que se dizen estar en posesión de hijosdalgo y no son prendados por los Concejos donde viven, ganan de los dichos nuestros alcaldes de los Hijosdalgo y notario de la Provincia, nuestras cartas de emplaçamiento contra los Concejos donde viven, y les hazen gastar sus dineros en seguimiento de los emplaçamientos, reçelándose que los harán pechar y hazen sus conciertos con los que goviernan los Concejos, para que no se siga el emplaçamiento y así han más ligeramente las sentencias de sus hidalguías. Por ende mandamos, que de aquí adelante los dichos alcaldes no den, ni libren cartas de emplaçamiento, ni escrivano alguno se las dé a librar contra ningún Conçejo sobre causa de hidalguía, sobre posesión ni propiedad, salvo si se le huviere ya prendado el Concejo por pechero al que se dize hijodalgo, y que ansí lo declaren en las cartas de enplaçamiento, y si de otra guisa se dieren que no valan ${ }^{58}$.

Desde entonces no habría otra causa metajurídica a alegar para entablar un pleito pleno de hidalguía que lo referente a la inmunidad fiscal: ya fuera por el hidalgo que debía incluso ser prendado, no esperarlo, sino ser efectivamente prendado y obligado a pechar para solicitar amparo al tribunal; como por parte de los concejos que si bien no estaban obligados a efectuar la prenda sí tenían como único motivo para acudir a los alcaldes de los Hijosdalgo a pleitear el que alguno de sus convecinos se negara abiertamente a contribuir alegando su nobleza. Así quedó todo hasta el final de los tiempos del pleito de hidalguía, hasta el XIX, y así se ligó este tipo de proceso para siempre al fisco y a lo él concerniente.

58 NR 2,11,8. 
Hasta aquí lo que dispone la pragmática sanción de 30 de mayo de 1492 dada en Córdoba por los Reyes Católicos. Pese a que ya se establecieron algunas de las intenciones, que respaldaban esta disposición regia al comentar el preámbulo de la misma, se debe hacer notar, de nuevo, la fecha de la ley y no sólo porque nazca a la vez que la Edad Moderna patria.

El 2 de enero de 1492 se rendía Granada, había terminado la Reconquista. Cinco meses después se promulga esta norma con valor y fuerza de ley hecha en Cortes. El final de la guerra de Granada, pese a que hubo ejércitos bien formados, ya fueran regios, señoriales o concejiles, y pese a que durante el conflicto final se fueran practicando usos y métodos que ya anunciaban las guerras modernas, fue sin duda el último gran conflicto medieval, se producían escarceos a la vieja usanza entre caballeros de ambos bandos, se armaban en el campo de batalla a nuevos equites, el honor medieval y las formas medievales todavía refulgían en sus últimos y postreros estertores peninsulares, y caballeros, como antaño, de toda Europa miraban - pensando en gloria, riqueza y cruzada - al último reducto musulmán de la Península Ibérica, y, casi sin pensarlo, muchos se plantaban en los reales cristianos a combatir por su Dios y por su honra y fama.

Es natural que la Corona, ante tamaño esfuerzo, tuviera todos los sentidos puestos en Granada, pero la capacidad de los Reyes Católicos, de sus consejeros, del Estado que nacía, era muy superior a la en principio aparente, y muestra de ello es la ley de Córdoba.

El Medievo terminaba, miles de personas dedicadas o prestas a la guerra por generaciones, al servicio de ciudades, señores, etc., empezaban a no poder entrar tal cual en los nuevos esquemas sociales y estatales sin correr graves riesgos, ante la misma nueva configuración estatal que iba imponiéndose: claro ejemplo lo tenemos en la caballería cuantiosa y villana. Y a esto, al fin de la Edad media y el comienzo de la Edad Moderna, junto a otras medidas políticas o sociales y económicas, responde la ley de Córdoba.

Pragmática de 1492 que asegura el control del reconocimiento de la hidalguía definitivamente a la Corona, única impartidora en el reino de mercedes y castigos, única capaz de crear y quitar noblezas, y única de reconocerlas con efectos generales o de no reconocerlas con iguales consecuencias. En resumen la Corona asume, controla y pergeña el reconocimiento de la calidad nobiliaria y utiliza esta ley para conseguirlo. Y en ella se encuentran dos grandes vertientes, ambas políticas y ambas jurídicas.

Sobran hidalgos tras Granada. Parece una exageración decirlo pero era así. Sobra gente rica que se ha ennoblecido durante las guerras civiles del tiempo de Enrique IV o después de ellas. Fueron útiles, tanto para el rey Enrique como para los Reyes Católicos, estos últimos los utilizaron incluso contra el propio Enrique y su hija. La llamada guerra de Portugal sirvió para que muchos que habían conseguido privilegios de hidalguía quedasen confirmados por tales al servir a los ene- 
migos de quien los había ennoblecido, pues a todos ellos confirmaron su nobleza los Reyes Católicos en el caso de guerrear junto a los nuevos monarcas. Sin contar a todos estos, la misma evolución social medieval había ya de por sí creado muchos nobles, ¿qué harían ahora?, tanto ricos como pobres.

El pleito de hidalguía era buen método para cercenar hidalguías, para rebajar números, y a la vez para seleccionar a los idóneos, independientemente de sangres. $Y$ además era buen camino para asegurarlos a todos a la Corona, como ya habían pretendido los Trastámara pasados. Así lo hicieron y lo consiguieron los Reyes Católicos en grandísima medida, casi definitiva. La ley por sí sola podía haber caído en el medio uso, si no se hubiera visto acompañada a la vez del fortalecimiento estatal.

El funcionamiento de unas Chancillerías, Ciudad Real y Valladolid, a pleno rendimiento, con graves problemas, pero a pleno rendimiento, acaparando sin cejar cada uno de los ámbitos de poder, político o jurisdiccional, que poseían, e incluso a veces más del que poseían, la estructura polisinodial de Consejos que iba arraigando, etc., permitieron a la pragmática de Córdoba de 1492 triunfar y ser piedra angular sobre la que los sucesivos soberanos fueran imponiendo modificaciones 0 perfeccionamientos, pero era indudable que había terminado el medievalismo en el pleito de hidalguía.

Recapitulando, la pragmática de Córdoba de los Reyes Católicos de 1492:

1. Recorta la influencia de la actividad concejil en el proceso de hidalguía al potenciar la figura de los procuradores fiscales. Lo que producirá primero por analogía y posteriormente por ley, que se lleve el pleito hasta las últimas instancias, revista, antes de que en él recaiga la calidad de pasado en cosa juzgada.

2. Relativiza la importancia de las decisiones de los alcaldes de los Hijosdalgo y notario al reforzar la intervención en apelación o suplicación de los oidores en estos temas.

3. Restringe sólo a una, las causas metajurídicas que pueden dar lugar a un litigio de estas características, que lo será en adelante sólo la inmunidad fiscal avasallada o, su contrario, la obligación tributaria no cumplida, mediando la prenda como evidencia de ambas posibilidades.

4. Establece la posibilidad secundum legem de contender sólo por la posesión o por la posesión y la propiedad, pudiéndose apartar de la propiedad, el hidalgo, si así lo considera oportuno.

5. Conociendo que es la prueba solvente por excelencia en esa época la testifical, la probanza, y conociendo la imposibilidad de acudir a otra lo suficientemente fehaciente, la pragmática establece y fija dos variantes con respecto a la prueba: la primera atiende tanto a casos en los que hay 
confrontación como a los que no la hay, y no es otra que los testigos puedan deponer de oídas del abuelo, cuando éste vivió en fechas tan remotas que no hay posibilidad de que ningún vivo lo conociese personalmente, y que tal testimonio surta los mismos efectos y seguridades probatorias que si sí se hubiera dado el tal conocimiento. Igualmente y por lo que se refiere al aparato probatorio faculta a aquél que se dice hidalgo a que sin pleito por medio, pueda asegurar la pervivencia de su nobleza para el Derecho, lo que le será muy útil a él y a sus sucesores si alguna vez se deben defender ante la Chancillería. Y esto lo admite la ley cuando el hidalgo solicita y realiza una información de su hidalguía ad perpetuam rei memoriam.

6. Plasma en la letra de la norma -más allá de disquisiciones de teóricos anteriores y sobre todo posteriores - lo que se entiende para el Derecho castellano, por hidalgo notorio de solar conocido. Que no es otro que el que puede demostrar de sí, su padre y abuelo haber estado pacíficamente en opinión y reputación de hombres hijosdalgo en todas las localidades donde han vivido y por un espacio de veinte años o superior a éste, gracias a lo cual siempre gozaron de las franquezas, preeminencias y obligaciones, igualmente que los otros hidalgos de Castilla.

7. Establece de forma general otro precedente, el de la revisión de sentencias y privilegios nobiliarios que pudieran haber sido establecidos contra Derecho $^{59}$.

8. La pragmática ya no deja por ley opción a otras prácticas y a que éstas tengan efectos reales: «Y de otra guisa que ninguno de aquí adelante pueda ser dado por hijodalgo en posesión ni en propiedad, ni le sea dada carta executoria ni privilegio. $Y$ si de hecho fuere dado y pronunciado por hijodalgo, mandamos que la sentencia, ni el privilegio, ni la executoria que de ello se diere no vala» ${ }^{60}$.

La ley cordobesa plantea temas a nivel nobiliario tan destacados como lo que es para el proceso un hidalgo notorio, la figura revalorizada de fiscal y oidores, la revisión de sentencias, los medios de prueba, etc., aspectos que pervivirán a lo lar-

59 De que el mandato de 1492 de revisar las hidalguías concedidas por Enrique IV se llevó a cabo hay bastantes evidencias, y esto se debió entre otras cosas a que el interés de los concejos era evidente a la hora de evitar nuevas o antiguas noblezas. Aunque, también hay que precisar la dicha revisión y sus efectos que deben ser cuantificados y analizados. Muestra de que su cumplimiento se mantenía es que los Reyes Católicos en una real provisión ordenando una receptoría, que está fechada en 24 de enero de 1503, daban cuenta que el concejo de la villa de Herrera decía que su vecino Hernando de Frías era pechero y debía pechar pese a que decía tener privilegio de hidalguía dado por Enrique IV, cosa que por otra parte era la defensa del Frías que se decía ser «ome fijodalgo por virtud de un privilegio del señor Rey don Enrique, nuestro hermano... que fue dado y conçedido a su padre del dicho Hernando de Frías». En consecuencia de todo ello el presidente y oidores de la Chancillería, todavía con sede en Ciudad Real, habían recibido a las partes a prueba para ver lo del privilegio y cuál de las partes tenía razón según Derecho, debiendo concejo e hidalgo acudir a la Corte en término de 50 días, ARChG, Registro del Sello, 5.043 .

60 NR 2,11,8. 
go de los siglos, haciendo a la ley de Córdoba piedra angular de todo lo que vendría después. $Y$ hay que decir, por lo que afecta a su cumplimiento, que casi inmediatamente desde su promulgación fue obedecida y cumplida en las Chancillerías, véase el siguiente ejemplo: una ejecutoria dada en Ciudad Real en 1494. En ella se dice:

El qual dicho pleito fue sobre rasón de demanda que por parte del dicho Rodrigo Yáñez de Santacrus fue presentada ante los dichos nuestros alcaldes de los Fijosdalgo e notario del dicho Reino de Toledo contra el dicho nuestro procurador fiscal en nonbre e contra el dicho Conçejo (...) de Almedina (...) a dos días del mes de dizienbre del año del nasçimiento de nuestro Salvador Ihesu Christo de mil e quatroçientos e noventa e tres años, por la qual entre otras cosas dixo que seyendo segund que hera el dicho Rodrigo Yáñez de Santacrus, su parte, ome fijodalgo notorio de padre e de agüelo e de solar conosçido e de vengar quinientos sueldos segund fuero de Castilla (...) E de poco tienpo a aquella parte el dicho Conçejo e omes buenos, partes contrarias, ynjusta e no devidamente e por fuerça e contra su voluntad del dicho su parte le avían puesto en los padrones de los pecheros e le avían prendado por los pechos de los omes buenos pecheros de la dicha villa (...) Por ende que les pedía a los dichos nuestros alcaldes e notario que mandasen faser e fasiesen al dicho su parte e a él en su nonbre conplimiento de justizia de las dichas partes contrarias sobre todo los susodicho. E fasiéndolo por sentencia difinitiba, judgando pronunçiasen e declarasen al susodicho ser e ver provado, asy segund e como por él como de suso fuera dicho e provado, el dicho su parte ser ome fijodalgo notorio de padre e de agüelo e de solar conosçido e aver estado e estar en tal posesyón. E asy proçediendo (...) que le bolbiesen todas las dichas sus prendas que le avían tomado e prendado por los dichos pechos de pecheros e tales e tan buenas como heran e estavan al tienpo e quando ge las tomaron e prendaron o por ellas su justo valor e preçio, para lo qual todo ynploro su ofiçio de los dichos nuestros alcaldes de los Fijosdalgo e notario y pidió e protestó las costas e petisión de suspender el petitorio e que fuese proçedido en el posesorio, e que desde estonçes le suspendía sy nesçesario fuera y al dicho su parte conviniese e non en otra manera ${ }^{61}$.

La demanda aquí transcrita, mejor aquí resumida, pues al ser sacada de la ejecutoria no es la original que en su momento se presentara sino su relato y sin entrar en las formalidades que exige el Derecho en ese momento para las demandas en general, reúne las exigencias de la pragmática cordobesa: exigencia de ser declarado hijodalgo notorio, por serlo el demandante de sí, su padre y abuelo, y haber estado en pacífico goce de ello. Ser la causa de esta petición el que se le había prendado por el concejo de su localidad, avasallando los privilegios inherentes a su posesión de hidalguía y por último suspensión del petitorio de la propiedad mientras al hidalgo le conviniese. Sin olvidar que se está recurriendo en primera instancia y como caso de Corte, ante la Sala de los Hijosdalgo.

El pleito continuó bajo las reglas de la ley de Córdoba de 1492 y de las leyes que sobre esta materia disponían y que eran anteriores a las de los Reyes Católicos y que se encontraban todavía vigentes. Así hubo el correspondiente escrito de

61 ARChG, Hidalguía, Caja 46, pz. 2. 
contestación a la demanda por parte del Concejo de Almedina, así como del fiscal del Rey, y vistas excepciones y alegaciones de ambas partes se dio el pleito por concluso por sentencia interlocutoria de los alcaldes de los Hijosdalgo y notario de Toledo, por la que se recibía a las partes a prueba.

Probanzas de testigos, la usual en exclusiva por aquellas fechas. Por si hubiese pocas coincidencias, el concejo además terminó retirándose del pleito, por lo que en virtud de las leyes regias y de la de Córdoba, el fiscal en solitario siguió el proceso, lo que hizo que, al perder el fiscal, finalmente, el pleito y que fuera declarada la parte hidalga por tal, tuviese el concejo y los hombres buenos de él, que afrontar las consecuencias económicas en virtud de la actitud que había guardado el municipio, como así dice la sentencia definitiva dada por los alcaldes y notario en Ciudad Real el 26 de mayo de 1494 y de la que aquí se extracta esa condenación económica:

E condenaron al dicho Conçejo, alcaldes, regidores, ofiçiales e omes buenos de la dicha villa de Almedyna en las costas derechas fechas por el dicho Fernand Gonçales de Santacrús e por su parte en en seguimiento del dicho pleyto (...) e tasaron con juramento de la parte del dicho Rodrigo Yáñez de Santacrús en dies mil e ochoçientos quarenta çinco maravedís de la moneda usual segund e más largamente las dichas costas están escriptas e tasadas por menudo en el proçeso del dicho pleyto62.

Seguimiento exacto de la pragmática de Córdoba de 1492 y en virtud de ella todavía sólo una sentencia definitiva y dada en primera instancia por los alcaldes de los Hijosdalgo, aspecto éste que con el tiempo sería impensable ya que todos los procesos de hidalguía llegarían a contar con tres sentencias hasta el grado de revista. Como se ha mencionado esto último ocurriría primero por analogía o por la simple actitud pertinaz de las partes, para más tarde terminar imponiéndolo la ley expresamente, pero no la de Córdoba que sólo exige en realidad que se apele cuando se trataren de las sentencias mandadas revisar, y la del pleito de Santacruz no era una de ellas por lo que bien podía sustanciarse sólo con la de los alcaldes de los Hijosdalgo y notario de Toledo.

De igual forma y para finalizar el análisis de la pragmática cordobesa de 30 de mayo de 1492, se debe resaltar de nuevo la importancia de que ya la única causa originaria de confrontación es la hacendística, y cómo esta ley, que exigía la prenda como evidencia, cuando se trata de la actitud de los concejos se interpreta con amplitud. Como por ejemplo lo evidencia la actuación del concejo de la villa de Campanario, que sin previo prendamiento de bienes de los hidalgos, se decide a reclamar la pechería de los que se decían hidalgos en su localidad.

Doña Juana e don Carlos, su hijo, por la graçia de Dios, Reyna e Rey de Castilla..., a vos Rodrigo Pérez e Françisco Benites..., vezinos del lugar del Canpanario, salud e graçia. Sépades que en la nuestra Corte e Chançillería que está e re-

62 Idem. 
side en la çibdad de Granada, ante los nuestros alcaldes de los Hijosdalgo e notario de la Provinçia de León paresçió la parte del dicho Conçejo e omes buenos de ese dicho logar del Canpanario e nos hiço relaçión por su petiçión que ante ellos presentó diziendo que demandava ante los nuestros alcaldes e notario a vos los susodichos e dezía que vosotros e cada uno de vos seyendo como soys pecheros llanos y obligados a pechar..., e seyendo como soys hijos e nietos e deçendientes de omes buenos pecheros... E agora nuevamente de poco tienpo a esta parte avéys querido substraer e subtraéys de pechar..., diziendo de vos hijosdalgo... Porque pedía a los dichos nuestros alcaldes e notario hiziesen justizia al dicho Conçejo, justiçia e omes buenos de ese dicho lugar, su parte sobre lo susodicho... e por el remedio que más aprovechase declarásenvos, los susodichos, por tales pecheros... e a que pagásedes e restituyésedes a los dichos sus partes todos los maravedís e cantidades... de que ansy avéys subtradydo e escusado de pechar ${ }^{63}$.

Antaño el concejo hubiese, si podía en virtud de su fuerza de hecho, prendado directamente a los opositores, por ejemplo basándose en la pragmática enriqueña, pero no siempre podía y aquí tenía en la Corona un valedor que con su fuerza legal y también de hecho lo secundase y amparase frente a los que se decían hidalgos, lo fuesen o no, y esto gracias a una interpretación laxa de la pragmática cordobesa de 1492.

\section{ALGUNAS CONCLUSIONES}

Han sido vistas y comentadas, así como ejemplificadas, las principales normas medievales que fueran recopiladas en tiempos de Felipe II y que jugaron un papel muy importante en su tiempo, cuando fueron creadas, no sólo por ser recopiladas después, que también, sino que por su propia valía conformaron desde fines del siglo XV en adelante unos pilares decisivos sobre los que construir el pleito de hidalguía de la Edad Moderna. Relevantes, pues, tanto en el Medievo como en la Edad Moderna.

Cabe preguntarse por cómo afectaron todas ellas, en su evolución a tres de sus principales sujetos: creadores, sufridores y usuarios de ellas.

1. Para la nobleza, es evidente que para la gran nobleza no, pero sí para el resto, que cuantitativamente era mucho más numerosa como por todos es sabido, lo que convierte lo cuantitativo en también cualitativo, los pleitos de hidalguía conformados desde los Trastámara supusieron ventajas e inconvenientes. Entre lo último sobresale que toda esta legislación está incardinada en el paso bajomedieval del uso feudal y privado de la nobleza jurídica hacia la esfera del ámbito público jurídico, más restrictiva. Y como tal representan un recorte, mejor encauzamientos obligatorios, que como es lógico se intentaron sortear y se sortearon a veces, para gozar de la hidal-

${ }^{63}$ Se dio la real provisión emplazando a los hidalgos de Campanario a 13 de marzo de 1519, ARChG, Hidalguía, Caja 220, pz. 15. 
guía, de qué hidalguía, y cómo defenderla y gozarla según Derecho. Desde este punto de vista supone pues, esta legislación que se presenta unas veces protectora única de la nobleza y en otras de los concejos, al cabo siempre de la Justicia - regia no se olvide - digo que supone una amenaza que se convierte cada vez más en real conforme avanza el poder de la Monarquía. Lo que no quiere decir que la mayoría de los nobles soportaran pleitos de hidalguía de jurisdicción regia, no local, pues esa justicia no ha sido aquí más que muestra de pervivencias, pero que sí muchos los sufrieron, sobre todo desde 1492 hasta mediados del siglo XVII. De hecho varios mandatos de tiempos de Felipe IV ante la belicosidad de su reinado y la renuencia de los hidalgos a participar en las guerras, hicieron legalmente irrenunciable permanente o temporalmente a la hidalguía, bajo graves penas, pues no se alistaban los hidalgos en los llamamientos regios. Exactamente lo contrario a lo visto en el Fuero Viejo y a la importancia que representa éste en cuanto a muestra del valor de la autonomía de la voluntad en el goce y ejercicio nobiliario. Lo que no implica que los nobles alto y bajomedievales no tuvieran obligaciones públicas forzosas, pero el mismo Fuero Juzgo y muchos fueros y leyes hablan por ejemplo de los que no acuden a la hueste debiendo hacerlo o la abandonan para sus asuntos particulares... Para la nobleza, en consecuencia, la legislación vista posee aspectos negativos y, con el tiempo, sobre todo económicos, no sólo de las cargas debidas a terceros, sino de los mismos gastos que suponían afrontar estos litigios. Pero también los hubo positivos. La sentencias y ejecutorias ganadas suponían a sus poseedores y más a sus descendientes una documentación relevante con la que apuntalar su nobleza y para disfrutar de ella ${ }^{64}$, tanto para la Baja Edad Media como para la Edad Moderna, de ahí las falsificaciones $\mathrm{y}$, cuando no, recursos a otros instrumentos para o bien hacerlos pasar por los otros o para, pareciéndose, aunque sólo fuese formalmente, agarrarse a ellos para mantenerse nobles o hacerse ${ }^{65}$. Sin olvi-

64 Por lo que respecta a la cuestión meramente fiscal, recordemos que si bien se devalúa en importancia económica la exención conforme avanza el tiempo, existen otra serie de servicios y gravámenes, ya no fiscales, pero sí debidos a la Monarquía y a sus instituciones, como el repartimiento de soldados y huéspedes, de bagajes, mulas, etc., no menos molestos e importantes que los otros —recuérdese el Alcalde de Zalamea y lo que le vino de recibir huéspedes- para los que era buen escudo jurídico y fáctico una ejecutoria o una real provisión. Sin olvidar que en muchos pleitos de mitad de oficios las partes contrarias exigen que los hidalgos para ser tenidos como parte, si no todos, sí algunos puedan demostrar su notoriedad y nobleza a través de estos instrumentos, de sentencias y ejecutorias, pues en caso contrario amenazan los oligarcas pecheros con no tenerlos por parte y prendarlos a todos.

65 Son varios los casos encontrados sobre este tipo de falsificaciones en el siglo XVI reinando Felipe II, la Chancillería de Valladolid acudió al Rey pues habían detectado a un escribano que había confeccionado una ejecutoria falsa para terceros. Solicitaban la entrega del huído, pues aunque se les había dado la ejecutoria, éste estaba en un monasterio y en sagrado y no querían dar los religiosos al criminal. Luego las falsificaciones existían, pero cuando se conocían se perseguían como consta de la siguiente pregunta de un interrogatorio del fiscal granadino doctor Silvente y el concejo de Estepa, estando ya el pleito de hidalguía ante el presidente y oidores, en 1579: «Si saben que el dicho Luys de Sexas, difunto, y Alonso de Sexas, su ermano, tubieron en la dicha villa de Estepa el dicho prebilegio (de caballero pardo) y cautelosamente, los susodichos y otras personas por ellos, lo presentaron en cabildo y conçejo de 
dar que estos instrumentos, desgajados los nobles de los entramados feudovasalláticos y dedicados la mayoría a oficios no propios de ellos, en la ideología oficial de antaño y de agora, pues ni creo en tipologías fisonómicas hidalgas ni en generalizaciones del escudero del Lazarillo, prima el instinto de supervivencia frente a lo último y no sólo en Asturias: de uno y de su familia. Digo que en esos casos las ejecutorias les permitían seguir siendo nobles, jurídicamente, y sentirse tales y aparentarlo cuando quisieren, y además, quién sabe, quizá sus descendientes, con mayor economía, dejasen esos oficios. Se trata pues de cierto aburguesamiento vital, más para la Edad Moderna que para la Medieval, del hidalgo, que en realidad no traiciona nada: vive ${ }^{66}$. Ya lo denota Cervantes, esta situación, muy graciosa, cruel e irónicamente, con las siguientes palabras en su Coloquio de Perros, cuando se arma trajín y lío entre el alguacil, la Colindres y su acompañante, y el representante de la ley hace salir a la huéspeda de la casa, que airada dijo: "Que bien conozco a la señora Colindres y sé que ha muchos meses que es su cobertor el señor alguacil. Y no hagan que me aclare más sino vuélvase el dinero a este señor, y quedemos todos por buenos. Porque yo soy mujer honrada, y tengo mi marido con su carta de ejecutoria, y con a perpenam rei de memoria, con sus colgaderos de plomo. Dios sea loado, y hago este oficio muy limpiamente y sin daño de barras ${ }^{67}$.

2. Para los concejos y para los pecheros, los pleitos de hidalguía que se configuran a través de las leyes medievales vistas, tuvieron sus pros y sus contras igualmente. Los concejos que de sí, habían entendido de estos pleitos a través de sus justicias o por «manu militari» si era necesario, sufrieron paulatinamente la pérdida de competencia jurisdiccional primero y por lo general, y, segundo, ya en la Edad Moderna, la competencia de facto. Siempre se resistieron a ello, incluso oficiales que dependían directamente del rey como los corregidores y alcaldes mayores, ya se ha visto, pretendieron seguir conociendo de los pleitos plenos de hidalguía en Castilla hasta incluso bien entrado Felipe II —recuérdese el caso de Córdoba. Que todas estas leyes medievales y la actividad de los reyes y gobernantes modernos fue hasta cierto punto eficaz se ha comprobado general y particularmente, pero también lo evidencia el que los concejos y los linajes villanos o nobles, a los que representaban, seguirán intentando recuperarla de una u otra for-

\footnotetext{
la dicha villa, diçiendo ser executoria litigada en contraditorio juyzio e pretendieron ser libres y esentos de los pechos y serbiçios de pecheros y gozar de las inmunidades y franquezas de los hijosdalgo", ARChG, Probanzas, Caja 9138.

66 Ya lo propuse en mi primera y tosca comunicación que presenté a un congreso, sin mucho éxito por otra parte, pues parece interpretase por otros de ella, que contradice el ambiente aristocrático de la Edad Moderna, y no es así. DÍAZ DE LA GUARDIA Y LÓPEZ, L.: «Aburguesamiento de la nobleza media y baja en Castilla: los pleitos de hidalguía", en ENCISO RECIO, L.M. (Coord.): La burguesía española en la Edad Moderna. Valladolid, Universidad de Valladolid, 1996, Volumen I, págs. 517-531.

67 CERVANTES SAAVEDRA, M. de.: «Coloquio de perros», en Novelas Ejemplares. Prólogo y notas de Francisco Alonso. Madrid, EDAF, 1996, págs. 514-515.
} 
ma durante todo el siglo XVI a través de las Cortes, aunque no se hizo novedad en ello, por ejemplo pretendiendo conocer de los casos de posesión -la mayoría, pues los hidalgos suspendían el petitorio de la propiedad generalmente, aunque algunos después visto que el pleito se decantara en su favor volvieran a pedir la dicha propiedad ${ }^{68}$. Por otra parte muchos erarios municipales se vieron muy necesitados o bien por pechar a muchos que se decían hidalgos y tener que soportar los pleitos de todos a la vez o bien por surgir algún pleito con persona muy destacada que podía con buenos letrados y asesores dilatar el litigio cuanto pudiese, de ello hay constancia ante las Chancillerías y ante el Consejo a través de consultas. Por último, en caso de hidalgos vencedores, los concejos tenían que acatar la superioridad social y las inmunidades de sus contrarios, de sus enemigos, ambas contradichas y no deseadas, pero mandadas respetar por el rey mismo. En cuanto a los pros residen en diferentes puntos. Por un lado, los concejos desde la Edad Media hasta el fin del Antiguo Régimen tuvieron en sus manos otras medidas, legítimas y en las que eran competentes, para o hacer pecheros o hacer nobles, dependiendo de las circunstancias y deseos políticos, a quienes quiseran. Por ejemplo a través de los repartimientos o de la ocupación de cargos reservados a nobles, etc., así como en sus posiciones favorables y fraudulentas para amañar testimonios escritos o probanzas, ya fueran propias o de los escribanos y párrocos, pongo por caso. Esto es sabido y demostrado ${ }^{69}$. Por otro lado y como es sabido siempre go-

68 Dice la petición XXVI de las Cortes de Valladolid de 1537: «Otrosy, dezimos que por ynsperiençia se ve en muchos lugares destos reynos que muchos que son hijosdalgo, conoçidos por ser personas pobres, quando son enpadronados, como el conoçimiento de su justiçia esté cometido a los alcaldes de los Hijosdalgo que resyden en las Chançillerías, no pueden seguir justiçia por su pobreza, pagan y asy quedan pecheros ellos y sus desçendientes, suplicamos a Vuestra Magestad, que los que provaren estar en posesyón de hijosdalgo, de ellos y de sus padres, a lo menos por espaçio de veynte años, el conoçimiento de esto se remita a los corregidores y juezes ordinarios de estos regnos en quanto toca a la posesyón. A esto vos respondemos que se guarden las leyes de nuestros reynos que çerca de esto disponen", Cortes de Castilla, Cortes de Valladolid de 1537, Ordenamiento.

69 No obstante cuando no había común asenso entre las oligarquías la cosa no era tan fácil. Alcaraz es un ejemplo, véase la siguiente real provisión de emplazamiento: «Don Fernando e doña Ysabel, etc, a vos Juan Romero del Olmo e Antón de Alarcón e Anbrosyo de Llerena e Leonor Díez de Vença e Alonso Muñoz, el que vino de Villanueva e la muger de Juan Romero, fijo de Juan Frutoso, e Peralta, yerno de Fernando de Segura, e Tomás de Avilés e Pedro el romo, e los fijos de Sancho de Arenas e Gonçalo de Alcaraz, fijo de Pedro Fernández, e Martín de Alcalá, e la de Alonso de Alcalá e Pedro González de la Dueña e la de Pedro de Alcalá e Fernando de Alcalá, su fijo, e Juan de Alcalá, su hermano, e Diego Ruyz de Alcalá e la de Sancho de Alcalá e Juan de Pinilla e Christóval Muñoz e la de Pedro de Reoliz e Garavito e Juan de Buytrago e Françisco de Funes e Pedro de Buytrago e la de Juan Gonzáles de la Puerta Granada, e Gonçalo Rodrígues de Molina e Françisco de Buytrago e Juan Romero, yerno de la de Sancho Barvero, e Diego de Buytrago e Gonçalo de Millán e Girónimo de Segura e Garçía Rodrígues de Molina, e los fijos de Juan Muñoz de la segunda muger e Antón Pérez de Coca e Rodrigo Mexía e Juan de Reoliz e Pedro de Reoliz e Diego de Vandelvira e Juan de Vandelvira e su madre Juan de Castro e la de Pero Gonzáles de la Dueña, e Juan de la Dueña e Calderón, yerno de Pero Gonzáles de la Dueña e Juan de Peralta, veçino de Bogarra e ofiçio aserrador, e Salazar de Lezuza e su madre e los fijos de Sancho de Almansa, veçinos de Lezuza, e los fijos de Bartolomé Sánches de Almansa e Juan de Mesto, e Pedro de Mesto, hijos de Sancho de Mesto, e Juan Muñoz, yerno de Cabrejano, e los bienes de Alonso Muñoz de Lictor, e Alonso de Chinchilla, fijo de Pedro de Chinchilla, e Pedro de Soto e la de Juan Pruero e sus fijos, e Pedro de Çepeda e la de Pedro de Vera e Christóval de Vera, su hijo, e los hijos de 
zaron de prevalencia, pese a Felipe $\mathrm{V}$, en la cuestión no litigiosa de recibimientos y continuidades lo que les facultó mucho para seguir siendo árbitros en última instancia.

3. Para finalizar, la Monarquía, la hacedora de todas estas leyes. La Corona consiguió para sí primero legalmente y, después, mayoritariamente de hecho, que el pleito pleno de hidalguía no sólo fuese visto como caso de Corte sino que, también, desde los Reyes Católicos y sobre todo con Carlos I y Felipe II que unas Chancillerías fuertes lo controlaran, pese a todas las excepciones que se puedan alegar. De este modo esa evolución de sometimiento al poder regio que suponen todas estas leyes bajomedievales estudiadas, independientemente del fruto que dieran en sus tiempos, sí consiguieron la finalidad última pretendida por todos los monarcas: ver en exclusiva conforme a Derecho, de estos procesos. Claro está que no se consiguió en la práctica de manera absoluta, que quedaron resquicios a veces muy grandes por donde escapar a su control la última decisión sobre quién era y quién no era hidalgo. Pero en conjunto y para Castilla se puede decir que sometieron en parte a los concejos y a los nobles a sus leyes, no sólo ya con estas medievales sino también con las modernas. No obstante siempre hubo la preocupación regia y del Reino, porque los pleitos se hicieran concienzudamente, para eliminar cuantos más hidalgos - ciertos 0 no-mejor y en las pruebas, además de en otras perspectivas jurídicas, no consiguieron nunca la perfección, pese a establecer cuantas medidas su-

Garçía de Segura de la segunda muger, e Marí Vasques, e Pedro de Arixita, e Pedro de Arriaga e Estevan de Mendaron e Petre Sánchez e la de Alonso de Orçera e su nieto, e Pero Ximénez Morejón, e la de Alonso de Almansa, fija de Gonçalo de Vargas e Diego Viscayno e su fijo e Pedro del Val e Pedro Ximénes Tyscarejo e Pedro Ximénes el moço e la // cana vieja, e Tristán de Vallesteros e Fernando de Orçera, Fernando de Salazar e sus hijos e su hijo cuñado de Montalegre e Gonçalo Muñoz de Bigarra e Antón Muñoz e Juan Muñoz, sus hermanos, e la de Diego Mexía de la de Alonso de Pinilla, e Sancho de Pinilla, Bartolomé Muñoz e la de Pedro de Alcalá, fijo de Fernando de Alcalá e Gonçalo de Montiel el cabiztuerto e Fernando de Chinchilla e Fernando de Montiel e Leonor López e Alonso Çedrán e los fijos de Pedro de Montiel e la de Fernánd Sánchez de Montiel, hermano de Alonso Cedrán e la de Pedro Díaz de Toledo e sus fijos, e Fernando Algasyl, fijo de Pero Algasyl e Sancho Sánchez de Montiel e Sancho de Montiel el largo, e los nietos de Sancho de Toledo e Juan de Bustamente e Juan de Claramonte, yerno de la de Sancho Barvero, e los fijos de Fernando de Segura e Alonso Algasyl, fijo de Pero Algazil, e Fernando de Segura, fijo de Garçía de Segura, e sus hermanos Garçía de Segura e Alonso de Segura e María de Requa, muger de Andrés de Segura, e la del liçençiado Ruy Díaz e Christóval de Arroyo e Juan de Arroyo e los fijos de Pero Díaz de Montoro, nietos de Alonso Díaz, e Juan Gonçález de Viscaya e Pedro de Medyna, vesynos de la çibdad de Alcaráz, salud e graçia. Sepades que en la nuestra Corte e Chançillería que resyde en Çibdad Real ante los nuestros alcaldes de los Fijosdalgo e notario de Toledo, pareçieron el bachiller Lope de Lodio, nuestro procurador fiscal, en nuestro nonbre e la parte del común e omes buenos pecheros de la dicha çibdad de Alcaráz e presentaron ante ellos una petiçión por la qual dixeron que les fasýan saber que syendo com,o ferades vos los sobredichos pecheros llanos, fijos e nietos de pecheros e obligados a pechar e contribuyr en los pechos e tributos tocantes a pecheros que vos agora, nuevamente, de poco tienpo a esta parte vos queredes subtraer e subtraydes de pechar... Dada en Çibdad Real a XXIIII días de otubre de 1503 años», ARChG, Hidalguías, Caja 5074, pz.24. El concejo era partidario de ennoblecerlos y ponía todos los impedimentos, pero algún grupo poderoso se oponía y a través del síndico las gestiones son muchas para atacar a la oligarquía local enemiga y duran buena parte del siglo XVI cuando menos, por cierto siempre recibió el apoyo de la Chancillería. 
pieron y tuvieron a bien poner ${ }^{70}$. No obstante y reiterando, si bien a todos los Monarcas les interesó que los pleitos cumpliesen todos los requisitos jurídicos y fácticos que permitiesen y la pragmática de Córdoba, última ley aquí estudiada, lo evidencia, lo cierto es que de la legislación medieval recopilada en 1567 lo que muestra, sobre todas las cosas, es el deseo y la intención de que el pleito quedara bajo manos de la Monarquía, bajo la potestad real absoluta, y en eso, creo, sí hubo un éxito comprobable, aunque, como ya he dicho, no absoluto.

Ya establecí que este texto no era acomodaticio con la común opinión historiográfica, sino que busca y buscaba conseguir nuevas perspectivas, nuevas propuestas, creo que aunque discutibles, documentadas. Queda seguir y no dar a este proceso que tanta importancia, más social que real, tuvo, como un simple paso de fácil resolución para los aspirantes a ser reconocida su hidalguía - fuera cierta o no, ahí por ahora no entro-, el sufrimiento era grande: sufrimiento económico, sufrimiento social, sufrimiento personal ${ }^{71}$. $Y$ todo aunque se fuere un falsario, pero es

70 «A Su Magestad se ha hecho relaçión de la mucha desorden que ay en las Chancillerías en librar cartas de hidalguía con mucha facilidad. Y que es cosa que se podría mandar mirar y proceder con recato, por el perjuyzio que resulta o a los derechos de Su Magestad o al estado de los Pecheros, y encargar a los presidentes de las Chancillerías que lo encomienden mucho a los fiscales y juezes. Y dize Su Magestad que vuestra merçed vea como avrá de haber y si será por çédulas suyas despachadas por la Cámara o aquí señaladas por vuestra merçed o si yrán por el Consejo Real, porque de una manera o de otra parece a Su Magestad necesario que se remedie y se ordene bien. Dios guarde a vuestra merced muchos años, en Valladolid a 23 de agosto de 1592" Lo que se acaba de leer es una carta remitida por el secretario del Consejo, Jerónimo Gassol, al licenciado Guardiola. El licenciado dio su opinión: «parece que será mejor despachar estas çédulas por el Consejo, especialmente porque ahí se ha tratado de este particular muchas veces". La carta y la respuesta se pasaron a consulta regia, el gran Felipe II no quedó muy contento de la decisión y creyó oportuno seguir estudiando semejante problemática por lo que de su puño y letra, como acostumbraba, zanjó momentáneamente el tema: «esta consulta y las dos que se siguen se vean en la Junta de Palencia». Era fines del reinado Felipe II y sin embargo a cien años de la pragmática cordobesa de 1492 de los Reyes Católicos, su bisnieto y su gobierno seguían preocupados por los pleitos de hidalguía, Instituto de Valencia de Don Juan, Envíos, Envío 62, n. ${ }^{\circ} 160$.

71 Las probanzas de los concejos y fiscales, que se realizaron y en todas las instancias eran verdaderamente dolorosas y pese al juramento de secreto de los testigos no creo que quedaran sólo en la Sala y Tribunal. Un ejemplo y no de los más fuertes es el siguiente en el que se han extractado las preguntas del interrogatorio realizado por real provisión dada por los alcaldes de los Hijosdalgo el 31 de octubre de 1578 dirigida a Pedro de Yepes escribano receptor, notificándole existir pleito de hidalguía recibido a prueba entre Rodrigo de Sandoval, vecino de la villa de Ardales, y de la otra parte el concejo de Ardales y el doctor Marcos Caro, fiscal de S.M. Pregunta II: «Yten si saven que el dicho Rodrigo de Sandoval, que litiga y su padre y abuelo y parientes por línia de varón an sido y son honbres llanos pecheros y como tales an pechado en los pechos de pecheros y en esta posesión y reputaçión estuvieron y an estado en la dicha çiudad de Antequera, donde fueron vezinos de uno, diez, veynte, quarenta año y tanto tienpo a esta parte que memoria de hombres no es en contrario, digan lo que saven y an oydo dezir». Pregunta III: «Ytem, si saben que el dicho Gutierre de Sandoval, padre del dicho Rodrigo de Sandobal que litiga, fue hombre que tubo ofiçios baxos, como fue enpedrador de calles y casas y ofiçial de albañir y a estos ocupaba su bida y los uso mucho tienpo, mientra fue vezino e bibió en la çibdad de Antequera y lo husa al presente un hijo uyo que se llama Martín de Sandobal, hermano del que litiga, el qual es havido y tenido por honbre llano pechero». Pregunta IV: «Sy saben que todo el tienpo que fue veçino y estubo en la çibdad de Antequera el dicho Gutierre Sandoval, padre del dicho Rodrigo de Sandoval, que litiga, husó el dicho ofiçio de enpedrador y sienpre a la continua fue tenido y abido por honbre llano pechero e nunca le oyeron los testigos dezir ni mentar ni jatarse que fuese hidalgo, ni le bieron juntarse en juntas de hidalgos, porque si lo fuera se jatara de ello como otros hidalgos de la çibdad de Antequera e se juntaran en jun- 
que estamos hablando de la justicia de los hombres y no de la justicia angelical, y la primera se basa en las cosas de los hombres y no en las de la divinidad. Así que lo fundamental que hay que tener siempre presente es que en estos pleitos, como ahora, lo que se trataba por ambas partes era ganar, no conseguir siempre verdadera justicia. Y la justicia de los hombres, en ocasiones, cambia realidades y condiciones sociales, económicas y de todo tipo. Ayer y hoy.

\footnotetext{
tas de ellos como era dicho e los suyos lo bieron por el mucho trato e conoçimiento que con el dicho Gutierre de Sandoval tuvieron». Pregunta V: "Yten si saben que el dicho Rodrigo de Sandoval que litiga, es moço soltero por casar y no tiene casa conosçida si no es la de su madre que al presente es biuda. $\mathrm{Y}$ el susodicho es ofiçial de sastre e pocas bezes asiste en la çibdad de Antequera y a esta causa no es conosçido porque se ba fuera a trabajar para el dicho ofiçio de sastre donde halla. Y a esta causa el susodicho no puede aver adquerido posesión de hidalguía, ni la a tenido, porque lo más de tienpo como está dicho no está ni asiste en la çibdad de Antequera». Pregunta VI: «Yten, si saben que el dicho Gutierre de Sandobal, padre del que litiga, estubo preso en la cárzel pública de la dicha çibdad de Antequera y de allí fue sacado a la verguença, cavallero en un asno y lo traxeron por las calles públicas de la dicha çiudad de Antequera e juntamente lo echaron a galeras del reino por delictos que cometió en la dicha çibdad de Antequera». Pregunta VII: «Sy saben e an oydo dezir que quando se perdieron las galeras de don Juan de Mendoça en la Herradura, entre los galeotes que allí se escaparon se abía escapado entre ellos el dicho Gutierre de Sandoval y se avía quedado en un puerto de los de mar y estubo en Almería en casa de don Luis de Rojas, arçediano de la dicha çibdad de Almería». Pregunta VIII: «Yten si saben que si la parte contraria y su padre e abuelo y antepasados, parientes por línea reta de varón, en algún tienpo dexaron de pechar rezibir huespedes, salir a los alardes y a lo que los demás honbres llanos pecheros tienen obligazión de hazer sería y fue por ser muy pobres y aber bibido en ofiçios muy baxos e biles», ARChG, Probanzas, Caja 9140.
} 